Prepared in cooperation with the National Park Service

\title{
Assessment of Ambystomatid Salamander Populations and Their Breeding Habitats in the Delaware Water Gap National Recreation Area
}

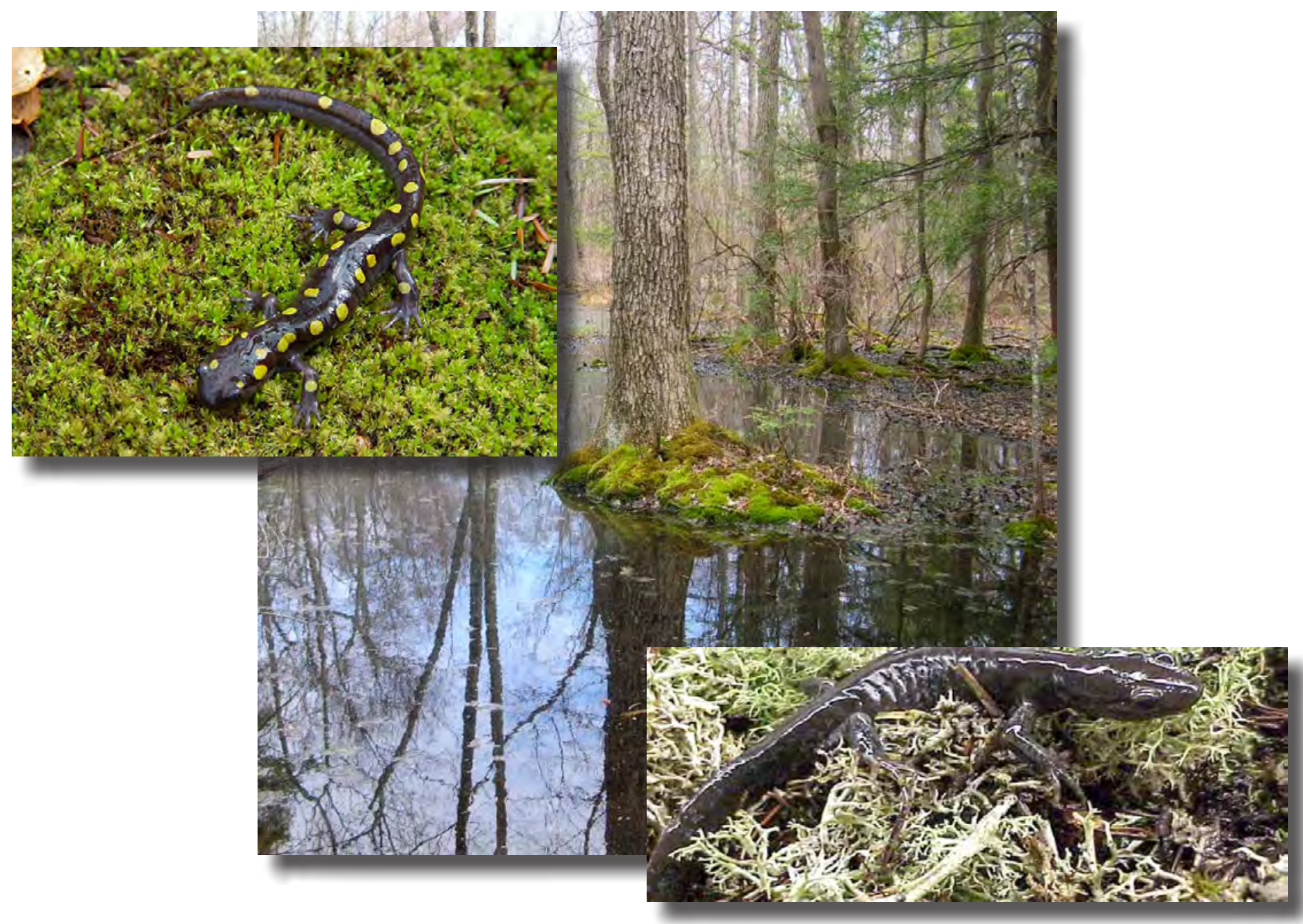

Scientific Investigations Report 2020-5081 


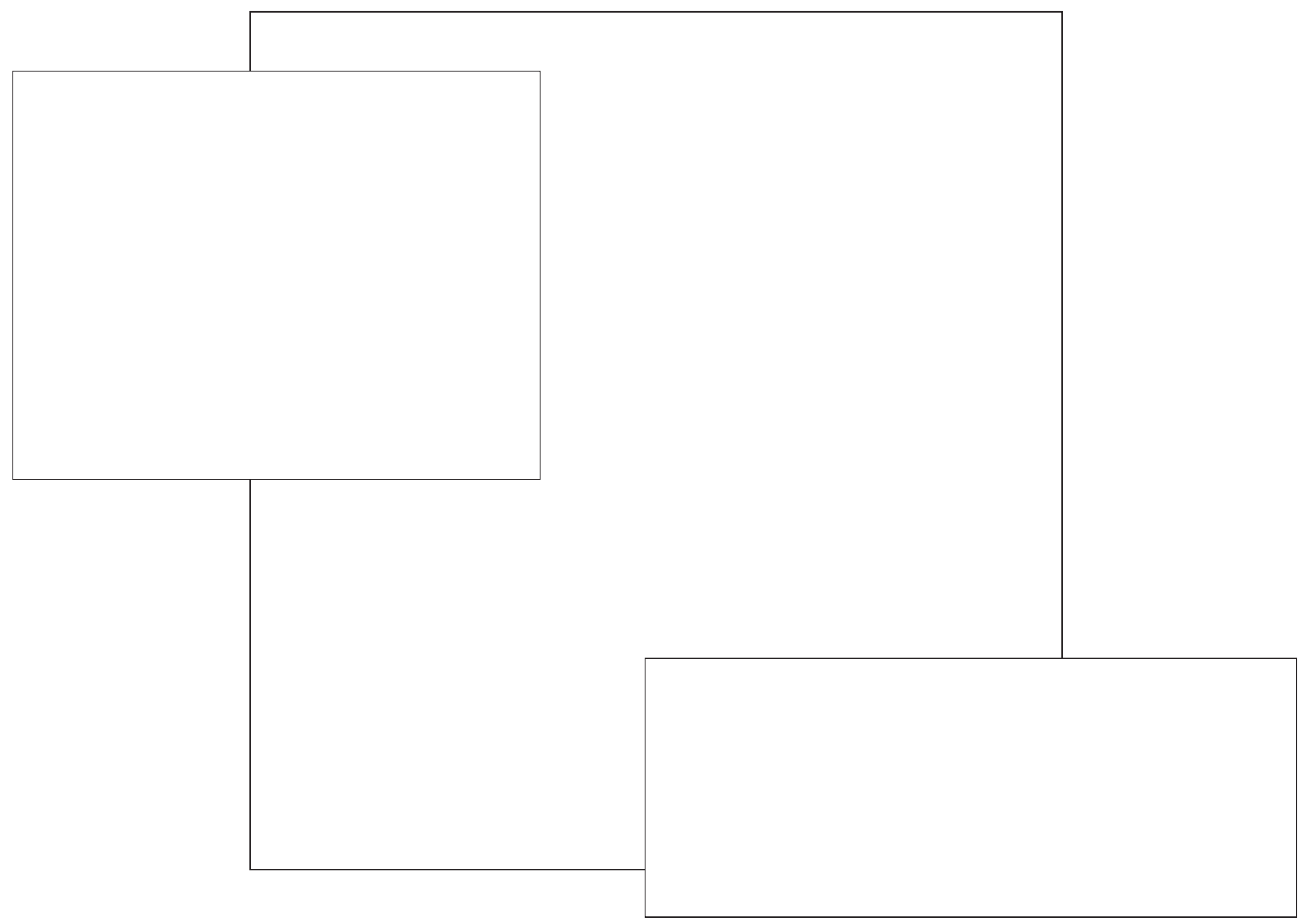

Cover. Top left photo is spotted salamander (Ambystoma maculatum), bottom right is Jefferson salamander (Ambystoma jeffersonianum), and the large center photo is a seasonally flooded wetland in Delaware Water Gap National Recreation Area and an example of mole salamander breeding habitat. Photographs by Craig Snyder, U.S. Geological Survey 


\section{Assessment of Ambystomatid Salamander Populations and Their Breeding Habitats in the Delaware Water Gap National Recreation Area}

By Craig D. Snyder, John A. Young, James T. Julian, Tim L. King, and Shanon E. Julian

Prepared in cooperation with the National Park Service

Scientific Investigations Report 2020-5081 


\title{
U.S. Department of the Interior \\ DAVID BERNHARDT, Secretary
}

\author{
U.S. Geological Survey \\ James F. Reilly II, Director
}

U.S. Geological Survey, Reston, Virginia: 2020

For more information on the USGS - the Federal source for science about the Earth, its natural and living resources, natural hazards, and the environment-visit https://www.usgs.gov or call 1-888-ASK-USGS.

For an overview of USGS information products, including maps, imagery, and publications, visit https://store.usgs.gov/.

Any use of trade, firm, or product names is for descriptive purposes only and does not imply endorsement by the U.S. Government.

Although this information product, for the most part, is in the public domain, it also may contain copyrighted materials as noted in the text. Permission to reproduce copyrighted items must be secured from the copyright owner.

Suggested citation:

Snyder, C.D., Young, J.A., Julian, J.T., King, T.L., and Julian, S.E., 2020, Assessment of Ambystomatid salamander populations and their breeding habitats in the Delaware Water Gap National Recreation Area: U.S. Geological Survey Scientific Investigations Report 2020-5081, 41 p., https://doi.org/10.3133/sir20205081.

Associated data for this publication:

Snyder, C.D., and Young, J.A., 2019, Ambystomatid salamander population and breeding pond habitat data for the Delaware Water Gap National Recreation Area (2001-2003): U.S. Geological Survey data release, https://doi.org/10.5066/P9XCVHY3.

ISSN 2328-0328 (online) 


\section{Acknowledgments}

Richard Evans of the Delaware Water Gap National Recreation Area was instrumental in providing management perspectives, project coordination, and logistical support for the project. Al Ambler, National Park Service, provided location and site information for impoundments and other spatial data collected by the park and was extremely helpful in providing background information on how data were historically collected and stored by park staff. David Weller, John Swift, Glenn Nelson, Mary Mandt, and many others from USGS Leetown Science Center, assisted in data collection. Thorough reviews were provided by Randy Bennett, Nathaniel Hitt, and Christine Densmore. Their comments greatly improved the clarity and continuity of the report. 



\section{Contents}

Acknowledgments ……...................................................................................................................

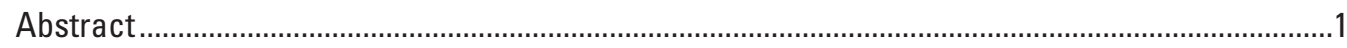

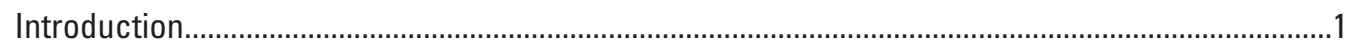

Study Area

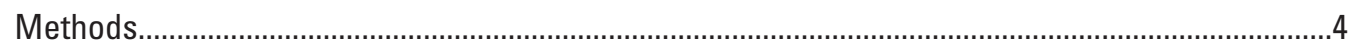

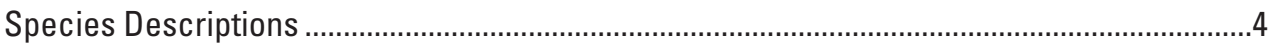

Landscape Analyses and Site Selection ...........................................................................

Weather Pattern Assessment.................................................................................................

Salamander and Pond Habitat Sampling ................................................................................

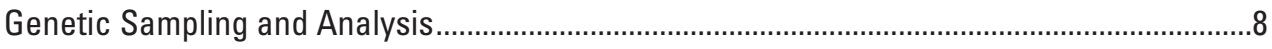

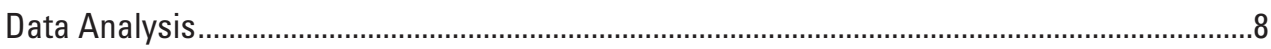

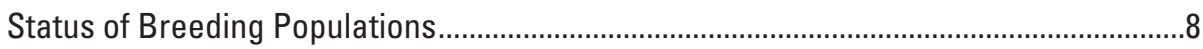

Assessment of Critical Breeding Habitats.......................................................................

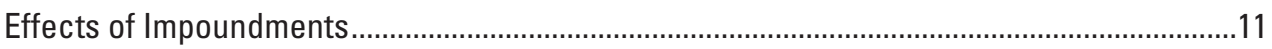

Findings

Weather Patterns............................................................................................................

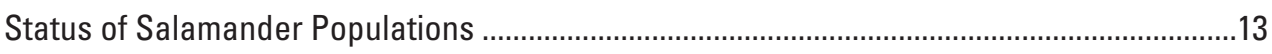

Ambystoma maculatum ....................................................................................... 13

Ambystoma jeffersonianum ......................................................................................

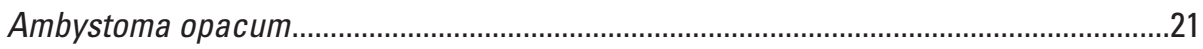

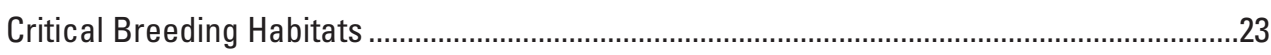

Ambystoma maculatum ......................................................................................2

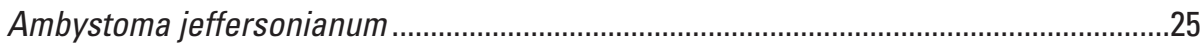

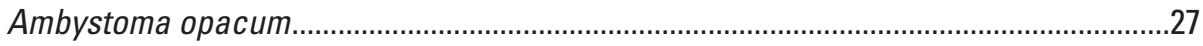

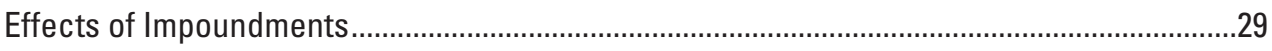

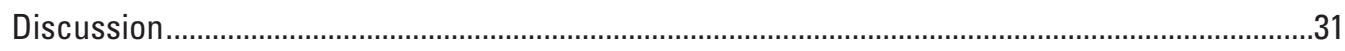

Status and Critical Breeding Habitats of Salamander Populations ..........................................31

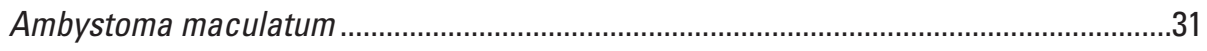

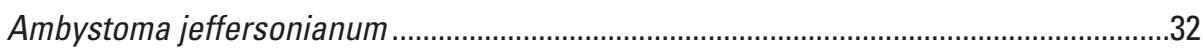

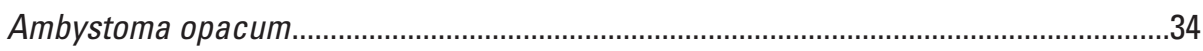

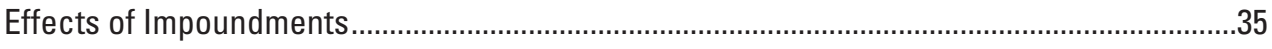

Management Implications …………................................................................................

Summary

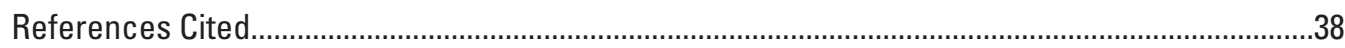

\section{Figures}

1. Map showing location of Delaware Water Gap National Recreation Area ......................3

2. Graphs showing monthly total precipitation and air temperature patterns for northeastern New Jersey ...........................................................................................12

3. Map showing location of Ambystoma maculatum breeding sites in Delaware Water Gap National Recreation Area . 
4. Graphs showing proportion of randomly selected natural wetlands containing Ambystoma maculatum egg masses and the proportion of $A$. maculatum breeding sites of different population sizes for each of 3 study years, Delaware Water Gap National Recreation Area, 2000-03.

5. Graphs showing Ambystoma maculatum egg mass abundance as a function of wetland location.

6. Map showing location of Ambystoma jeffersonianum breeding sites in the Delaware Water Gap National Recreation Area.

7. Graphs showing proportion of randomly selected natural wetlands containing Ambystoma jeffersonianum egg masses and the proportion of Ambystoma jeffersonianum breeding sites of different populaton sizes in Delaware Water Gap National Recreation Area

8. Graphs showing Ambystoma jeffersonianum egg mass abundance as a function of wetland location, Delaware Water Gap National Recreation Area .21

9. Map showing location of Ambystoma opacum breeding sites in the Delaware Water Gap National Recreation Area.

10. Graph showing proportion of randomly selected natural wetlands containing Ambystoma opacum in the Delaware Water Gap National Recreation Area...

11. Schematic diagram showing pruned classification tree showing Ambystom maculatum egg mass occurrence as a function of landscape, near-pond habitat, and in-pond habitat.

12. Schematic diagram showing pruned regression tree showing Ambystoma maculatum egg mass abundance as a function of landscape, near-pond habitat, and in-pond habitat

13. Schematic diagram showing pruned classification tree showing Ambystoma jeffersonianum egg mass occurrence as a function of landscape, near-pond habitat, and in-pond habitat.

14. Schematic diagram showing pruned regression tree showing Ambystoma jeffersonianmum egg mass abundance as a function of landscape, near-pond habitat, and in-pond habitat.

15. Schematic diagram showing pruned classification tree showing Ambystoma opacum egg mass occurrence as a function of landscape, near-pond habitat, and in-pond habitat

16. Graph showing Ambystoma opacum occurrence at sites sampled in only 1 year and sites sampled in 2 or 3 years. Numbers above each set of bars represent the total number of sites.

17. Graph showing percent of wetlands and impoundments used for breeding by the three ambystomatid salamander species and the percent of all natural wetlands and impoundments available on the landscape, Delaware Water Gap National Recreation Area

18. Graph showing percent of sampled sites and all sites with and without fish used for breeding by the three ambystomatid salamander species, Delaware Water Gap National Recreation Area

19. Graph showing percent of sites with Ambystoma maculatum egg masses as a function of site type, impoundment or natural wetland, and fish presence/ absence, Delaware Water Gap National Recreation Area, 2001-02

20. Graph showing results of logistic regression analysis to determine the effects of site type and fish on Ambystoma maculatum breeding site selection in the Delaware Water Gap National Recreation Area, 2001 and 2002 
21. Graph showing proportion of ponds with hemlock and without hemlock within 200-m buffers in relation to hydroperiod score, Delaware Water Gap National Recreation Area

\section{Tables}

1. Distribution, by number and percentage, of available ponds, randomly sampled ponds, and non-randomly sampled ponds among 12 habitat types, by type, vegetation, and topography in the Delaware Water Gap National Recreation Area .......6

2. Suite of habitat variables measured for each pond or wetland and used as predictor variables in Classification and Regression Tree analyses.

3. Comparison of pond sizes (area) and A. maculatum egg mass abundances between sampling years $(2001,2002$, and 2003) for the 30 ponds that were sampled all three years

4. Ambystoma jeffersonianum breeding population size, percent viable egg masses, and percent of embryos identified as laterale-jeffersonianum biotypes at individual breeding ponds or wetlands assessed in Delaware Water Gap National Recreation Area during spring sampling in 2001-03.

5. Between-year change in the percentage of ponds or wetlands with increasing or decreasing Ambystoma jeffersonianum egg mass abundance and percentage of viable egg masses in Delaware Water Gap National Recreation Area

6. Sampling frequency and Ambystoma opacum occurrence probabilities among classification tree terminal nodes .

7. Measures of isolation for impoundments used as breeding sites by Ambystoma maculatum in Delaware Water Gap National Recreation Area

\section{Conversion Factors}

International System of Units to U.S. customary units

\begin{tabular}{lll}
\hline \multicolumn{1}{c}{ Multiply } & \multicolumn{1}{c}{ By } & \multicolumn{1}{c}{ To obtain } \\
\hline centimeter $(\mathrm{cm})$ & Length & \\
millimeter $(\mathrm{mm})$ & 0.3937 & inch (in.) \\
meter $(\mathrm{m})$ & 0.03937 & inch (in.) \\
kilometer $(\mathrm{km})$ & 3.281 & foot (ft) \\
\hline & 0.6214 & mile (mi) \\
\hline square meter $\left(\mathrm{m}^{2}\right)$ & Area & \\
hectare $($ ha) & 0.0002471 & acre \\
square hectometer $\left(\mathrm{hm}^{2}\right)$ & 2.471 & acre \\
square kilometer $\left(\mathrm{km}^{2}\right)$ & 2.471 & acre \\
square centimeter $\left(\mathrm{cm}^{2}\right)$ & 247.1 & acre \\
square meter $\left(\mathrm{m}^{2}\right)$ & 0.001076 & square foot $\left(\mathrm{ft}^{2}\right)$ \\
square centimeter $\left(\mathrm{cm}^{2}\right)$ & 10.76 & square foot $\left(\mathrm{ft}^{2}\right)$ \\
square hectometer $\left(\mathrm{hm}^{2}\right)$ & 0.1550 & square inch $\left(\mathrm{ft}^{2}\right)$ \\
\end{tabular}




\begin{tabular}{lll}
\hline \multicolumn{1}{c}{ Multiply } & \multicolumn{1}{c}{ By } & \multicolumn{1}{c}{ To obtain } \\
\hline hectare (ha) & 0.003861 & square mile $\left(\mathrm{mi}^{2}\right)$ \\
square kilometer $\left(\mathrm{km}^{2}\right)$ & 0.3861 & square mile $\left(\mathrm{mi}^{2}\right)$ \\
\hline
\end{tabular}

Temperature in degrees Celsius $\left({ }^{\circ} \mathrm{C}\right)$ may be converted to degrees Fahrenheit $\left({ }^{\circ} \mathrm{F}\right)$ as follows:

$$
{ }^{\circ} \mathrm{F}=\left(1.8 \times{ }^{\circ} \mathrm{C}\right)+32 .
$$

Temperature in degrees Fahrenheit $\left({ }^{\circ} \mathrm{F}\right)$ may be converted to degrees Celsius $\left({ }^{\circ} \mathrm{C}\right)$ as follows:

$$
{ }^{\circ} \mathrm{C}=\left({ }^{\circ} \mathrm{F}-32\right) / 1.8 \text {. }
$$

\section{Datum}

Horizontal coordinate information is referenced to the North American Datum of 1983 (NAD 83), Zone $18 \mathrm{~N}$.

\section{Supplemental Information}

Specific conductivity is given in microsiemens per centimeter at 25 degrees Celsius $(\mu \mathrm{S} / \mathrm{cm}$ at $\left.25^{\circ} \mathrm{C}\right)$.

Acidity is expressed as $\mathrm{pH}$ or the negative log of hydrogen ion concentrations.

\section{Abbreviations}

DEWA Delaware Water Gap National Recreation Area

NPS National Park Service

USGS U.S. Geological Survey 


\title{
Assessment of Ambystomatid Salamander Populations and Their Breeding Habitats in the Delaware Water Gap National Recreation Area
}

\author{
By Craig D. Snyder1, John A. Young1', James T. Julian2, Tim L. King1', and Shanon E. Julian³
}

\section{Abstract}

This report presents abundance and occurrence data for three species of ambystomad salamanders (Ambystoma maculatum, A. jeffersonianum, and A. opacum) collected over a 3-year period $(2000,2001$, and 2002) at 200 potentional breeding sies within the Delaware Water Gap National Recreation Area (DEWA). In addition, numerous measures of inpond, near-pond, and landscape attributes were measured and used to inform statistical models to determine specieshabitat relationships in the DEWA.

The results of a 3-year study of ambystomatid salamander breeding habits and habitats in the (DEWA) that was conducted by the U.S. Geological Survey, in cooperation with the National Park Service, are described in the report. The objectives of the study were to document the population status and critical breeding habitats of the three species of ambystomatid salamanders known to be present in the DEWA-Ambystoma maculatum (spotted salamander), A. opacum (marbled salamander), and A. jeffersonianum (Jefferson salamander). DEWA managers are interested in ecological information on these species for several reasons. First, at the time the study began, there was little known regarding the status of pondbreeding amphibians and their habitats in the DEWA. Second, because they require undegraded habitats in both terrestrial and aquatic habitats to successfully complete their life cycles, the status of ambystomatid salamanders is widely viewed as indicative of overall ecosystem health. Third, because ambystomatid salamanders and other pond-breeding amphibians have been observed in numerous artificial impoundments with the DEWA, park managers would like to assess whether dismantling or discontinuing maintenance of artificial impoundments could affect pond-breeding amphibians and possibly other species that use pond or wetland habitats in the Park.

In 2001, 2002, and 2003, the size and location of 200 wetlands, ponds, and artificial impoundments, and related landscape positions (Ridge versus Valley; Pennsylvania side

1U.S. Geological Survey.

2Pennsylvania Department of Conservation and Natural Resources.

${ }^{3}$ U.S. Fish and Wildlife Service, Northeast Fishery Center. versus New Jersey side of the Delaware river) were mapped, and site habitat data relating to salamander occurrence and abundance patterns were collected. The data collected during this study provide important new baseline information on ambystomatid salamanders and wetland habitats in the DEWA that will enhance long-term inventory and monitoring efforts. In addition, breeding habitat assessments indicate that ambystomatid salamanders may be sensitive to a wide variety of stresses important in the DEWA and in the region. In particular, recent trends in development (for example, roads) in and near the DEWA, regional increases in the acidity of precipitation, and predicted long-term warming trends for the region could be detrimental to pond-breeding salamander populations because of their effects on breeding site quality and quantity, and on the integrity of migration corridors. In contrast, the results of the study indicate management plans to eliminate small impoundments are not likely to adversely affect salamanders in DEWA, at least in the short-term. However, it is possible that these small impoundments may offer stable habitats that provide a rescure effect during long-term droughts.

\section{Introduction}

Amphibians are integral components of North American wetland and forest ecosystems. In terms of diversity, amphibians represent approximately 12.5 percent of the total terrestrial vertebrate species in North America, and the Appalachian Highlands in eastern North America support a particularly high number of endemic amphibian species (Bury and others, 1995). In addition, amphibians frequently represent the largest fraction of vertebrate biomass. For example, salamander biomass in a northern hardwood ecosystem in New Hampshire was more than twice that of the bird community and nearly equal to that of small mammals (Burton and Likens, 1975), whereas in southern Appalachian forests, salamander biomass may exceed that of all other vertebrates combined (Hairston, 1987).

Concern over amphibians has heightened in recent years owing to increasing evidence of global and regional population declines, range reductions, and extinctions (Wyman, 1990). In the United States, about one-third of amphibian species are suspected of having declines (Bury and others, 1995). These 
declines are not limited to highly degraded areas. Significant losses of amphibians have been documented in relatively pristine areas, such as national parks, that generally lack obvious habitat loss or alteration (Blaustein and Wake, 1990). Suspected causes of these regional declines include climate change (Pounds, 2001; Carey and Alexander, 2003), acid deposition (Freda, 1986; Dunson and others, 1992), depletion of the ozone layer (Blaustein and others, 1995), and disease and parasites (Muths and others, 2003).

The Delaware Water Gap National Recreation Area (DEWA; also referred to as "Park") is a 277-square kilometer $\left(\mathrm{km}^{2}\right)$ landscape that straddles a 65-kilometer $(\mathrm{km})$ reach of the Delaware River in northeastern Pennsylvania and western New Jersey (fig. 1). The National Park Service (NPS) manages the land for recreation, including fishing, hunting, hiking, and boating. Within the nearly 28,400 hectares of the DEWA are hundreds of wetlands, vernal ponds, swamps, marshes, beaver ponds, and impoundments that provide potential amphibian habitat. Seven amphibian species have been documented in DEWA that are classified as "species of special concern" by the States of Pennsylvania or New Jersey. Three of these species are pond-breeding ambystomatid salamanders: Ambystoma jeffersonianum (Jefferson salamander), Ambystoma maculatum (spotted salamander), and Ambystoma opacum (marbled salamander). Ambystomatid salamanders (commonly referred to as "mole salamanders") live most of the year underground in forested areas but emerge in early spring and migrate to woodland ponds and wetlands to breed and deposit eggs (Hulse and others, 2001). Adults return to their terrestrial habitats soon after breeding, and the eggs hatch as aquatic larvae that remain in their natal breeding pond for various amounts of time depending on hydroperiod, thermal regime, predation, competition, and other related factors (Dodd and Cade, 1998).

In addition to the regional stresses referred to above, there is also concern that more local stresses may affect amphibian populations. For instance, rapid human population growth and associated residential development in areas adjacent to DEWA may negatively affect many species of pond-breeding amphibians owing to pollution (for example, road salt runoff, herbicides, pesticides), direct destruction of terrestrial and aquatic habitats, and the disruption of dispersal corridors by roads. The counties surrounding DEWA have been among the fastest growing counties in Pennsylvania and New Jersey for more than a decade (Pennsylvania State Data Center, 2020).

Activities within DEWA may also threaten salamander populations. Currently, DEWA actively manages beaver and is considering dismantling many of the 120 human-made impoundments within the Park. These actions may affect the size, number, and distribution of ponds that may be important breeding habitats for ambystomatid salamander populations. In addition, DEWA supports a network of roads and trails that may influence migratory behavior and success by fragmenting dispersal corridors. Finally, DEWA management leases more than 3,000 acres for agriculture under special permits and has recently initiated special riparian conservation and restoration measures. Information regarding the distribution, abundance, and habitat requirements of these salamander species within DEWA is needed to inform management decisions.

The objectives of the project, which was conducted by the U.S. Geological Survey (USGS) in cooperation with the National Park Service, were to document the population status and critical breeding habitats of ambystomatid salamanders in DEWA. The information will have immediate and long-term implications for the management and preservation of natural resources in DEWA. In the short-term, the data collected can be used to evaluate the importance of small, human-made impoundments in DEWA as habitat for pond-breeding amphibians. Data on population and habitats were collected and analyzed in such a way as to address the question of impoundment use by ambystomatid salamanders. In the longer term, the data can provide DEWA management staff with baseline information on the status of wetland habitats and ambystomatid salamander populations in the Park, which can be used to assist in preservation of Park biodiversity and to predict the consequences of landscape changes resulting from DEWA management actions or increased development outside the Park. In addition, updated wetland maps and baseline information regarding wetlands and wetland communities that resulted from the study could be used in future long-term monitoring programs in DEWA (for example, the National Park Sevice Vital Signs program). Because of their need for both optimal terrestrial and aquatic habitat to complete their life cycles, ambystomatid salamanders and their habitats may be particularly useful indicators of overall ecosystem health.

This report presents egg mass abundance and egg mass and larval occurrence data for three species of ambystomad salamanders (Ambystoma maculatum, A. jeffersonianum, and A. opacum) collected over a 3-year period $(2000,2001$, and 2002 ) at 200 potentional breeding sies within the DEWA. In addition, numerous measures of inpond, near-pond, and landscape attributes were measured and used to inform statistical models to determine species-habitat relationships in the DEWA.

\section{Study Area}

DEWA encompasses $277 \mathrm{~km}^{2}$ of forested hills, ravines, and bottom lands that straddles a $65-\mathrm{km}$ reach of the Delaware River (fig. 1). The topographic setting is varied, with terraced benches and ravines on the western (Pennsylvania) side of the river within the Appalachian Plateau physiographic province and steeply sloping ridge-valley landforms on the eastern (New Jersey) side of the river within the Valley and Ridge physiographic province (Snyder and others, 2002). The varied landscape supports a wealth of wetlands including marshes, swamps, beaver ponds, and vernal ponds, as well as human-made impoundments. Excluding impoundments larger than 1 hectare (ha), DEWA has at least 317 wetlands or water bodies ( 1.45 wetlands per $1 \mathrm{~km}^{2}$ ) that offer potential ambystomatid salamanader breeding habitat. This is a relatively high density of wetlands (Gibbs, 2000), especially considering the relatively steep terrain over much of the landscape. 


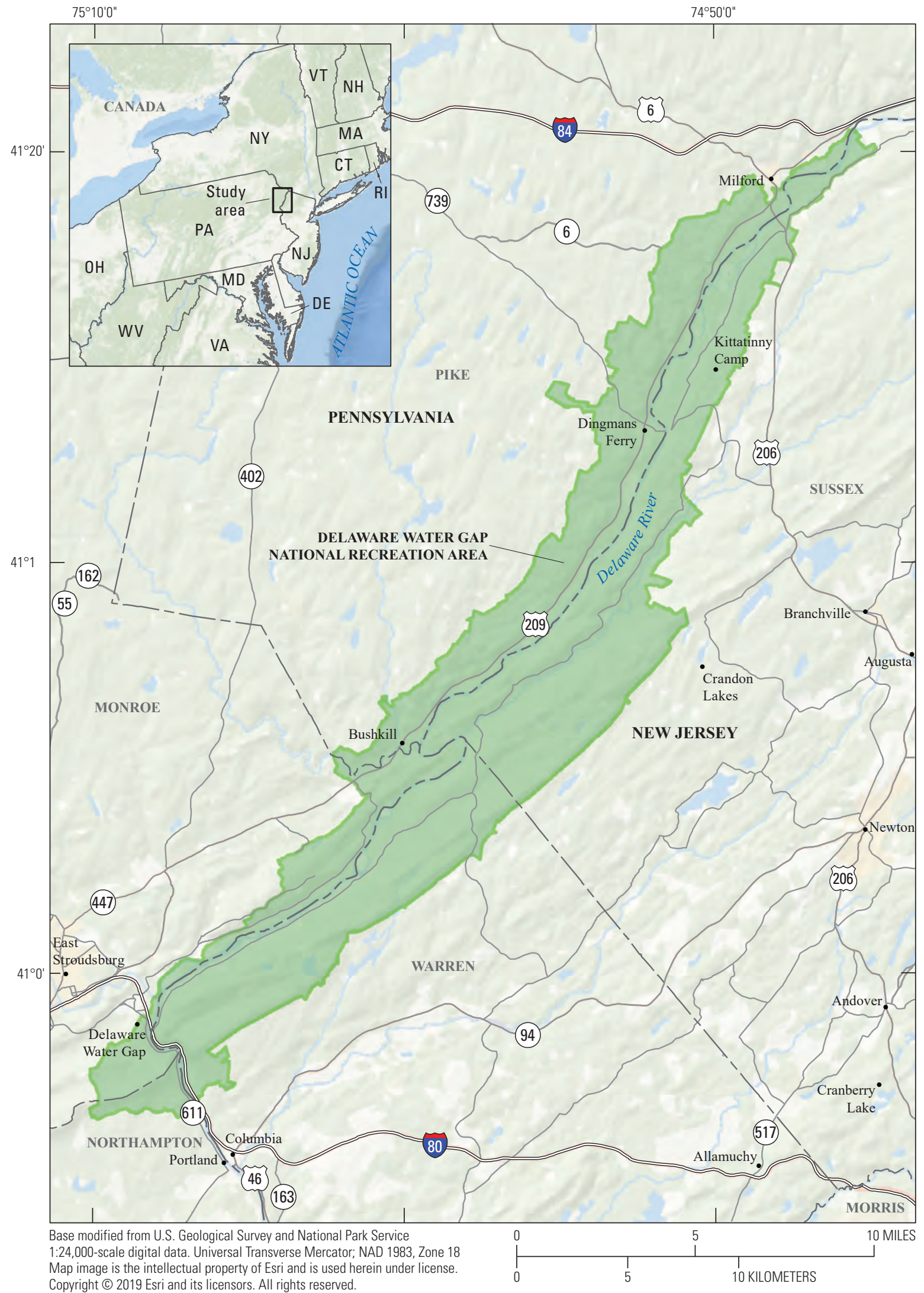

Figure 1. Location of Delaware Water Gap National Recreation Area. 


\section{Methods}

\section{Species Descriptions}

The three species of ambystomatid salamanders present in DEWA are Ambystoma jeffersonianum (Jefferson salamander), A. maculatum (spotted salamander), and A. opacum (marbled salamander). Ambystomatid salamanders typically breed in vernal bodies of water where they function as the community's top aquatic predator (Davic and Welsh, 2004). Ambystoma jeffersonianum and A. maculatum migrate to bodies of water in the early spring and lay egg masses. Larvae hatch within 2-6 weeks (depending on water temperature) and feed on a variety of invertebrate and vertebrate prey (including other amphibian larvae). Larvae will metamorphose in 2-4 months and initiate a terrestrial lifestyle. Ambystoma opacum, however, lay eggs during the late summer or fall in dried vernal ponds or the shores of permanent ponds that have dried considerably. Eggs hatch when ponds refill with water, and aquatic larvae over-winter at the bottom of ponds. Thus, in the spring, $A$. opacum larvae are considerably larger than sympatric $A$. jeffersonianum and A. maculatum larvae and enjoy a competitive and predatory advantage. Previous amphibian surveys of DEWA (Freda, 1985; Stein, New Jersey State Museum, unpub. data, 1978; D. Brotherton and J.L. Behler, Wildlife Conservation Society, unpub. data, 2000) have noted that A. maculatum is the most common ambystomatid salamander at DEWA, breeding in many bodies of water that retain water through the spring months, whereas A. jeffersonianum and A. opacum appear to have a much more limited distribution (historically breeding at only 6 and 10 sites, respectively).

Although all three species of Ambystoma in DEWA are commonly described as breeding primarily in ephemeral bodies of water (Conant and Collins, 1998; Petranka, 1998), each species was observed in permanent bodies of water during this study. Furthermore, other investigators have suggested that artificial bodies of water may prove to be important features in preserving amphibian biodiversity in some areas (Laan and Verboom, 1990; Beebee, 1997; Monello and Wright, 1999), although artificial bodies of water with permanent hydroperiods frequently support predatory fish and macroinvertebrate species (Skelly, 2001). Adults of some amphibian species, however, have been shown to avoid breeding in bodies of water that contain fish (Semlitsch, 1988; Resetarits and Wilbur, 1991; Hopey and Petranka, 1994). The composition of amphibian assemblages is strongly affected by the wetland hydroperiod (Kolozsvary and Swihart, 1999; Snodgrass and others, 2000), and amphibian species that are most successful at colonizing and occupying permanent bodies of water are typically large anurans (notably Rana catesbeiana and Rana clamitans in the northeastern U.S.) or species that are highly noxious to predators (for example Rana palustris and Notophthalmus spp). Large anuran species, in turn, prey on adult, juvenile, and larval stages of smaller amphibian species (Werner and others, 1995), and Notophthalmus spp. are known to prey on egg and larval stages (Conant and Collins, 1998; Petranka, 1998).

In addition to being historically the least common ambystomatid species in DEWA, $A$. jeffersonianum is a species of special concern within the Park because their breeding success can be compromised at breeding sites that are shared with unisexual (all female), triploid, populations of Ambystoma jeffersonianum-complex biotypes. These unisexual Ambystoma biotypes possess three sets of chromosomes instead of two, and the nomenclature used to identify members of this complex reflect their genetic makeup (that is, LJJ is an individual with one set of A. laterale (blue-spotted salamander) and two sets of $A$. jeffersonianum chromosomes). Unisexual Ambystoma biotypes typically reproduce through gynogamy and are sperm parasites of bisexual, diploid Ambystoma spp. (typically A. jeffersonianum and A. laterale populations). Sperm from bisexual Ambystoma are used to initiate mitotic division in non-reduced eggs of unisexual biotypes, and the resulting offspring typically do not contain paternal genetic material. In A. jeffersonianum populations with only diploid (JJ) individuals, male:female ratios are typically greater than 3:1 (Petranka, 1998), but in diploid-unisexual populations male:female ratios can become less than 1:10 (Nyman and others, 1988). When this occurs, egg mortality can be high owing to insufficient insemination of both JJ and LJJ females (Petranka, 1998). Traditionally, unisexual and bisexual individuals were distinguished from each other with techniques that worked best when blood/tissue samples were collected from adults (karyotyping, examination of erythrocyte nuclei, and electrophoresis), although molecular techniques have been developed that allow scientists to use individual eggs and pre-hatchlings for biotype identification (Julian and others, 2003).

\section{Landscape Analyses and Site Selection}

A geographic information system (GIS) was used to compile and relate geo-referenced information on terrain, vegetation, and hydrology to the locations of all known ponds, wetlands, and impoundments in DEWA. The goal was to determine the landscape setting of all the potential breeding habitats in the Park and to use the information to develop a stratified sampling design that was representative of landscape variability. Potential ambystomatid salamander breeding habitat was defined as any wetland that contained water during the breeding season of A. maculatum and A. jeffersonianum (typically March and April), except for artificial impoundments that are larger than 1 ha in surface area. Large impoundments were excluded because they contain large populations of predatory fish and because the sampling effort required to adequately characterize breeding habitats in these large water bodies is time prohibitive. 
Initially, a "potential breeding site" map was developed by combining existing digital maps of DEWA wetlands and impoundments less than 1 ha. Then this potential breeding site layer was overlaid with digital representations of terrain and land cover. Subsequently, GIS was used to characterize each of the 317 potential breeding habitats in terms of pond type, vegetation type, and topographic setting, as described below.

The "pond type" strata were created by assessing wetland and impoundment maps prepared by DEWA personnel (High, 1999). Ponds were grouped into strata by selecting polygons with attributes deemed suitable as potential amphibian breeding sites. The wetland layer was coded with modified wetland codes from Cowardin and others (1979) used by the Fish and Wildlife Service National Wetlands Inventory. Pond polygons were sorted into three types: wetlands, natural ponds, and impoundments. Wetlands are defined as those polygons coded as palustrine-emergent, palustrine-scrub/shrub, or palustrine-forested. Natural ponds are those polygons coded as palustrine-open water-permanently flooded, palustrine-open water-intermittently flooded, and lacustrine-littoral-open water-permanently flooded. Impoundments are those polygons coded as having been diked, impounded, or excavated. In addition, polygons were coded as being impoundments by overlaying wetland polygons with a point layer of impoundments compiled by DEWA personnel (A. Ambler, DEWA, written commun., 2001). Some impounded ponds in this layer were not present in the wetlands layer, so these were added into the selection strata separately. Finally, additional locations were added into the set of wetlands by incorporating vernal pond point locations compiled by the Wildlife Conservation Society in their 2000 survey (D. Brotherton and J.L. Behler, Wildlife Conservation Society, unpub. data, 2000). Pond type strata were further collapsed into "natural" ponds consisting of all wetlands and natural ponds, and "impoundments" consisting of permanent, impounded water bodies. All pond locations and associated attributes described above are included in the data release associated with this study (Snyder and Young, 2019).

Vegetation type strata for ponds were derived from attributes of wetlands polygons and by an overlay of pond polygons on land cover maps. Specifically, ponds were grouped into herbaceous, scrub-shrub, forested, and agricultural types using wetland vegetation type codes of E (emergent), SS (scrub-shrub), FO (forested) and MOD (modified/agricultural) respectively. Additionally, vegetation type was assessed by overlaying pond polygons on maps of agricultural and forested areas derived from maps of land cover and agricultural fields provided by DEWA personnel. The four strata were further collapsed into three strata of forest, scrub-shrub, and open classes.

Ponds were grouped into topographic categories of ridge, valley, and side-slope on the basis of an evaluation of terrain shape from digital elevation models. An algorithm was used that accounted for concavity and convexity of slopes at multiple scales to classify ponds into categories of topographic position. Field evaluation revealed weaknesses in this approach; therefore, topographic types were consolidated into either valley or ridge ponds.

Site selection had random and non-random components. Because of the apparent rarity of $A$. jeffersonianum breeding populations, and because of the stated concern of DEWA resource managers for this species, all known A. jeffersonianum breeding sites (initially $\mathrm{N}=9$ ) were nonrandomly selected for sampling in all 3 years (2001-03). A strictly random design would have yielded few, if any, A. jeffersonianum sites, whereas the non-random selection of A. jeffersonianum sites would ensure that important ecological and genetic information was collected for this high priority species. Also, any new A. jeffersonianum ponds that were discovered could be sampled in the subsequent year(s).

A stratified random scheme was used to select most sites for sampling during each study year (that is, 2001, 2002, and 2003). Specifically, sites were randomly selected from the 12 strata formed from the various combinations of pond types, topographic positions, and surrounding vegetation (table 1). Over the 3-year period, 200 different sites were sampled; 187 of these were chosen at random at least in the first year they were sampled (that is, A. jeffersonianum was found in some randomly selected ponds and consequently were non-randomly sampled in subsequent years). The remaining 13 sites were chosen because of prior knowledge of the existence of $A$. jeffersonianum. Overall, the 12 strata of potential breeding habitats were sampled in approximately the same proportion as they occurred in the Park (table 1), and a total of 35 sites were sampled all three years.

Ponds selected for sampling were mapped in the field using Trimble mapping-grade Global Positioning System (GPS) receivers during a 2-week period each spring coincident with biological sampling. GPS data files were differentially corrected using base station files from the National Oceanic and Atmospheric Administration Continuously Operating Receiver Station website (https://geodesy.noaa.gov/CORS/). Mean positional error of resulting GPS boundaries was 2.4 meters $(\mathrm{m})$ in year $1,1.1 \mathrm{~m}$ in year 2 , and $1.0 \mathrm{~m}$ in year 3 of the study. Overall accuracy of GPS boundaries was $1.4 \mathrm{~m}$ over the life of the study. Improvements in positional accuracy can be attributed to upgraded GPS equipment in the second year of the study. GPS boundaries were exported as GIS polygon files and edited to remove spikes and other gross errors. Pond area and perimeter were calculated for each pond polygon using GIS software.

In addition to site selection, GIS was used to quantify other important landscape variables for use as explanatory variables in habitat selection models (see "Data Analysis" section farther on). Specifically, measures of wetland isolation and road density in areas around each natural wetland selected for sampling were calculated. The wetland isolation measures were calculated as the number of other potential breeding habitats in specified buffer areas around each selected wetland (that is, the fewer the number of other ponds in buffered areas, the more isolated the breeding pond). The total number of 
water bodies (including human-made impoundments) and the number of natural water bodies were determined for each pond. In addition, each isolation measure was calculated at two scales (that is, buffer areas around focal ponds): 500-m and 1,000-m buffers. Thus, a total of four wetland isolation measures were calculated for each natural wetland selected for sampling.

Road density (meters of road per hectare of buffer area) within 250-m, 500-m, and 1,000-m buffer areas around each selected wetland was calculated. At each scale, the density of primary roads and secondary roads was calculated. The distinction between primary and secondary roads was based on traffic statistics compiled by the Pennsylvania Department of Transportation. Primary roads were defined as roads with greater than 1,000 cars per day. These assessments included only paved roads; for roads in which no traffic data were available, the authors used their best judgment as to whether a road was primary or secondary, based on personal driving experiences in the Park.

Table 1. Distribution, by number and percentage, of available ponds, randomly sampled ponds, and non-randomly sampled ponds among 12 habitat types, by type, vegetation, and topography in the Delaware Water Gap National Recreation Area.

[All, all ponds currently mapped and available, as well as ponds randomly and non-randomly selected for sampling. See "Landscape Analyses and Site Selection" section for details. Impound, Impoundments; N, number; \%, percent; <, less than]

\begin{tabular}{|c|c|c|c|c|c|c|c|c|}
\hline \multirow[b]{2}{*}{ Type } & \multirow[b]{2}{*}{ Surrounding vegetation } & \multirow[b]{2}{*}{ Topography } & \multicolumn{3}{|c|}{ Sampled ponds (N) } & \multicolumn{3}{|c|}{ Sampled ponds (\%) } \\
\hline & & & All & $\begin{array}{c}\text { Non- } \\
\text { random }\end{array}$ & Random & All & $\begin{array}{c}\text { Non- } \\
\text { random }\end{array}$ & Random \\
\hline IMPOUND & FOREST & RIDGE & 17 & 1 & 13 & 5 & $<1$ & 7 \\
\hline IMPOUND & FOREST & VALLEY & 2 & 0 & 2 & 1 & 0 & 1 \\
\hline IMPOUND & OPEN & RIDGE & 5 & 0 & 5 & 2 & 0 & 3 \\
\hline IMPOUND & OPEN & VALLEY & 11 & 0 & 7 & 3 & 0 & 4 \\
\hline IMPOUND & SHRUB/SCRUB & RIDGE & 1 & 0 & 1 & 0.3 & 0 & 0.5 \\
\hline IMPOUND & SHRUB/SCRUB & VALLEY & 0 & 0 & 0 & 0 & 0 & 0 \\
\hline NATURAL & FOREST & RIDGE & 175 & 10 & 92 & 55 & 5 & 49 \\
\hline NATURAL & FOREST & VALLEY & 29 & 2 & 18 & 9 & 1 & 10 \\
\hline NATURAL & OPEN & RIDGE & 16 & 0 & 8 & 5 & 0 & 4 \\
\hline NATURAL & OPEN & VALLEY & 34 & 0 & 18 & 11 & 0 & 10 \\
\hline NATURAL & SHRUB/SCRUB & RIDGE & 14 & 0 & 12 & 4 & 0 & 6 \\
\hline \multirow[t]{2}{*}{ NATURAL } & SHRUB/SCRUB & VALLEY & 13 & 0 & 11 & 4 & 0 & 6 \\
\hline & & TOTALS & 317 & 13 & 187 & & & \\
\hline
\end{tabular}




\section{Weather Pattern Assessment}

Breeding activity of many amphibian species, including ambystomatid salamanders, is strongly affected by weather conditions prior to and during breeding periods (Semlitsch 2000). Air temperature and the amount and timing of rainfall are important because they directly affect the availability and hydroperiod of breeding habitat. Consequently, it is important to put breeding activity observed in any single breeding season in the context of normal weather patterns. To determine how weather affects ambystomatid salamanders, precipitation and air temperature during the 3 study years were graphically compared to historical patterns measured at locations in DEWA.

\section{Salamander and Pond Habitat Sampling}

Each year (2000, 2001, and 2002), selected ponds were sampled for the presence and abundance of $A$. jeffersonianum and $A$. maculatum egg masses, and the presence of A. opacum larvae. Each pond was sampled every 2 weeks in late February or early March (depending on weather) and mid-May. No selected pond was sampled on fewer than three occasions during the season. The presence or absence of fish that were visually observed during each site visit was recorded, though no effort was made to distinguish species known to prey on salamanders.

Egg masses were counted using visual encounter surveys (VES) and one of two sampling schemes. For ponds or wetlands that were either so large or the number of egg masses so great that they could not be completely censused by two investigators within 1.5 hours (that is, 3 person-hours), a transect-based sampling scheme was established that assessed 20 percent of the entire pond or wetland. Transects were established perpendicular to the long axis of the pond, and all egg masses within a specified distance on either side of the transect line were counted. The distance between transects and the width of the search path along the transect line varied depending on the size of the pond. A minimum of five transects was used on each pond to ensure that count data would come from a variety of locations within the pond. Thus, for very large ponds (greater than $100 \mathrm{~m}$ in length along the long axis), transects were laid $20 \mathrm{~m}$ apart, and the width of the search path along the transect line was $4 \mathrm{~m}$. For very small ponds (less than approximately $30 \mathrm{~m}$ along the long axis), transects were laid $5 \mathrm{~m}$ apart, and the search path was $1 \mathrm{~m}$ in width. For intermediate sized ponds (approximately 30-100 $\mathrm{m}$ along the long axis) transects were set at $10 \mathrm{~m}$ apart with a 2-m search path. The location of the first transect in each pond was randomly selected between 0 (one corner of the pond) and the distance between transects. For all other ponds, a complete census was conducted, counting all egg masses in the entire pond.
Although individual egg masses of A. maculatum were easily discerned from one another, counting $A$. jeffersonianum egg masses proved difficult because of conglomerations of closely spaced egg masses and high amounts of embryonic mortality. In instances where individual $A$. jeffersonianum egg masses could not be discerned, the number of egg masses was estimated using an approximation in which each 6-centimeter (cm) length of eggs (the approximate length of a thumb) was assumed to equal one egg mass. Although this approximation was primarily based on field observations on the size of a "typical" A. jeffersonianum egg mass, Bishop (1941) observed that the mean egg mass length of $A$. jeffersonianum in a New York population was similar $(5 \mathrm{~cm})$. In addition to recording the total number of $A$. jeffersonianum egg masses in a pond during a survey, the fraction of egg masses that were viable also was determined. Individual masses were categorized as unviable if greater than or equal to 90 percent of its embryos were dead (covered in fungus). In each year, investigators estimated the proportion of viable masses for each breeding site with the following calculation:

$$
P=\left(N_{t}-N_{w}\right) / N_{t}
$$

where

$$
\begin{aligned}
& P \quad \text { is the proportion of viable egg masses, } \\
& N_{t} \quad \text { is the highest total egg mass count observed } \\
& \text { from a single survey, and } \\
& N_{u} \quad \text { is the highest number of unviable egg masses } \\
& \text { observed from a single survey. }
\end{aligned}
$$

The survey date on which each site that yielded the highest total mass count also was the date on which the site typically yielded the highest unviable mass count ( 86 percent of the time). At sites where this did not occur, the maximum number of total masses occurred on the survey date prior to the date of the observed maximum number of unviable masses. Justification for using "unviable mass counts" from later dates was based on personal observations that unviable egg masses in DEWA persisted for approximately 2 weeks longer than viable masses laid at roughly the same time.

Two methods were used to assess the presence or absence of $A$. opacum larvae. First, a visual search was made for $A$. opacum larvae throughout the pond or along pond transects at the same time as the egg mass surveys. Second, a dipnet survey was conducted at all sites during the same 2-week period when sites were mapped. In 2001 and 2002, VES and dipnet surveys were conducted at all ponds. In 2003, dipnet surveys were conducted only at sites where at least two investigators had not already observed A. opacum larvae using VES. The dipnet survey effort (number of sweeps) was proportional to size of the wetland or impoundment, and two different sampling techniques were used to assure that shallow and deeper waters were sampled adequately. For sites that contained deeper waters towards the interior of the pond (most censused ponds), two dipnet samples were collected every $10 \mathrm{~m}$ around the perimeter of the pond; one sample was collected $1 \mathrm{~m}$ from the shore, and another sample was 
collected $5 \mathrm{~m}$ from the shore towards the pond middle. At wetlands and transected ponds, dipnet samples were collected every $10 \mathrm{~m}$ along each transect because these sites typically contained irregular depth profiles. For both techniques, a 1-m path was swept along the pond bottom at the sampling location. The VES protocols were similar to guidelines set forth by the USGS Amphibian Research and Monitoring Initiative (Corn and others, 2005).

Habitat assessments in the field included information on wetland or impoundment size and hydroperiod, water chemistry, and in-pond and riparian vegetation. Each selected site was mapped using a 12-channel, Trimble GPS mapping unit in the early spring when water levels were highest during the first year the site was selected. The seasonal hydroperiod for all 200 sites sampled was estimated by visiting each site during a single 2-week period in late May and early June 2003 (a fairly typical water year), then each pond was assigned a hydroperiod score based on the difference between the wetted area on that day and the wetted area of the pond when it was at its maximum. Hydroperiod scores were as follows: 0 , dry; 1 , less than 10 percent of seasonal maximum; 2, 11-50 percent of maximum; 3, 51-90 percent of maximum; and 4, greater than or equal to 90 percent of the maximum.

Water chemistry was measured at the same time as mapping was conducted and included conductance (in microsiemens per centimeter) and $\mathrm{pH}$. Specific conductance was measured with a YSI model 33 temperature/salinity/ conductivity meter, and the data were later converted to specific conductivity (in microsiements per centimeter at 25 degrees Celsius) for comparison. The $\mathrm{pH}$ of each site was measured with Orion model $230 \mathrm{~A} \mathrm{pH}$ meters equipped with Orion model 9107BN $\mathrm{pH}$ probes.

In-pond (that is, submerged or emergent) and riparian vegetation was assessed at each site during a 2-week period in mid-May. For in-pond vegetation, the abundance of seven vegetation classes (moss, submerged vegetation, emergent vegetation, shrubs, standing timber, downed logs, and sticks) was ranked on the basis of a visual estimation of the proportion of pond area (that is, fraction of 1-square-meter [ $\left.\mathrm{m}^{2}\right]$ cells) in which each vegetation category occurred. Rankings were as follows: 0,0 percent (absent); 1 , greater than $0-10$ percent (rare); 2, greater than 10-50 percent (common); and 3, greater than 50 percent (abundant). For riparian vegetation, the abundance of six vegetation classes (moss, herbaceous plants, shrubs, coniferous trees, deciduous trees, and total trees) that occurred within a 10-m buffer strip surrounding each pond was ranked. Riparian vegetation was ranked the same way as in-pond vegetation. All count and occurrence data for salamanders, as well as pond habitat data are included in the data release associated with this study (Snyder and Young, 2019).

\section{Genetic Sampling and Analysis}

Genetic analyses were conducted on DNA extracted from A. jeffersonianum embryos collected at all sites in which they were found. Fewer than five embryos were collected from each egg mass sampled from a maximum of 30 egg masses per site. Embryos were excised from masses with dissecting scissors without dislodging the remaining mass from vegetation to which it was attached. Excised embryos were stored in 90 milliliters of pond water until they could be preserved in 95-percent ethanol for genetic analysis. This protocol was chosen because it has been shown to have a negligible effect on the hatching success of the embryos remaining in the egg mass (Julian, 2000). Microsatellite DNA markers were used to detect LJJ biotypes and to evaluate the proportion of diploid and triploid biotypes at each $A$. jeffersonianum breeding site. DNA was extracted from whole embryos and genotyped samples using 16 polymorphic loci, according to protocols described in Julian and others (2003). The biotype was determined for each embryo collected because six of the loci used in the analysis cross-amplified in A. laterale producing triploid banding patterns indicative of LJJ biotypes.

\section{Data Analysis}

\section{Status of Breeding Populations}

Three pieces of information were used to draw inferences on the status of the three ambystomatid salamander species. First, where possible, ambystomatid salamander egg and larvae occurrence data collected during the surveys were compared with data collected during previous surveys. There were four previous biological surveys in DEWA that involved ambystomatid salamanders. Prior to this study, the most extensive survey was coordinated by John Behler of the Wildlife Conservation Society (WCS) in spring 2000 when 148 vernal pools, wetlands, and impoundments were sampled for amphibians (D. Brotherton and J.L. Behler, Wildlife Conservation Society, unpub. data, 2000). The WCS survey evaluated the occurrence of all three species at each site, although each site was visited only once by investigators. Prior to the WCS survey, 35 temporary wetlands in DEWA were sampled in spring 1985 by Joseph Freda, a graduate student at Pennsylvania State University. The temporary wetland survey evaluated the occurrence of $A$. maculatum and A. jeffersonianum but did not attempt to determine the presence of A. opacum (Freda, 1985). Similarly, in 1977 and 1978, Stephen Nyman, a graduate student at Rutgers University sampled two wetlands in DEWA for A. maculatum and A. jeffersonianum. However, this survey involved repeated sampling over multiple site visits, which allowed for acquisition of abundance estimates in addition to presence-absence data (Nyman, 1979). Finally, Joseph Stein conducted surveys at four wetlands in DEWA between 1976 and 1977 and collected occurrence information for all three species (Stein, New Jersey State Museum, unpub. data, 1978). 
Second, temporal trends were assessed at sites sampled during all 3 years of the study $(\mathrm{N}=28)$ to evaluate turnover. Turnover is defined as change in occupancy status at a site between years, and turnover rate is the proportion of sites that show turnover. Breeding habitats that exhibit turnover for a given species indicates that habitat conditions may vary temporally with respect to their suitability for breeding.

Finally, the spatial pattern of breeding pond use was examined to determine whether salamander breeding populations were distributed at random throughout the DEWA landscape. Non-random distribution indicate other issues besides habitat may be important in explaining breeding site selection. For A. maculatum and A. jeffersonianum, egg mass abundance was correlated with geographic latitude and longitude. Because only presence-absence data were obtained for A. opacum, spatial patterns were not assessed in this way.

\section{Assessment of Critical Breeding Habitats}

Characteristics of ambystomatid breeding habitats were assessed by relating information on landscape setting and pond habitat to salamander occurrence and egg mass abundance patterns. For these assessments, analyses were limited to natural ponds and wetlands that were never observed to contain fish. Effects of fish and impoundments were analyzed separately (see "Effects of Impoundments" section farther on). Data from all three annual surveys were pooled, and a breeding site for a species was defined as a wetland that contained egg masses or larvae of the species on at least one occasion during the period of the study. The investigators recognized that pooling data from different years might have biased their inferences because of species turnover, coupled with survey conditions that result in species detection probabilities less than 1 . However, there was almost no species turnover observed at any of the sites for A. maculatum and A. jeffersonianum, so there should be little bias. In contrast, substantial species turnover was observed in surveys for A. opacum larvae. Investigators tried to account for the potential bias with modified approaches to analyses and with a cautious approach to conclusions for $A$. opacum.

Most habitat variables used in the analyses were measured directly either from digital maps using GIS (for example, most landscape variables, including measures of pond isolation, road density, terrain, and forest vegetation) or in the field $(\mathrm{pH}$, specific conductance, and wetland hydroperiod). However, other habitat statistics were computed from field measurements. Specifically, pond area was derived from the mapped boundaries of each site using Trimble Pathfinder Pro software. In addition, because there was significant correlation between many in-pond and riparian vegetation classes, a non-hierarchical clustering procedure was used to summarize in-pond and riparian vegetation field measurements into a smaller set of uncorrelated vegetation types. To perform these analyses, the "FASTCLUS" procedure in SAS/STAT software, Version 8.2 of the SAS System for Windows was used. This procedure assigns observations (sites) to a fixed number of clusters (determined by the investigator) using a k-means model in which all independent variables are first converted to z-scores (that is, mean of 0 and a standard deviation of 1).

Using cluster analyses, natural ponds and wetlands were classified as either mud/bare bottom ponds, leaf bottom ponds, swamps, or marshes, according to field-based rankings of seven vegetation classes (see "Salamander and Pond Habitat Sampling" above). Most natural sites were categorized as leaf bottom ponds ( $\mathrm{N}=69)$, which were characterized by low amounts of emergent vegetation, submerged vegetation, and shrubs, and higher than average amounts of sticks and leaves. Swamps were the second most common natural pond type $(\mathrm{N}=44)$, and they were characterized by higher than average amounts of in-pond shrubs, saplings, and timber. Mud/bare bottom ponds $(\mathrm{N}=19)$ were characterized by less than average amounts of timber, sticks, and leaves; highly variable amounts of emerged and submerged vegetation were present. Marshes $(\mathrm{N}=18)$ contained consistently high amounts of emerged and submerged vegetation, with average amounts of shrubs, saplings, and timber.

The vegetation surrounding ponds was classified as deciduous tree, coniferous tree, or herbaceous/successional vegetation dominated, according to habitat assessments of $10-\mathrm{m}$ riparian zones that ranked the abundance of herbaceous vegetation, shrubs/saplings, trees (both deciduous and coniferous), deciduous trees only, and coniferous trees only. Most sites were classified as having deciduous riparian zones $(\mathrm{N}=91)$ that contained a relatively high abundance of shrubs/saplings and trees, with deciduous trees being more abundant than coniferous trees. Sites classified as coniferous $(\mathrm{N}=32)$ contained a high abundance of trees, with coniferous trees being more abundant than deciduous trees. Sites classified as being herbaceous/successional $(\mathrm{N}=26)$ had an abundance of herbaceous vegetation but very few trees. Overall, all habitat data collected for each study site were summarized into a suite of 17 predictor variables representing landscape setting and in-pond habitat (table 2).

Classification and Regression Tree (CART) analyses (Breiman and others, 1984) were used to explore associations between egg mass occurrence and abundance data collected for each of the three species of ambystomatid salamanders and the entire suite of 17 predictor variables measured for each pond (table 2). As with traditional modeling techniques, the objective of CART is to explain variation in a categorical response variable (Classification tree) or continuous response variable (Regression tree) using one or more predictor variables. However, unlike many traditional modeling approaches CART analysis remains robust even when subjected to complexities typical of ecological data, such as nonlinear response functions and higher order interactions, unbalanced data, and datasets with missing values (De'ath and Fabricius, 2000; Vayssiêres and others, 2000). For all CART analyses, only data from randomly selected natural wetlands were used.

CART works by using rules based on individual predictor variables to repeatedly split the data into relatively homogeneous groups. A relevant example might be that a classification tree splits the group of potential breeding ponds 
used by $A$. maculatum using the predictor variable pond $\mathrm{pH}$. A split might be that all ponds that had a $\mathrm{pH}$ less than 4.5 were not used by $A$. maculatum for breeding, whereas ponds with $\mathrm{pH}$ greater than 4.5 were used 75 percent of the time. Each split, or branch, results in two subsets of the data called nodes (the entire dataset is referred to as the root node). If the node is not subject to further partitioning, that node is called a terminal node, or leaf. For each node, an algorithm is used to determine which of the myriad of possible splits in a predictor variable best explains the variability in the dependent variable, and whether the node should be terminal or subject to further splits. For a more complete discussion of Tree modeling procedures in ecology, see Urban (2002).

S-Plus statistical software was used to conduct CART. S-Plus uses the binary recursive partitioning algorithm, which maximizes homogeneity within individual nodes, to choose the best set of splits to partition the data. Homogeneity is based on deviance (comparable to the sums of squares in least-square regression analysis). For classification trees, the misclassification error rate was used to evaluate the effectiveness of the tree model to explain the data (that is, presence or absence of salamanders). Misclassification error rate is the number of observations that are incorrectly classified by the model post-hoc. To determine statistical significance of the tree model, the misclassification error rate of the observed model was compared to a suite of 100 null model misclassification error rates. Null model error rates were determined by randomly assigning presence-absence data in the observed proportions to the set of pond habitat data, and then generating a tree model for the randomized dataset. The procedure was repeated 100 times to obtain a distribution of null model misclassification error rates. Thus, the $P$-value of the observed model is the number of times out of 100 iterations that the null model error rate was less than or equal to the error rate of the observed model. Essentially, the same techniques were used to evaluate the effectiveness of observed regression trees, except that instead of using misclassification error rate, the deviance of residuals was used. As mentioned previously, deviance is comparable to the sums of squares of least-square regression.

A model simplification technique developed for tree analyses referred to as "pruning" was conducted. This technique attempts to reduce the number of terminal nodes (model complexity) with only minimal reduction in predictive power (De'ath and Fabricius, 2000). In order to prune the trees, the feature in S-Plus software was used that allows the user to plot the number of misclassification errors for classification trees or residual deviance for regression trees as a function of the number of terminal nodes. Typically, misclassification errors and residual deviance declined exponentially with number of terminal nodes, and the goal was to locate the inflection point in the graph where increasing the number of terminal nodes resulted in only minor improvements in misclassification error rates or residual deviance. The number of terminal nodes at that point was determined, and the model was re-run but this time forcing the final model to have the reduced number of terminal nodes.

Table 2. Suite of habitat variables measured for each pond or wetland and used as predictor variables in Classification and Regression Tree analyses.

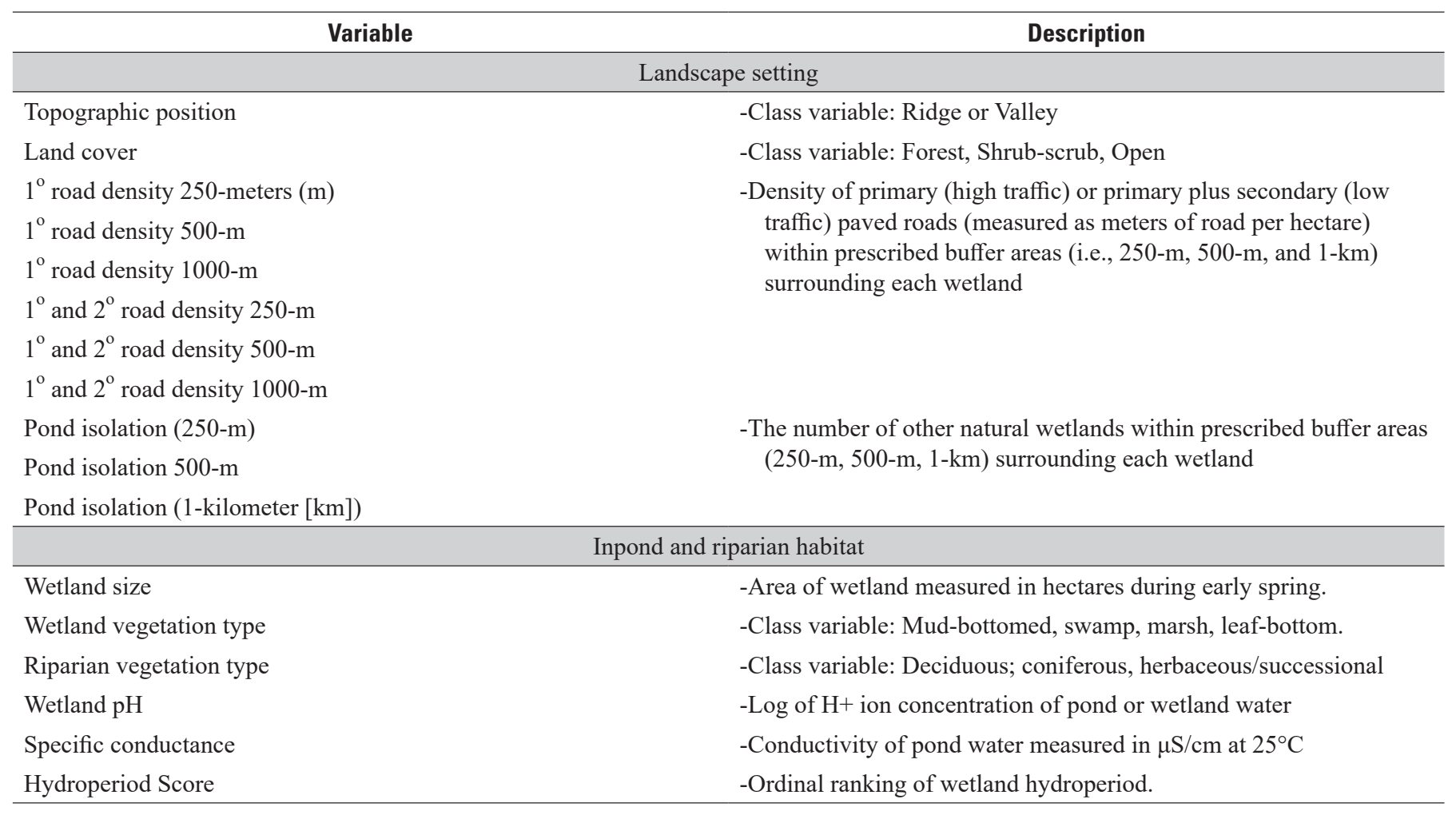




\section{Effects of Impoundments}

Logistic regression was used to model the occurrence and abundance (ranks) of A. maculatum egg masses as a function of pond type (natural pond versus impoundment). The presence or absence of fish, and the interaction between fish presence and pond type, were included as predictor variables in the model to determine whether any impoundment effect was due largely to a correlation between impoundments and fish. For this analysis, data collected from natural sites and impoundments in 2001 and 2002 were used. In the initial analyses, "year" was included as a main effect in the model as were the interactive effects of year with fish and pond type. However, no significant interaction was found between year and the other main effects, so the data from the 2 years were pooled, and the variable "year" was removed from the model. There was no reason to assess statistically the importance of impoundments to the other two species because $A$. jeffersonianum egg masses were never observed in impoundments and A. opacum larvae were observed in only one of the 29 impoundments surveyed.

The logistic regression models used maximum likelihood methods to estimate cumulative logits and regression coefficients for each main effect (McCullagh, 1980). The regression coefficient of a main effect is the natural log of that effect's odds ratio estimate. The odds ratio estimate is the ratio of the odds of a predicted response between levels of a main effect. For example, the odds of amphibian presence in a fishless site is the probability of amphibian presence divided by the probability of amphibian absence. Likewise, the odds of amphibian presence are formed for sites with fish, and the odds ratio for the effect of fish presence is the odds for fishless sites divided by the odds for sites with fish. Odds ratios are easily interpreted because they express a direct association between levels within a main effect (that is, a fishless site has " $X$ " times higher odds of containing egg masses than a site containing fish), where lower bounds of confidence intervals greater than 1.0 or upper bounds less than 1.0 indicate statistical significance (Hosmer and Lemeshow, 1989). Odds ratios and confidence intervals (90 percent) were estimated for each species and years 2001 and 2002.

\section{Findings}

\section{Weather Patterns}

A comparison of observed precipitation and air temperature during the study to historical patterns indicated that, in general, the first and third years of the study were relatively normal in terms of precipitation and temperature, except for the month of October during both years. October of 2000 (year 1) was unusually dry, and October of 2002 (year 3) was unusually wet (fig. 2). In this part of the country, A. opacum migrates to breeding sites in September and October, so unusual conditions in October could affect site selection and breeding success of $A$. opacum. However, in large measure the months leading up to the March-May spring breeding for A. maculatum and A. jeffersonianum, and the nursery period for all three species, was normal for these 2 years. In contrast, the 2001-02 study year was extremely unusual (fig. 2). The 8 -month period (July-February) leading up to the spring breeding season was the driest on record, receiving nearly 38 fewer centimeters of rain than normal (normal $=81.2$ centimeters) for that period. Similarly, the same 8-month period was the second warmest on record, accumulating nearly 15.5 more degree-days (in degrees Celsius) than normal (normal $=78$ degree-days). Data on air temperature and precipitation are from the Office of the New Jersey State Climatologist at Rutgers University. 


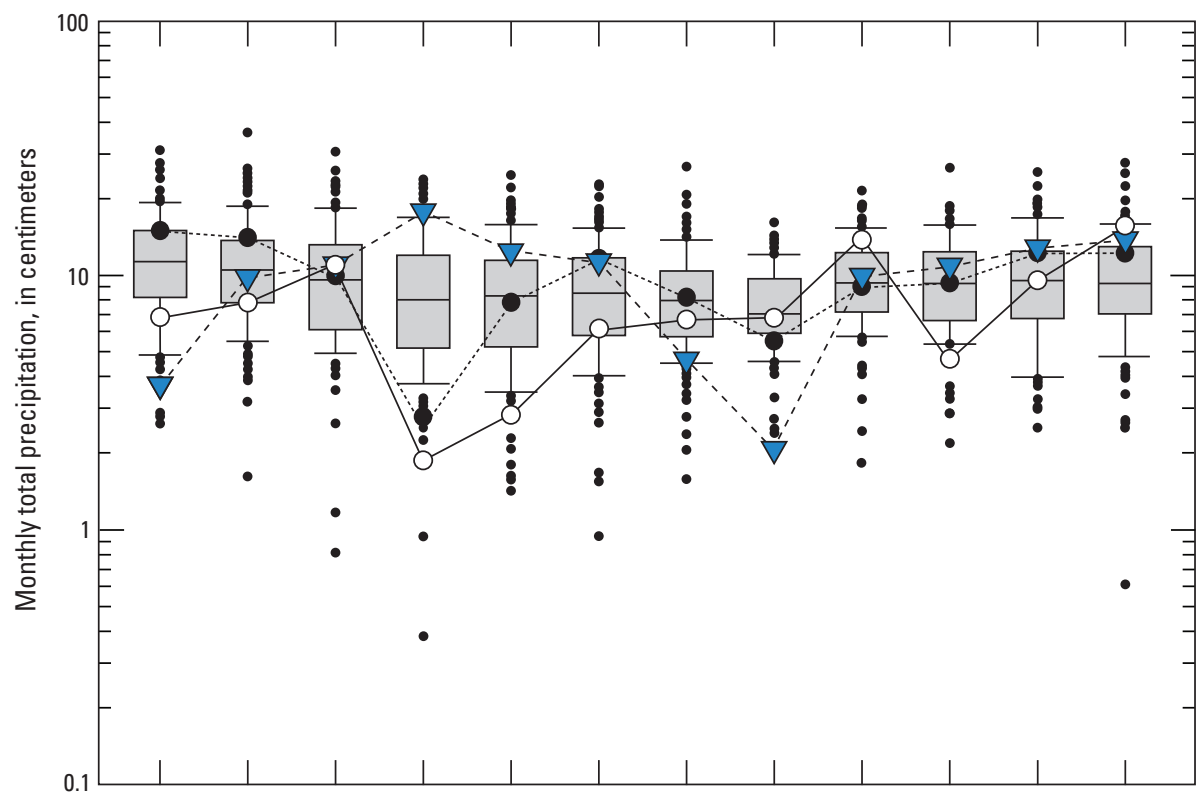

EXPLANATION

- Outlier

7 75th percentile

50th percentile (median)

25th percentile

- Outlier

Historical data

-.. 2000 to 2001

$-\bigcirc-2001$ to 2002

$-\nabla-2002$ to 2003

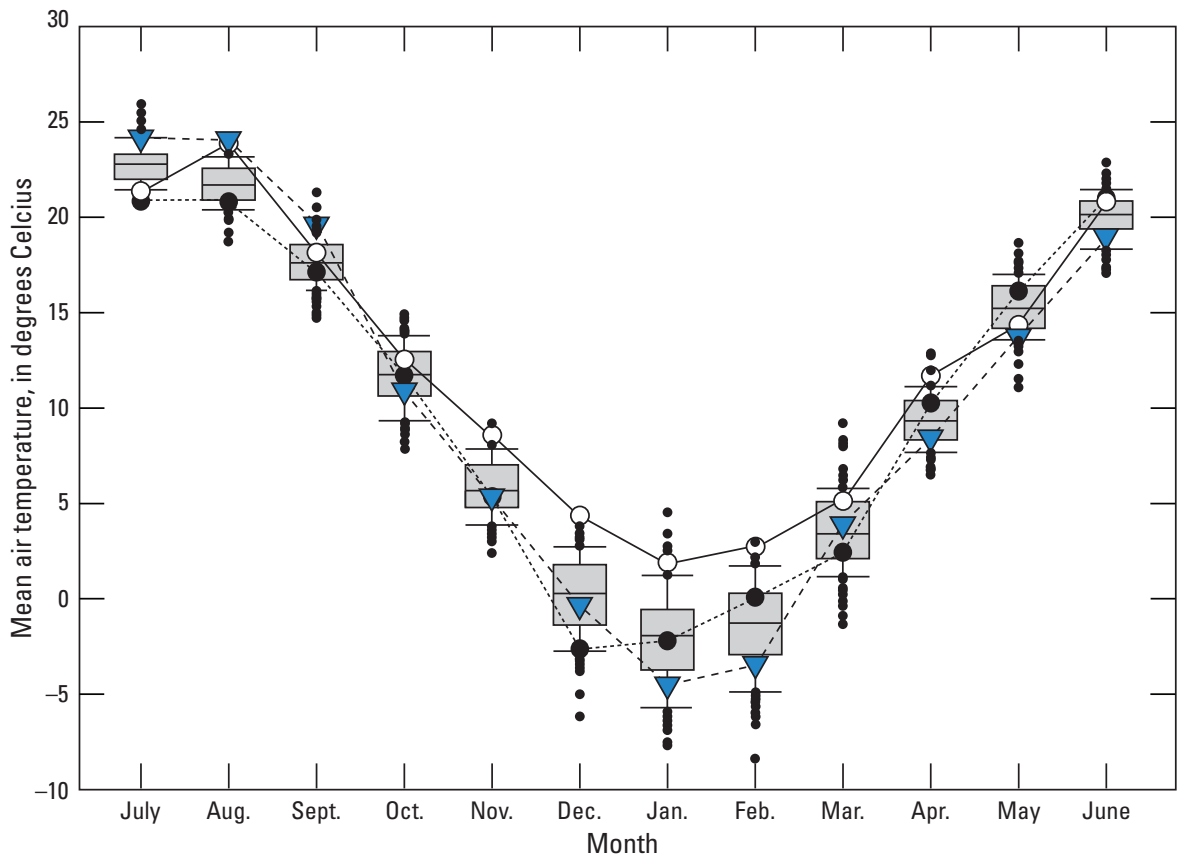

Figure 2. $A$, Monthly total precipitation and $B$, air temperature patterns for northeastern New Jersey. Box plots show the range of monthly values for the 109 -year period from 1895 to 2003 . For each box, the horizontal line shows the grand mean, the extent of the box represents 50 percent of the observations, extent of the whiskers represents 90 percent of the observations, and individual points show remaining data. Lines depict monthly averages during the 3 years of the study. Data used were obtained from the Office of the New Jersey State Climatologist, Rutgers University (https://climate.rutgers.edu/stateclim/). 


\section{Status of Salamander Populations}

\section{Ambystoma maculatum}

Two-thirds of the 200 bodies of water surveyed during the study contained $A$. maculatum egg masses ( $\mathrm{N}=132)$; nearly one-quarter of all surveyed bodies of water contained greater than 100 egg masses in at least 1 year in which they were surveyed $(\mathrm{N}=46)$ (fig. 3 ). When only natural ponds and wetlands were considered and impoundments were excluded, A. maculatum had used 69.6 percent (119/171) of the wetlands in DEWA.

Nearly 57 percent of the breeding ponds identified in the surveys $(\mathrm{N}=75)$ were not previously known to harbor breeding populations of $A$. maculatum. Previous surveys collectively identified $81 \mathrm{~A}$. maculatum breeding sites (hereafter referred to as "historical breeding sites") of a combined total of 149 sites surveyed (54.4 percent occupancy rate for the Park). This is a considerably smaller proportion of sites occupied than the 69.6 percent observed in this study. A total of 59 A. maculatum historical breeding sites were surveyed, and egg masses wwere observed in all but 2 (3.4 percent). Egg masses were present in 17 of 37 sites ( 45.9 percent) in which previous surveys failed to detect $A$. maculatum.

Over the 3 years of the study, the proportion of A. maculatum breeding sites in the Park increased from 0.59 of the wetlands in 2001, to 0.69 percent in 2002, and to nearly 0.76 percent in 2003 (fig. 4A). At the same time, the fraction of sites that supported large populations (greater than 100 masses) decreased from 42.1 percent in 2001 to 32.6 perceent in 2002, to 27.8 percent in 2003 fig. 4B). For sites sampled in all 3 years for both salamanders and pond area $(\mathrm{N}=30)$, changes in egg mass abundance among years were compared to changes in pond sizes to determine whether the wide variation in rainfall (fig. 2) and consequently pond size may have affected salamander breeding patterns over time. Natural sites typically were smallest in 2002 and largest in 2003 (table 3). Of the 30 sites, 25 ( 83.3 percent) were smallest in 2002, and 21 (70 percent) were largest in 2003. Among the 25 sites where $A$. maculatum occurred in at least one year, 22 (88 percent) were smaller in size in 2002 compared to 2001, and 22 (88 percent) were smaller in 2002 compared to 2003, and 18 (72 percent) were smaller in 2001 compared to 2003 (table 3). A strong, positive correlation between change in A. maculatum egg mass counts and change in pond area was observed between the years of 2001 and 2002. In 2002, 75 percent of sites were smaller in size and contained fewer egg masses than in 2001. However, only a weak correlation was observed between the years 2002 and 2003 when one-half of the sites were larger in size but contained fewer egg masses in 2003 compared to 2002. In addition, a negative correlation between egg mass abundance and wetland size was observed between 2001 and 2003, when in 2003, 62 percent of sites were larger in size yet contained fewer egg masses than in 2001. Thus, variation in rainfall amounts and resulting pond volumes did not explain temporal variation in A. maculatum egg mass abundances. In addition, despite fluctuations in overall egg mass counts between years, egg mass counts at breeding sites rarely changed by an order of magnitude ( 9.6 percent of the time). Moreover, turnover (that is, changes in the occupancy status of a pond or wetland) was even less common, occurring at only 5 percent of the sites.

Spatially, A. maculatum breeding ponds were distributed throughout the Park (fig. 3), although A. maculatum used natural wetlands on the New Jersey side (i.e., western) of the river at a slightly higher rate than on the Pennsylvania (i.e., eastern) side (78 percent compared with 66 percent). No spatial relation was found between the extent of pond use (that is, egg mass abundance) and spatial location within the Park. The abundances of $A$. maculatum egg masses within ponds did not correlate with the predominant east-west or north-south directional gradients (fig. 5).

\section{Ambystoma jeffersonianum}

Of the 200 ponds, wetlands, and impoundments surveyed in this study, A. jeffersonianum bred in 20 (10 percent) (fig. 6). When the assessment is limited to only natural ponds and wetlands, A. jeffersonianum used 11.7 percent (20/171) of the available natural wetlands for breeding. However, these are biased estimates of frequency of occurrence in the Park because they include non-randomly selected sites $(\mathrm{N}=9)$ (see "Methods" section). When only randomly selected sites are included, A. jeffersonianum bred in 5.9 percent (11 of 187) of all sites (including impoundments) or 8 percent of the natural ponds and wetlands in the Park (11 of the 138). Of the 20 wetlands found to contain $A$. jeffersonianum, 5 supported large (501-2,000 egg masses) or very large (greater than 2,000 egg masses) populations.

Overall, 14 A. jeffersonianum breeding sites were identified that were not documented by previous amphibian surveys in DEWA. Collectively, these prior amphibian surveys identified a combined total of only 6 historical breeding sites that contained $A$. jeffersonianum egg masses, larvae, or adults of a combined total of 96 sites surveyed. The 6.25-percent frequency of occurrence observed in historical surveys was only slightly less than the 8 percent rate observed among randomly selected natural wetlands in the study. However, A. jeffersonianum egg masses were observed at 9 sites where previous surveys failed to detect them, in addition to all 6 historical breeding sites.

Long-term temporal changes in pond use were compared at two sites that were intensively sampled in 1978 (Nyman, 1979) and during the present study (2001-03). In 1978, Nyman encircled site 2012 with drift fencing and pitfall traps during spring migrations and captured 29 LJJ females, only $3 \mathrm{JJ}$ females, and no JJ males (determined by erythrocyte examination). Subsequently, all egg masses laid that year were unviable, and he concluded that there was a high likelihood the population would go extinct. In contrast, this study indicates that site 2012 consistently harbored very large breeding populations (well over 100 females), even though a 
large fraction of the population was identified as LJJ biotypes (88 percent) and more than one-half of the observed egg masses were not viable (table 4). In addition, the estimate of nearly 45-percent egg mass viability indicates that the number of male JJ that bred at this site over the last 3 years is considerably higher than in 1978.

The other population monitored by Nyman (1979) and this study (site 600) showed no such dramatic change in egg mass abundance between surveys. At site 600 (table 4), Nyman (1979) counted approximately $160 \mathrm{~A}$. jeffersonianum egg masses and estimated that approximately one-half of the larval population in early June consisted of LJJ individuals. Surveys during this study at site 600 recorded egg mass counts of 507, 49, and 155 masses in 2001, 2002, and 2003, respectively, and genetic analyses concluded that approximately 67 percent of the embryos collected were LJJ individuals.

In contrast to $A$. maculatum, the proportion of natural sites used by $A$. jeffersonianum for breeding decreased over the 3 years of the study (fig. 7A). Like A. maculatum, the relative number breeding sites that supported large populations seemed to decline (fig. 7B). However, the total number of randomly selected breeding sites was small (less than 5); therefore, inferences regarding relative population sizes are tenuous.

When egg mass abundances were compared among all A. jeffersonianum breeding ponds (including non-randomly sampled sites, $\mathrm{N}=20$ ), the number of egg masses deposited in a pond was typically lower in 2002 than in 2001 or 2003 (table 5). In 2002, one-half of the breeding sites had a decrease in egg mass from 2001, whereas the remaining sites showed no change in egg mass abundance. The number of sites that decreased in egg mass abundance from 2001 to 2002 was significantly greater than expected by chance (Sign Test, $P=0.031$ ). Similarly, a little more than one-third of the breeding sites showed an increase in egg mass abundance from 2002 to 2003, and the remaining sites showed no change. The number of ponds increasing in egg mass abundance was significantly greater than expected by chance (Sign Rank test, $P=0.031$ ). In contrast, comparing 2001 to 2003 ,
33 percent of sites decreased in egg mass abundance, 8 percent increased, and 49 percent showed no change (table 5). These changes were not statistically different from chance (Sign test, $P=0.188$ ). The 2002 study year was significantly drier than 2001 or 2003 (fig. 2). Thus, temporal variation in egg mass abundances may be explained by variation in rainfall and the drought of 2002.

Contrary to the relation observed between pond size and egg mass abundance rank, egg mass viability within ponds was highest during the 2002 drought year when pond sizes were smallest. The mean proportion of viable $A$. jeffersonianum egg masses was 34.7 percent $(\mathrm{N}=10$, Standard deviation $[\mathrm{SD}] \pm$ 31.7 percent $)$ in $2001,68.0$ percent $(\mathrm{N}=11, \mathrm{SD} \pm 27.4$ percent $)$ in 2002, and 59.2 percent $(\mathrm{N}=20, \mathrm{SD} \pm 34.0$ percent $)$ in 2003 . All sites had an increase in the proportion of viable egg masses between 2001 and 2002 (Sign test, $P=0.0156$ ) (table 5).

Between 2002 and 2003, the proportion of viable masses decreased in 7 ponds and increased in 4 (Sign Test, $P=0.549$ ), and between 2001 and 2003 viability decreased in 4 ponds and increased in 6 (Sign Test, $P=0.754$ ) (table 5).

Significant spatial clustering of $A$. jeffersonianum breeding sites in DEWA was observed. Of the 20 A. jeffersonianum breeding sites, only 3 were in Pennsylvania. Moreover, although $A$. jeffersonianum breeding ponds were distributed throughout the New Jersey portion of the Park, breeding ponds that consistently supported large $A$. jeffersonianum populations were all clustered in the Camp Kittatiny area of the Park. In each year of the study, 3 of the 6 sites in the Camp Kittatiny area produced greater than 2,000 masses per year, and the remaining 3 sites produced 500-2,000 masses in at least 1 year in which they were surveyed. The spatial clustering was evident in east-west and north-south directions. Excluding Pennsylvania wetlands, egg mass abundances increased toward the east, and especially toward the north in the Park (fig. 8). More than 75 percent of the variation in egg mass abundance was explained by latitude (northing). 


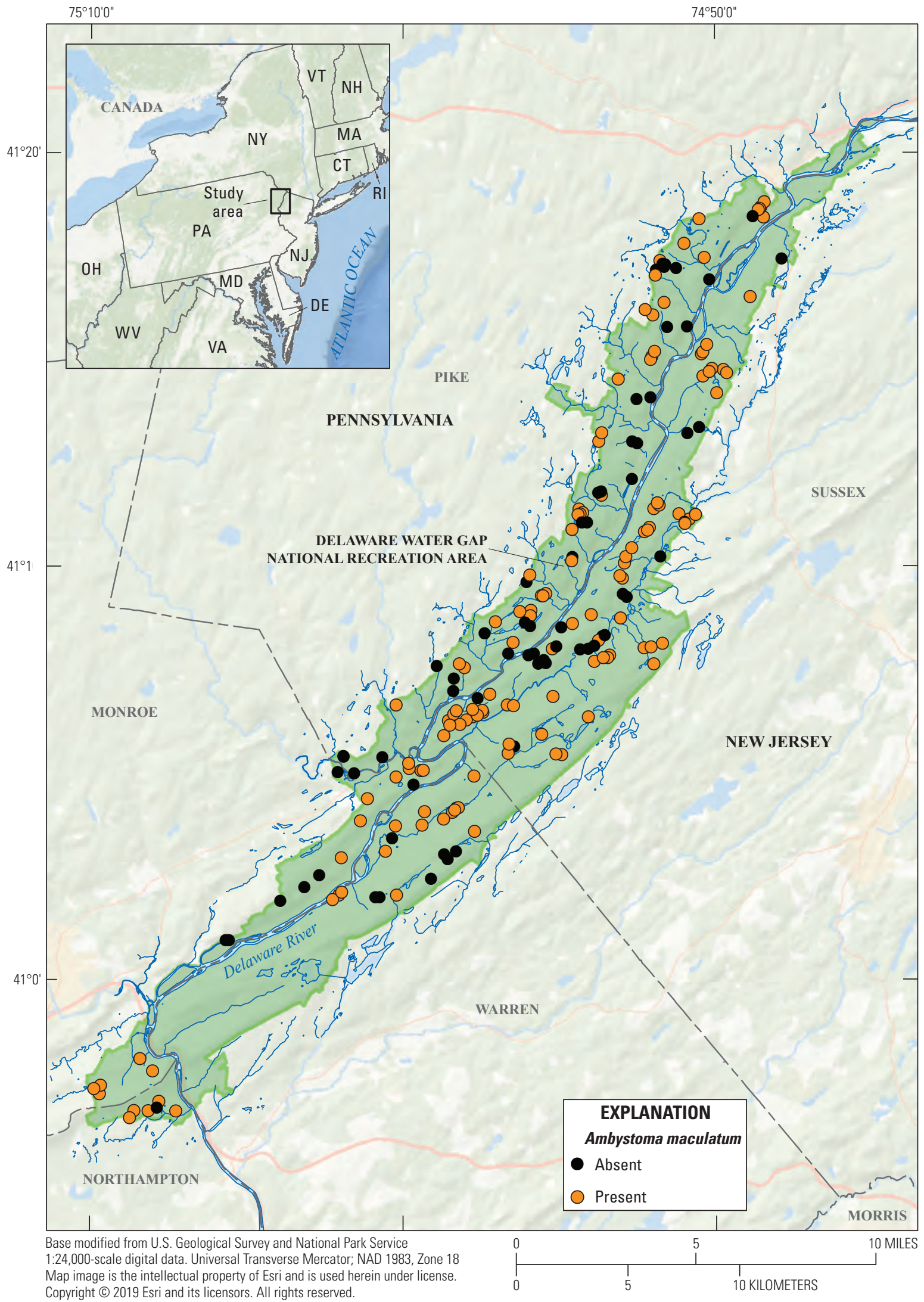

Figure 3. Location of Ambystoma maculatum breeding sites in Delaware Water Gap National Recreation Area. 

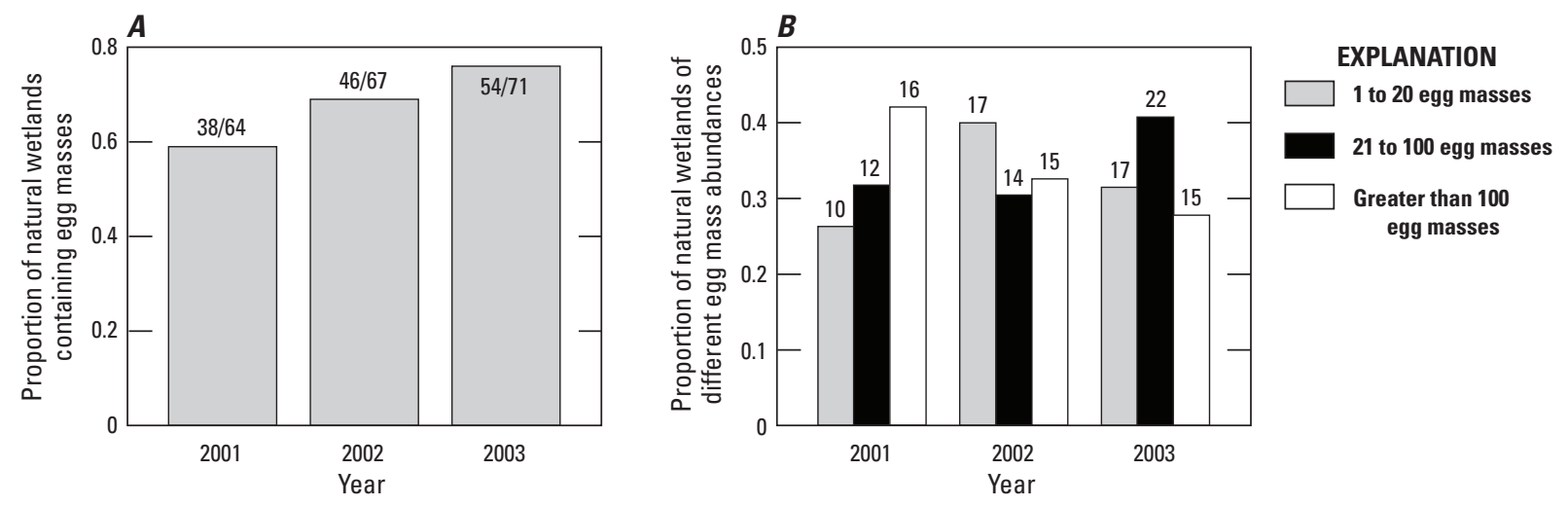

Figure 4. A, Proportion of randomly selected natural wetlands containing Ambystoma maculatum egg masses and $B$, the proportion of $A$. maculatum breeding sites of different population sizes (inferred by egg mass counts) for each of 3 study years, Delaware Water Gap National Recreation Area, 2000-03. Numbers above each bar represent numbers of wetlands.

Table 3. Comparison of pond sizes (area) and A. maculatum egg mass abundances between sampling years (2001, 2002, and 2003) for the 30 ponds that were sampled all three years.

\begin{tabular}{|c|c|c|c|c|c|c|}
\hline \multirow{2}{*}{ Pond number } & \multicolumn{3}{|c|}{ Pond area (hectares) } & \multicolumn{3}{|c|}{ Number of $A$. maculatum egg masses } \\
\hline & 2001 & 2002 & 2003 & 2001 & 2002 & 2003 \\
\hline 80 & 0.338 & 0.055 & 0.628 & 36 & 12 & 11 \\
\hline 245 & 0.076 & 0.034 & 0.134 & 1,865 & 703 & 501 \\
\hline 355 & 0.466 & 0.473 & 0.533 & 50 & 60 & 45 \\
\hline 600 & 0.112 & 0.01 & 0.12 & 87 & 3 & 32 \\
\hline 625 & 0.313 & 0.165 & 0.168 & 3 & 2 & 1 \\
\hline 667 & 0.156 & 0.138 & 0.243 & 35 & 26 & 16 \\
\hline 684 & 0.151 & 0.108 & 0.235 & 0 & 0 & 0 \\
\hline 704 & 0.169 & 0.082 & 0.189 & 87 & 79 & 45 \\
\hline 870 & 0.155 & 0.133 & 0.184 & 755 & 467 & 368 \\
\hline 895 & 0.251 & 0.228 & 0.327 & 0 & 0 & 0 \\
\hline 942 & 0.183 & 0.205 & 0.186 & 1 & 2 & 0 \\
\hline 992 & 0.254 & 0.006 & 0.327 & 738 & 11 & 270 \\
\hline 1096 & 0.388 & 0.267 & 0.405 & 335 & 250 & 75 \\
\hline 2002 & 0.01 & 0 & 0.023 & 67 & 46 & 26 \\
\hline 2012 & 0.045 & 0.04 & 0.034 & 191 & 225 & 265 \\
\hline 2016 & 0.102 & 0.102 & 0.116 & 38 & 32 & 18 \\
\hline 2021 & 0.046 & 0.02 & 0.045 & 0 & 0 & 0 \\
\hline 4008 & 0.068 & 0.028 & 0.114 & 0 & 0 & 0 \\
\hline
\end{tabular}



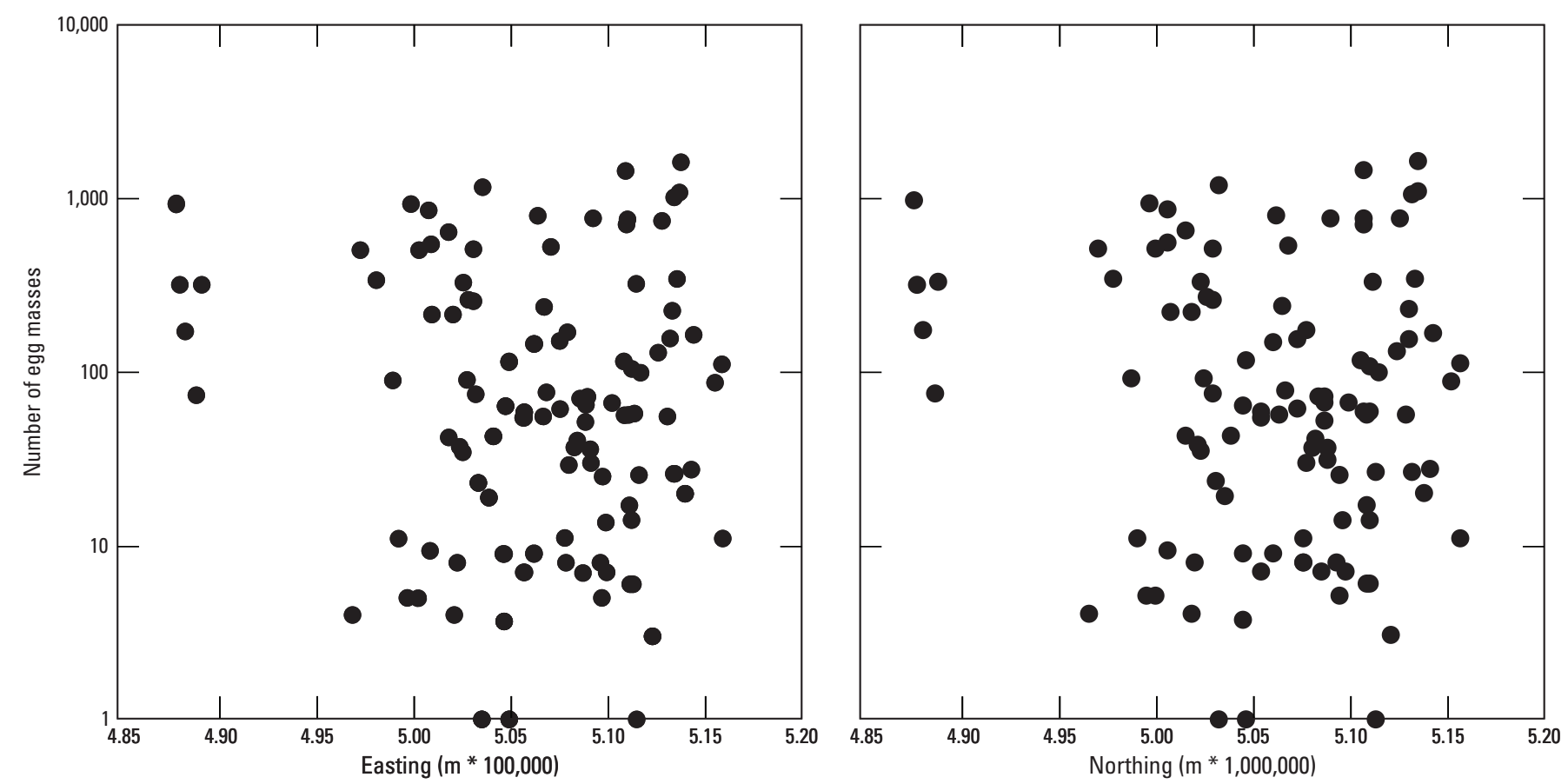

Figure 5. Ambystoma maculatum egg mass abundance as a function of wetland location. Spatial locatons are indicated with Universal Transverse Mercator coordinates and the relation with egg mass abundance is assessed along east-west (easting) and north-south (northing) directions. (m, meter) 


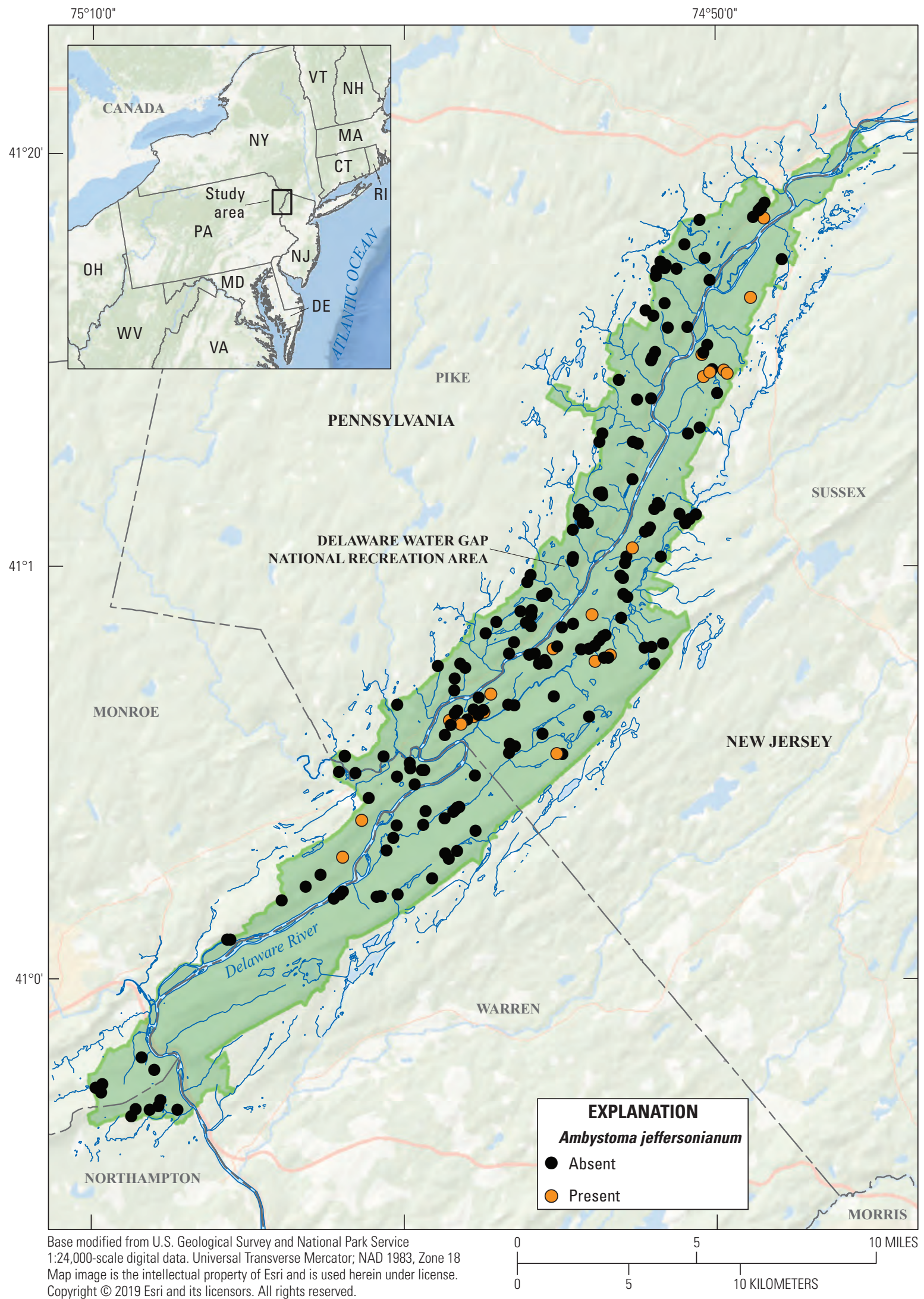

Figure 6. Location of Ambystoma jeffersonianum breeding sites in the Delaware Water Gap National Recreation Area. 
Table 4. Ambystoma jeffersonianum breeding population size, percent viable egg masses, and percent of embryos identified as laterale-jeffersonianum biotypes at individual breeding ponds or wetlands assessed in Delaware Water Gap National Recreation Area during spring sampling in 2001-03.

[Sites highlighted in bold type were intensively sampled in 1979 (Nyman, 1979) as well as during the current study for comparisons. LJJ, laterale-jeffersonianum biotypes; \%, percent; NA, not applicable]

\begin{tabular}{lllccc}
\hline \multicolumn{1}{c}{ Site number } & State & \multicolumn{1}{c}{ Population size $^{1}$} & Mean \% viable & \% LJJ & $\begin{array}{c}\text { Number of genetic } \\
\text { samples }\end{array}$ \\
\hline 688 & NJ & Small & 13 & NA $^{2}$ & 10 \\
704 & NJ & Small & 61 & 100 & 5 \\
2032 & NJ & Small & 100 & 100 & 1 \\
151 & NJ & Large & 80 & 65 & 30 \\
232 & NJ & Moderate & 85 & NA $^{2}$ & 37 \\
245 & NJ & Large & 50 & 75 & 30 \\
$\mathbf{2 0 1 2}$ & NJ & Very Large & $\mathbf{4 5}$ & $\mathbf{8 8}$ & $\mathbf{4 5}$ \\
3012 & NJ & Very Large & 41 & 57 & 30 \\
3013 & NJ & Large & 66 & 79 & 30 \\
801 & NJ & Small & 50 & NA & 0 \\
807 & NJ & Small & 80 & NA & 0 \\
819 & NJ & Small & 45 & 100 & 5 \\
3010 & NJ & Small & 87 & NA & 0 \\
464 & NJ & Small & 5 & NA & 0 \\
$\mathbf{6 0 0}$ & NJ & Moderate & $\mathbf{8 6}$ & $\mathbf{6 7}$ & $\mathbf{3 0}$ \\
758 & NJ & Small & 37 & 19 & 21 \\
3019 & NJ & Small & 87 & 20 & 30 \\
992 & PA & Moderate & 50 & 0 & 30 \\
2035 & PA & Moderate & 77 & 3 & 30 \\
80 & PA & Small & 77 & NA & 0 \\
\hline
\end{tabular}

${ }^{1}$ Based upon mean egg mass abundance across all years sampled (small: 1-100 egg masses; moderate: 101-500 masses; Large: 501-2,000 masses; Very Large: greater than 2,000 masses).

${ }^{2}$ Genetic samples did not resolve.

${ }^{3}$ No samples collected owing to small population size (that is, number of egg masses). 

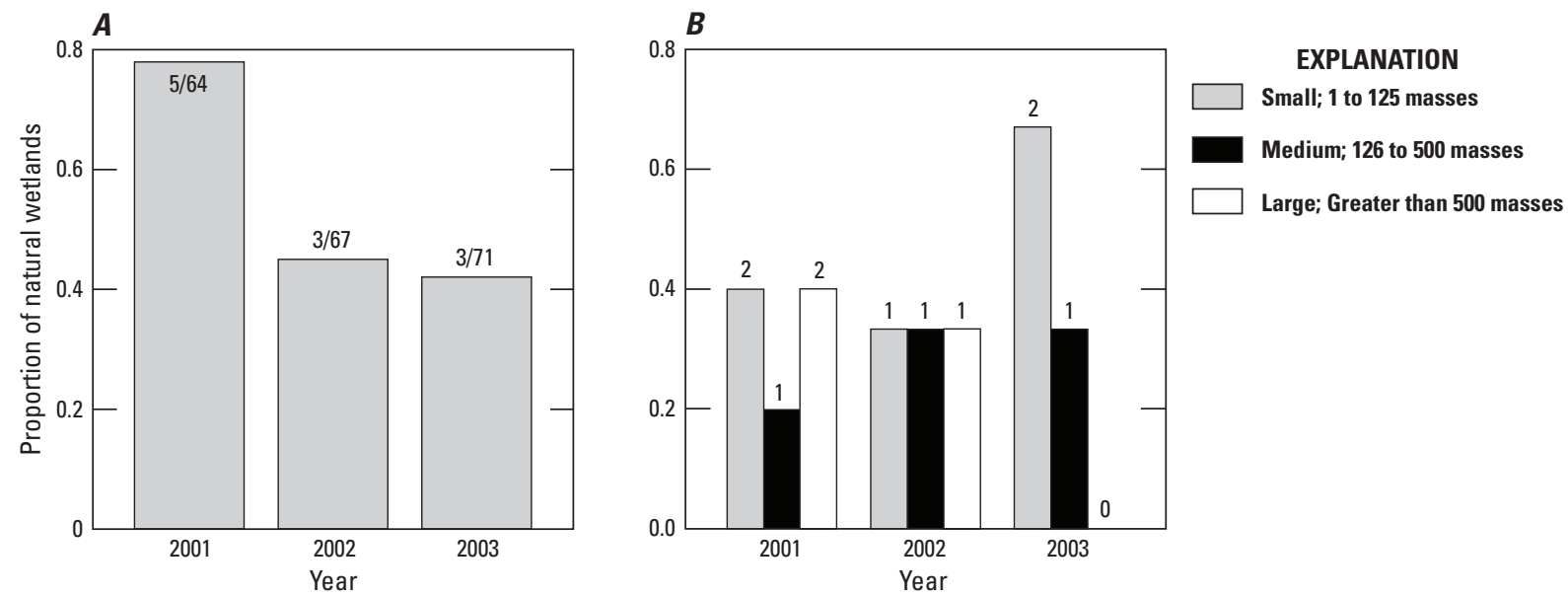

Figure 7. A, Proportion of randomly selected natural wetlands containing Ambystoma jeffersonianum egg masses and $B$, the proportion of Ambystoma jeffersonianum breeding sites of different populaton sizes in Delaware Water Gap National Recreation Area. Numbers above each bar are the actual numbers of wetlands.

Table 5. Between-year change in the percentage of ponds or wetlands with increasing or decreasing Ambystoma jeffersonianum egg mass abundance and percentage of viable egg masses in Delaware Water Gap National Recreation Area.

[For each 2-year comparison, the total number of ponds sampled in both years is shown. N, number; \%, percent]

Percent of ponds or wetlands

\begin{tabular}{lcccccc} 
& \multicolumn{2}{c}{ Change from 2001 to $\mathbf{2 0 0 2}$ (N=10) } & \multicolumn{2}{c}{ Change from 2002 to 2003 (N=14) } & \multicolumn{2}{c}{ Change from 2001 to 2003 (N=12) } \\
\cline { 2 - 7 } & Increase & Decrease & Increase & Decrease & Increase & Decrease \\
\hline Egg mass abundance & $0 \%$ & $50 \%$ & $36 \%$ & $0 \%$ & $8 \%$ & $33 \%$ \\
\hline Viable egg masses & $100 \%$ & $0 \%$ & $36 \%$ & $64 \%$ & $60 \%$ & $40 \%$ \\
\hline
\end{tabular}



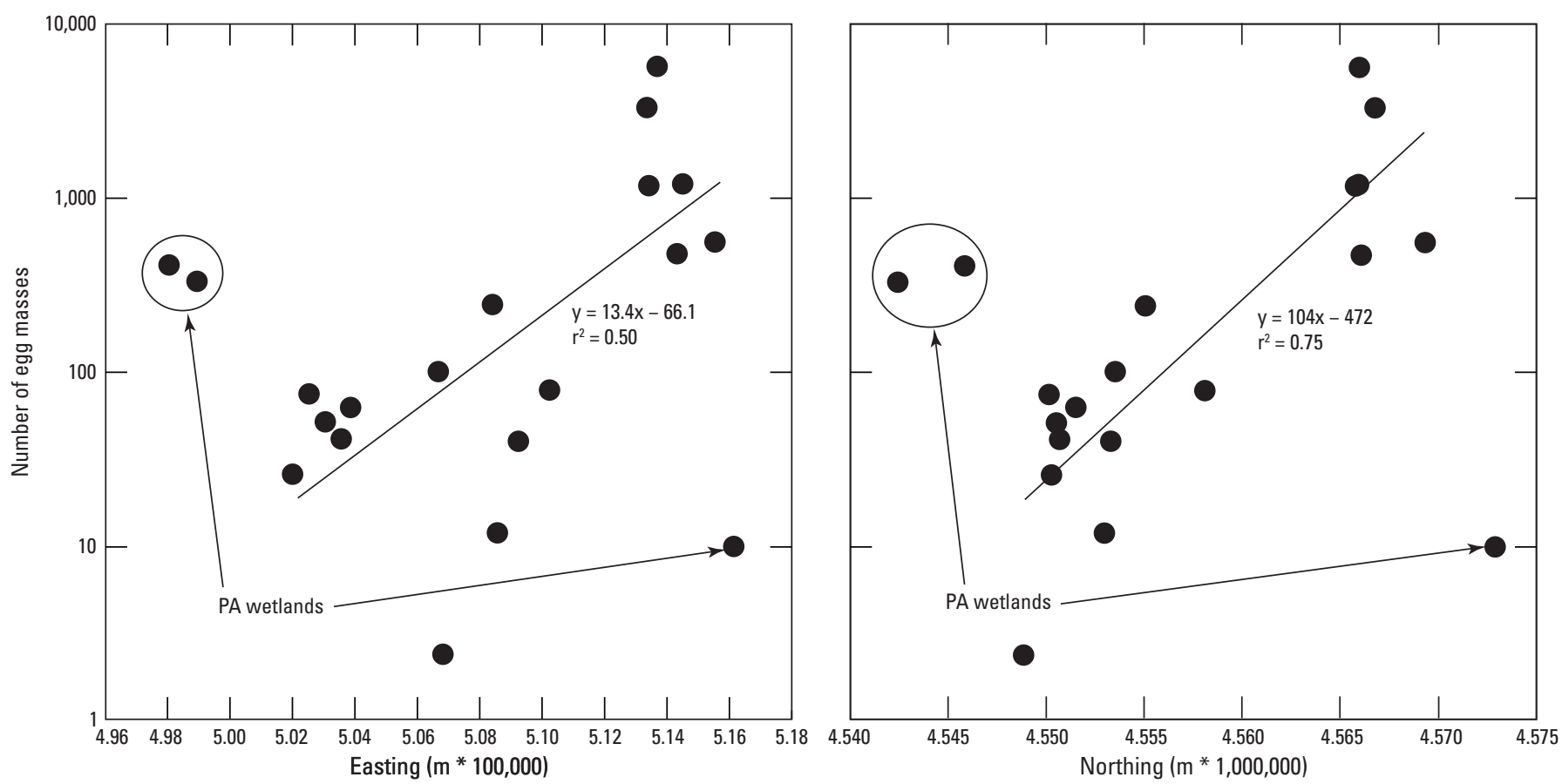

Figure 8. Ambystoma jeffersonianum egg mass abundance as a function of wetland location, Delaware Water Gap National Recreation Area. Spatial location indicated with Universal Transverse Mercator coordinates, and the relation with egg mass abundance is assessed along east-west (easting) and north-south (northing) directions. Pennsylvania wetlands were not included in regressions. [PA, Pennsylvania; m, meter]

\section{Ambystoma opacum}

Of the 200 ponds, wetlands, and impoundments surveyed over the 3 -year period, a total of 40 sites ( 20 percent of total surveyed) were identified that contained $A$. opacum larvae (fig. 9). Of the 171 natural ponds and wetlands, A. opacum was observed in 22.8 percent $(\mathrm{N}=39)$.

Prior to the surveys, A. opacum had been observed at only 11 sites in DEWA. Nine of the 11 historical breeding sites in this study were resurveyed, and A. opacum was found in all 9 ponds or wetlands. In addition, A. opacum larvae were found at 19 sites where prior studies did not detect them and 12 additional sites that had never been surveyed for A. opacum.

Despite large differences in rainfall patterns between years, $A$. opacum occurrence patterns in the Park were remarkably stable over the 3-year study. Specifically, the proportion of natural ponds occupied by A. opacum larvae was about 0.2 for all 3 years surveyed (fig. 10). However, although the probability of occurrence of A. opacum in the Park varied little, high temporal variation was observed in the probability of occurrence among years at individual ponds or wetlands (that is, turnover). Specifically, 10 of $13 \mathrm{~A}$. opacum breeding sites (77 percent) monitored for at least 2 years changed occupancy status at least once between years. Of the 12 breeding sites sampled in 2001 and 2002, 8 (66.7 percent) changed occupancy status ( 7 sites where $A$. opacum was present in 2001 and absent in 2002; 1 site where $A$. opacum was absent in 2001 but present in 2002). Of the 11 sites sampled in 2002 and 2003, 8 (72.7 percent) changed occupancy status ( 2 sites where A. opacum was present in 2002 but was absent in 2003; 6 sites where A. opacum was absent in 2002 but was present in 2003.

Spatially, A. opacum breeding sites were more prevalent on the Pennsylvania side of the river than on the New Jersey side. Nearly one-half (49.4 percent) of all Pennsylvania natural sites surveyed contained A. opacum larvae compared to only 17.4 percent of natural sites surveyed in New Jersey. In contrast, $A$. opacum sites seemed to be widely distributed across latitude (north-south) on both sides of the river (fig. 9). 


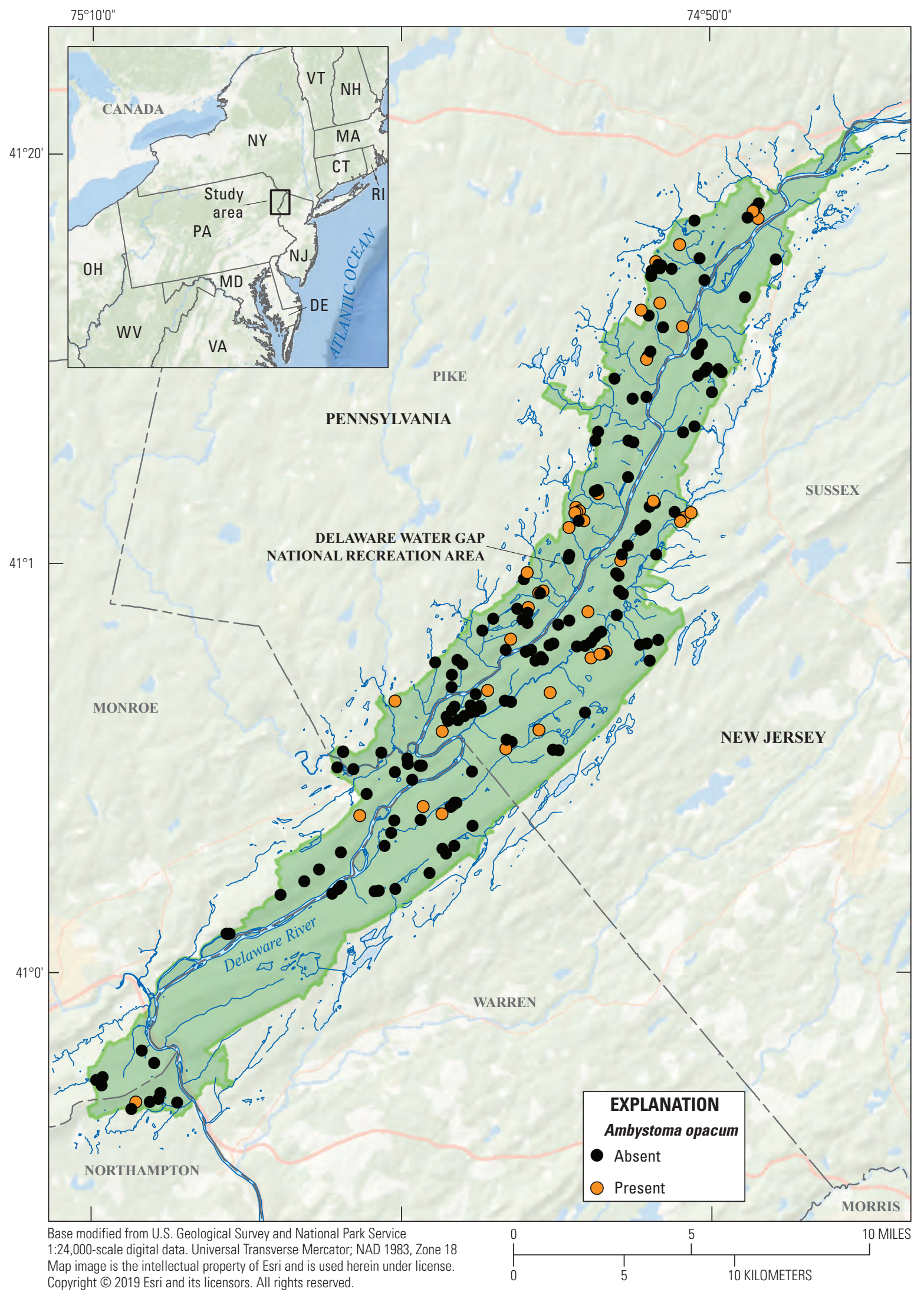

Figure 9. Location of Ambystoma opacum breeding sites in the Delaware Water Gap National Recreation Area. 


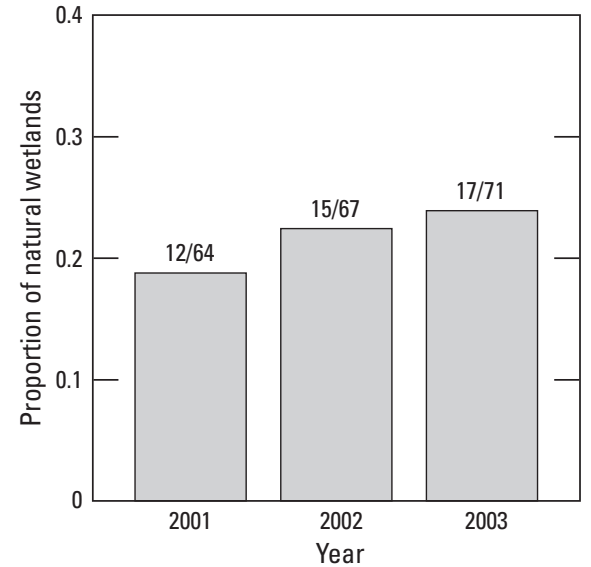

Figure 10. Proportion of randomly selected natural wetlands containing Ambystoma opacum in the Delaware Water Gap National Recreation Area. Numbers above each bar are the numbers of wetlands.

\section{Critical Breeding Habitats}

\section{Ambystoma maculatum}

Ambystoma maculatum eggs were found in 97 of the 133 (73 percent) randomly selected natural wetlands surveyed in DEWA over the 3 years of the study. The classification tree model that best explained egg mass occurrence patterns had six terminal nodes or leaves (fig. 11). Of the 18 potential predictor variables in the model, only 4 were selected by the algorithm to be used in the final tree, including hydroperiod score, primary road density within 1-km buffers, $\mathrm{pH}$, and specific conductivity (fig. 11). The four-node model had a misclassification rate of 14.3 percent. That is, 19 of the 133 wetlands were misclassified post hoc by the model. In comparison, none of the 100 null models (standardized for node size) resulted in fewer misclassification errors than the observed model; therefore, the observed model is statistically significant $(\mathrm{p}<0.01)$.
A large fraction of the variation in A. maculatum occurrence was explained by the first split on hydroperiod score. Nearly 86 percent of the sites with hydroperiod scores that were greater than 2 contained A. maculatum egg masses compared to only 41 percent of sites with hydroperiod scores of zero or one (fig. 11). The presence of primary roads within a 1-km buffer around site boundaries was also an important predictor. Nearly 94 percent (73/78) of sites with hydroperiod scores of 2 or more and with less than 5.8 meters per hectare (m/ha) of primary roads within $1 \mathrm{~km}$ contained A. maculatum. In contrast, one-half of the sites that did have primary roads within $1 \mathrm{~km}$ were not used by $A$. maculatum despite having high hydroperiod scores (greater than $\mathrm{x}$ ). Sites least likely to support $A$. maculatum breeding populations had hydroperiod scores of zero or one and $\mathrm{pH}$ less than 4.6 (fig. 11). Sites with low hydroperiod scores were likely to contain $A$. maculatum egg masses ( 78 percent) only if $\mathrm{pH}$ was greater than 4.6 and specific conductivity was between 31 and 106 .

A. maculatum egg mass abundance ranged from 0 to 1,640 egg masses among sites. The pruned regression tree model that best explained variation in egg mass abundance had six terminal nodes and used four predictor variables to explain 47 percent of the total variance. Predictor variables included in the regression tree were hydroperiod score, primary road density within $1 \mathrm{~km}$, number of other wetlands within $500 \mathrm{~m}$, and pond type (fig. 12). As with egg mass occurrence patterns, hydroperiod as measured by hydroperiod score, by itself explained a significant amount of the total variation. The mean abundance of egg masses in the 72 sites with hydroperiod scores greater than 2 was 232 compared to a mean of 65 egg masses in the 61 sites with hydroperiod scores less than or equal to 2 . In addition to having hydroperiod scores greater than 2, sites with the greatest average number of egg masses also had less than $5.8 \mathrm{~m} / \mathrm{ha}$ of primary roads within $1 \mathrm{~km}$ and had fewer than six other wetlands within $500 \mathrm{~m}$. In contrast, sites with the fewest average number of masses had hydroperiod scores of less than 1 or were leaf- or mud-bottomed ponds that were within $1 \mathrm{~km}$ of primary roads (fig. 12). 


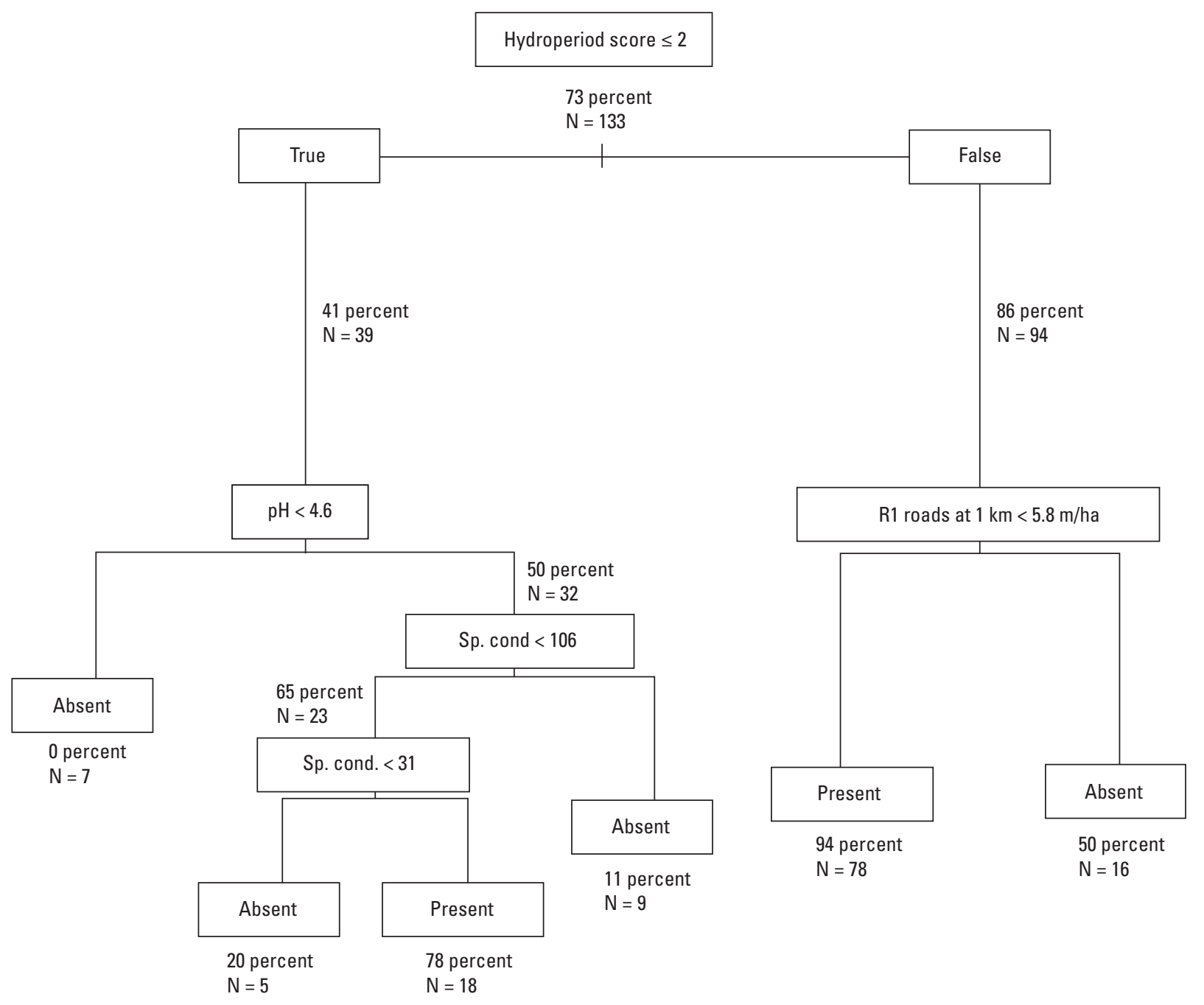

Figure 11. Pruned classification tree showing Ambystom maculatum egg mass occurrence as a function of landscape, near-pond habitat, and in-pond habitat. The habitat attribute that defines each split and its corresponding value is shown in a box at each node. Each split is represented as an inequality. If the inequality is true, proceed to the left branch of the node; otherwise proceed to the right branch. At each split, the percentage of sites containing eggs and the total number of ponds (N) are shown. Also, at terminal nodes, the model prediction (PRESENT, ABSENT) is shown. The vertical depth of each split is proportional to the variance explained by the model. [Sp. cond., specific conductivity; \%, percent; km, kilometers; $R 1$, primary roads; $m / h a$, meter per hectare; <, less than] 


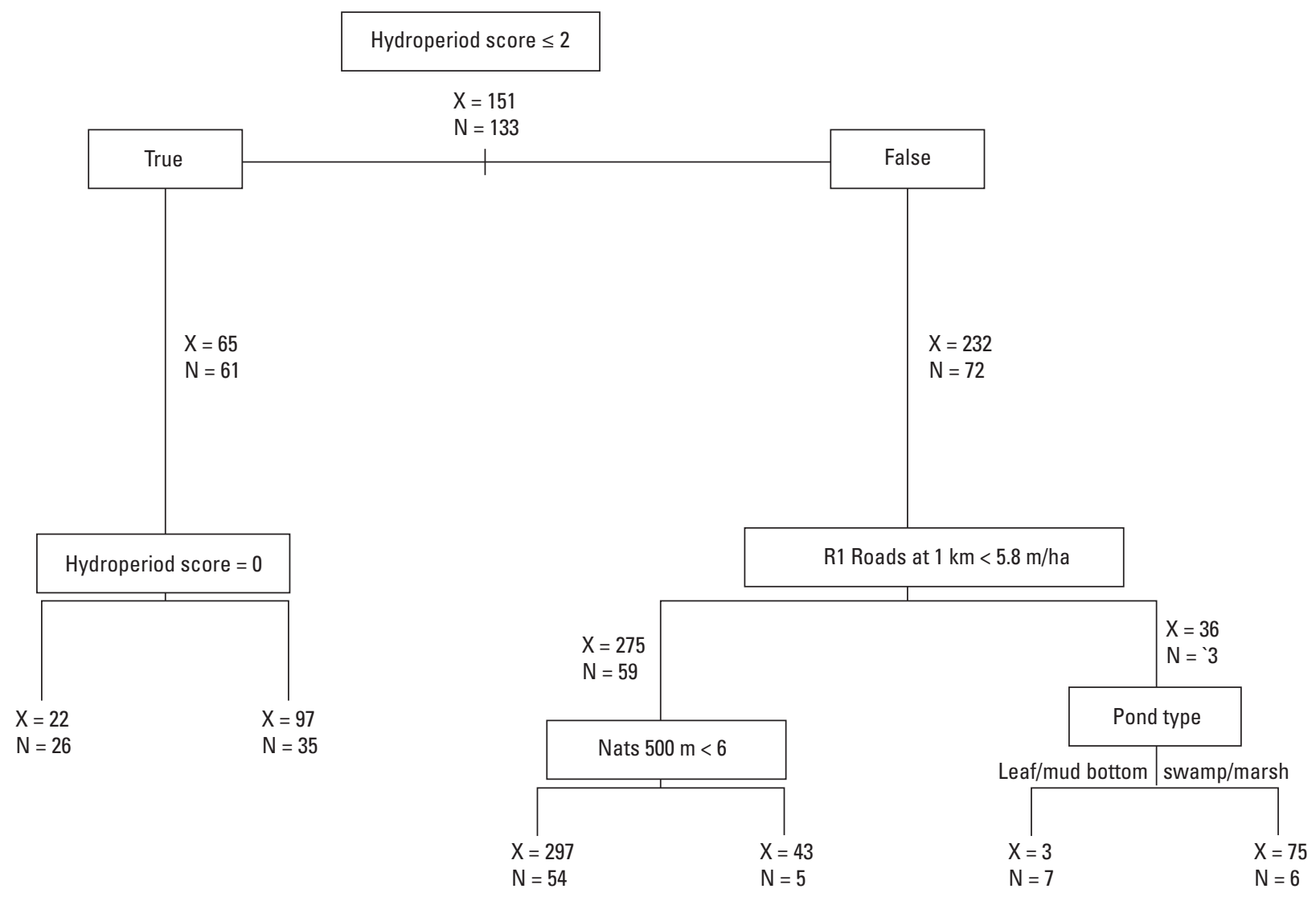

Figure 12. Pruned regression tree showing Ambystoma maculatum egg mass abundance as a function of landscape, near-pond habitat, and in-pond habitat. The habitat attribute that defines each split and its corresponding value is shown in a box at each node. Each split is represented as an inequality. If the inequality is true, proceed to the left branch of the node; otherwise, proceed to the right branch. At each split, mean egg mass abundance $(\mathrm{X})$ and the total number of ponds $(\mathrm{N})$ are shown. The vertical depth of each split is proportional to the variance explained by the model. [Nats, natural wetlands; $m$, meter; km, kilometers; $\mathrm{m} / \mathrm{ha}$, meter per hectare; $\mathrm{R} 1$ roads, primary roads; <, less than]

\section{Ambystoma jeffersonianum}

Ambystoma jeffersonianum eggs were found in 11 of 130 randomly selected natural wetlands surveyed in DEWA over the 3 years of the study. The classification tree (fig. 13) model that best explained egg mass occurrence patterns had six terminal nodes and used 5 of the 17 potential predictor variables to explain $A$. jeffersonianum occurrence patterns. Predictor variables were primary road density within a $1-\mathrm{km}$ buffer, hydroperiod score, number of other wetlands within both 500-m and 1-km buffers, and specific conductivity (fig. 13). The misclassification rate of the observed model was 5.4 percent (7/130). In comparison, 10 of 100 null models that were generated had misclassification error rates that were lower than those of the observed model. Thus, the model was only marginally significant statistically (that is, $P=0.10$ ).

A. jeffersonianum egg mass abundance ranged from 0 to 5,448 at randomly selected natural wetlands. The pruned regression tree model that best explained variation in egg mass abundance had five terminal nodes and used four predictor variables to explain 45 percent of the total variance (fig. 14). Unlike A. maculatum for which the suites of predictors that explained occurrence and abundance of egg masses were essentially the same, there were some important differences between the predictors selected to explain occurrence (fig. 13) and those used to explain egg mass abundance (fig. 14). For example, $\mathrm{pH}$ was an important predictor of egg mass abundance but not egg mass occurrence. The 27 sites with $\mathrm{pH}$ greater than 6.6 averaged 279 egg masses compared to 12 egg masses for sites with $\mathrm{pH}$ less than 6.6 (fig. 14). Also, although sites containing primary roads within a $1-\mathrm{km}$ buffer tended to not be used by $A$. jeffersonianum, the abundance of egg masses tended to be much lower in sites with either primary or secondary roads within $1-\mathrm{km}$. The seven sites with $\mathrm{pH}$ greater than 6 and with no primary or secondary roads within $1-\mathrm{km}$ buffers contained an average of 1,066 egg masses (fig. 14). The only other sites that supported relatively large populations of $A$. jeffersonianum (mean=105 masses, $\mathrm{N}=11$ sites) had $\mathrm{pH}$ less than 6.6, fewer than 12 other natural wetlands within 1 $\mathrm{km}$, and hydroperiod scores of less than 4 (fig. 14). 


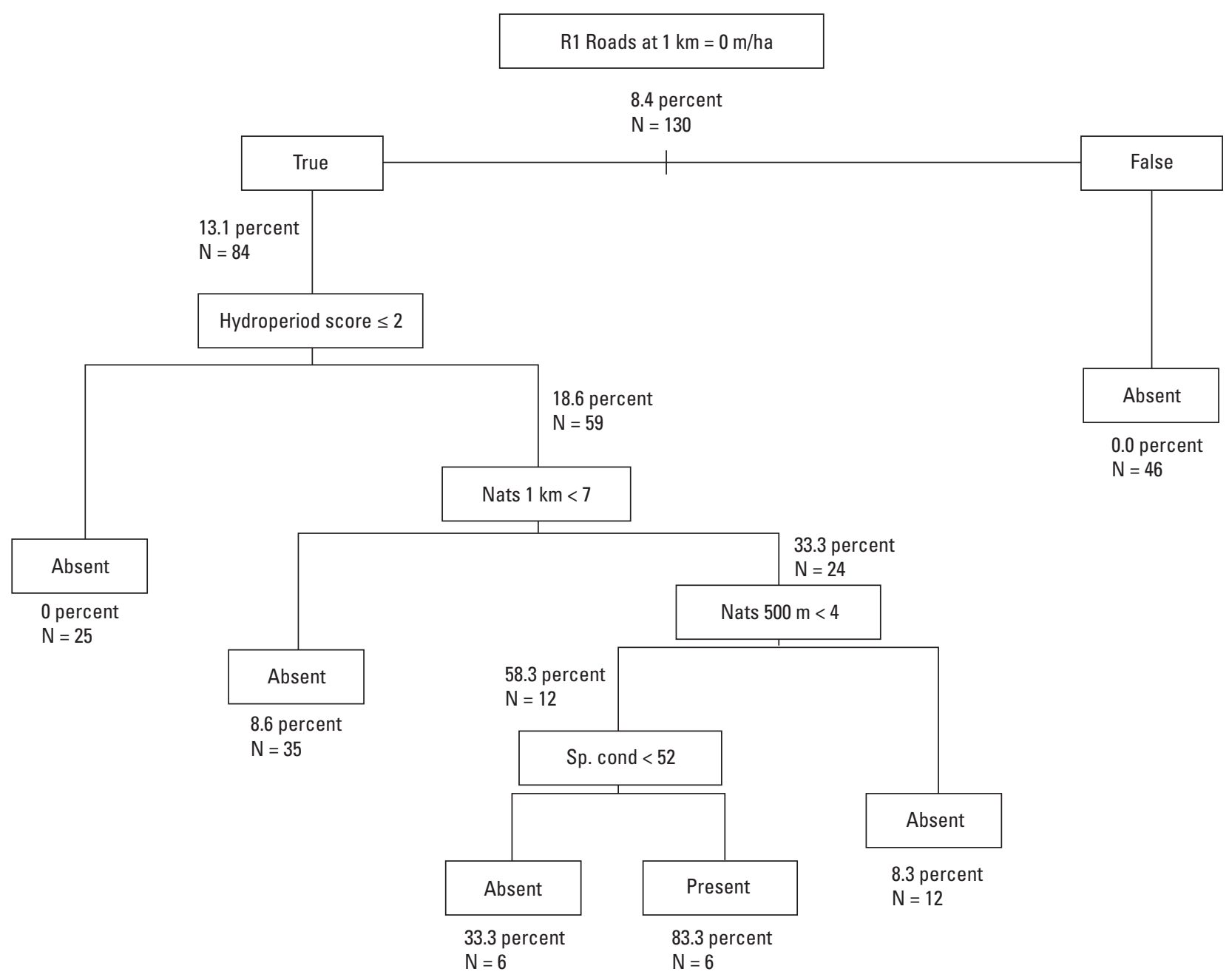

Figure 13. Pruned classification tree showing Ambystoma jeffersonianum egg mass occurrence as a function of landscape, near-pond habitat, and in-pond habitat. The habitat attribute that defines each split and its corresponding value is shown in a box at each node. Each split is represented as an inequality. If the inequality is true, proceed to the left branch of the node; otherwise proceed to the right branch. At each split, the percentage of sites containing eggs (\%) and the total number of ponds (N) are shown. Also, at terminal nodes, the model prediction (PRESENT, ABSENT) is shown. The vertical depth of each split is proportional to the variance explained by the model. [R1 Roads, primary roads; $\mathrm{km}$, define; $\mathrm{m} / \mathrm{ha}$, meter per hectare; $\mathrm{Sp}$. cond., specific conductivity; Nats, define; $\mathrm{km}$, kilometer; <, less than; $\leq$, less than or equal to] 


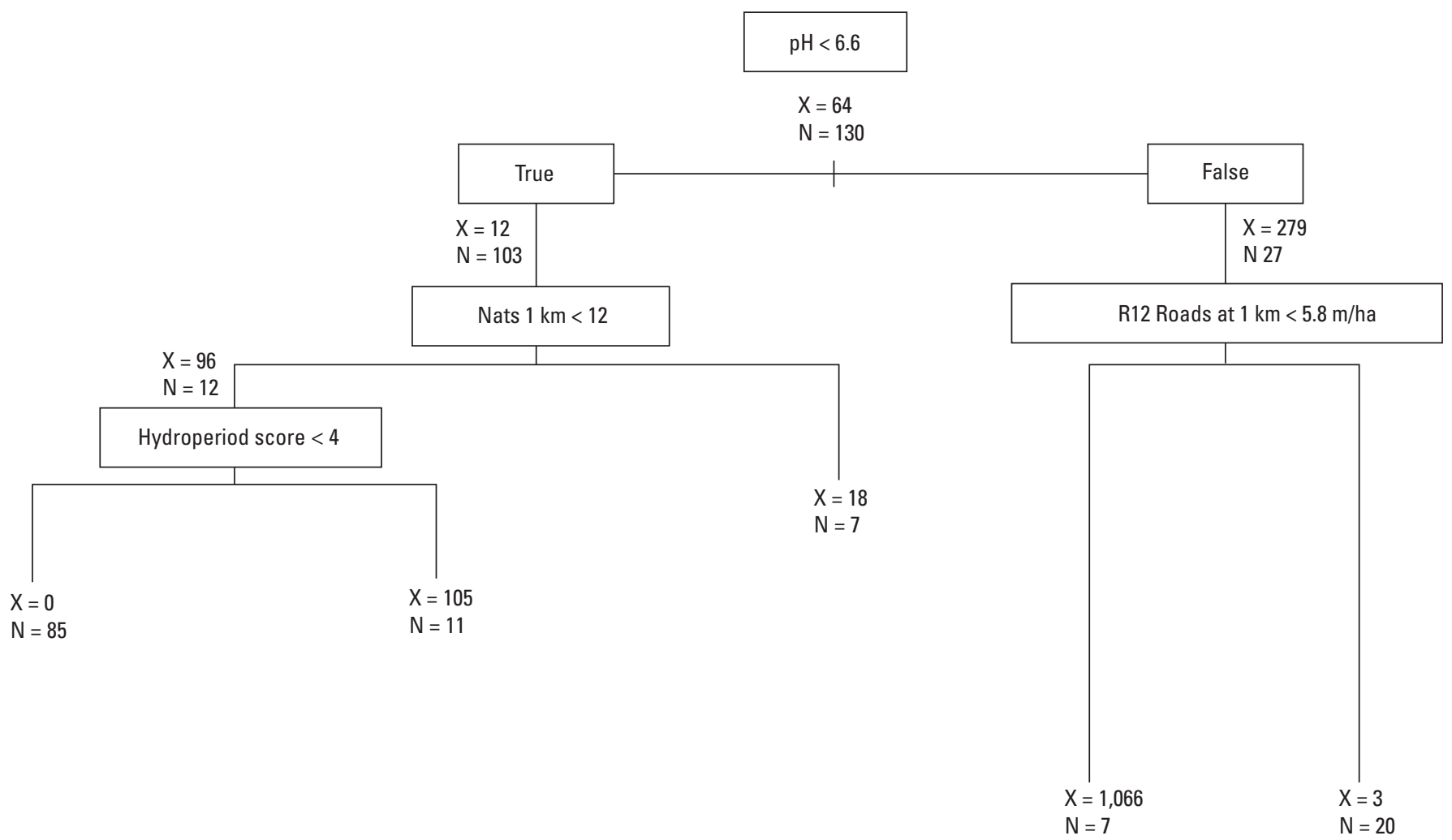

Figure 14. Pruned regression tree showing Ambystoma jeffersonianmum egg mass abundance as a function of landscape, near-pond habitat, and in-pond habitat. The habitat attribute that defines each split and its corresponding value is shown in a box at each node. Each split is represented as an inequality. If the inequality is true, proceed to the left branch of the node; otherwise proceed to the right branch. At each split, mean egg mass abundance $(X)$ and the total number of ponds $(N)$ are shown. The vertical depth of each split is proportional to the variance explained by the model. [Nats, natural wetlands; $\mathrm{km}$, kilometer; $\mathrm{m} / \mathrm{ha}$, meter per hectare; R12 Roads, primary and secondary roads; $<$, less than]

\section{Ambystoma opacum}

Ambystoma opacum larvae were observed in 33 of 133 (25 percent) randomly selected natural ponds and wetlands. The classification tree model (fig. 15) that best explained A. opacum egg mass occurrence had six terminal nodes and used 5 of the 17 potential predictor variables. The model had a misclassification error rate of 12.8 percent (17/133). In comparison, none of the randomly generated null models, standardized for comparable node size, had fewer errors than the observed models (that is $P<0.01$ ).

Ambystoma opacum tended to avoid sites near roads. Specifically, A. opacum larvae were observed in only 6 of the 62 sites that contained either primary or secondary roads within $1 \mathrm{~km}$. Of those sites with low road density, A. opacum larvae were not found in any of the 16 sites with short hydroperiods (hydroperiod score less than or equal to 2) and low $\mathrm{pH}$ (less than 5) (fig. 15). Sites with a high likelihood of supporting A. opacum either had low road density, short hydroperiods (hydroperiod score less than or equal to 2), high $\mathrm{pH}$ (greater than 5), and numerous other wetlands within $1 \mathrm{~km}$ (greater than or equal to 10) or had low road density, long hydroperiod (greater than 2), and low specific conductivity (less than 55) (fig. 15).

However, as stated earlier and in contrast to the other two species, high turnover rates for $A$. opacum were observed. As a result, larvae are more likely to be observed in sites sampled more frequently (that is, in multiple years) than sites sampled in only 1 year. Moreover, because habitat attributes of sites with turnover were essentially unchanged from year to year, variation in sampling frequency could introduce a bias that might make any inferences regarding occurrence-habitat associations suspect.

To evaluate the potential effects of bias associated with sampling sites with different sampling frequencies, first, the relation between sampling frequency and probability of occurrence of A. opacum larvae was examined. As expected, sites sampled more often were more likely to contain $A$. opacum larvae than sites sampled in only 1 year (fig. 16). However, the association between sampling frequency and occurrence was relatively weak, and observed differences were marginal statistically (Fisher's Exact Contingency Test, $\chi^{2}=2.59$, $\mathrm{df}=1, P=0.12)$. 
Second, the sampling frequency distributions among the terminal nodes of the classification tree model were compared (fig. 15). If the sampling frequency bias was important in the classification model, $A$. opacum occurrence probabilities would be expected to be higher for those nodes containing a higher frequency of sites that were sampled in multiple years, compared with nodes containing more sites sampled in only 1 year. Four of the six terminal nodes were found to have sampling frequency distributions very similar to the overall sampling frequency of all 133 sites (that is, approximately 82 percent sampled in only 1 year; 18 percent sampled in more than 1 year) (table 6). Of these 4 terminal nodes, 3 had low occurrence probabilities ( $0-22$ percent) and 1 (node 4$)$ had the highest $A$. opacum occurrence probability ( 88 percent) (table 6). The two other terminal nodes had a substantially higher frequency of sites sampled more than one year (greater than 31 percent). One of the two nodes (node 3 ) had a high probability of containing A. opacum ( 80 percent), and the other node (node 5 ) had a relatively low probability of containing A. opacum (27 percent) (table 6). Thus, although there is clearly a bias associated with sampling frequency, the bias appears to be relatively equally represented among the nodes in the classification tree regardless of occurrence probability.

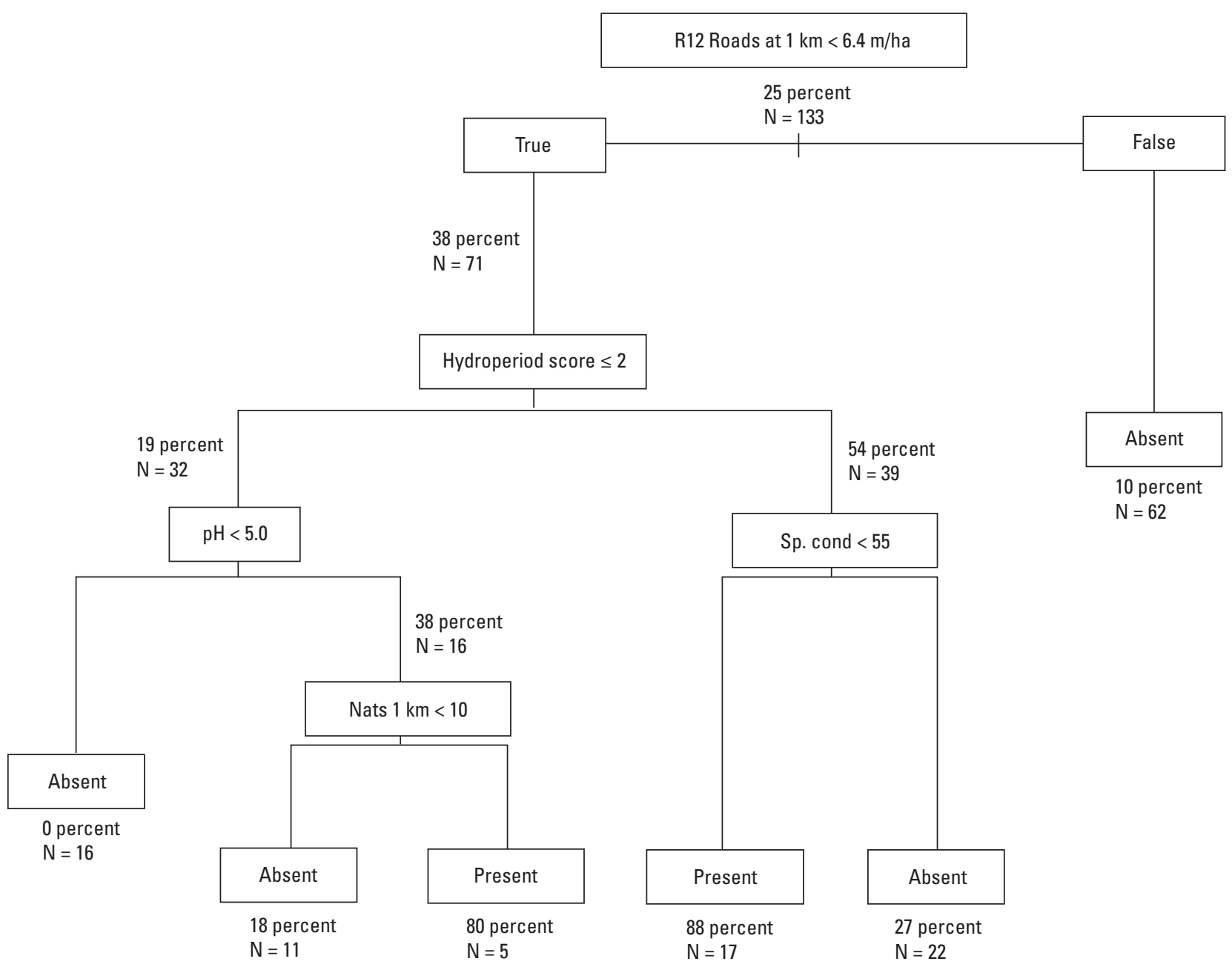

Figure 15. Pruned classification tree showing Ambystoma opacum egg mass occurrence as a function of landscape, near-pond habitat, and in-pond habitat. The habitat attribute that defines each split and its corresponding value is shown in a box at each node. Each split is represented as an inequality. If the inequality is true, proceed to the left branch of the node; otherwise, proceed to the right branch. At each split, the percentage of sites containing eggs (\%) and the total number of ponds (N) are shown. Also, at terminal nodes, the model prediction (PRESENT, ABSENT) is shown. The vertical depth of each split is proportional to the variance explained by the model. [R12 Roads, primary and secondary roads; $\mathrm{km}$, kilometers; $\mathrm{m} / \mathrm{ha}$, meter per hectare; km, kilometer; Nats, natural wetlands; Sp. cond., specific conductivity] 
Table 6. Sampling frequency and Ambystoma opacum occurrence probabilities among classification tree terminal nodes.

[See figure 14 for terminal tree nodes. Table shows the percent of sties sampled in only 1 year, percent of sites sampled in 2 or 3 years, and sample sizes of each node]

\begin{tabular}{|c|c|c|c|c|c|}
\hline & \multirow{2}{*}{ Node } & \multirow{2}{*}{$\begin{array}{l}\text { Percent of sites with } \\
\text { larvae }\end{array}$} & \multirow{2}{*}{ No. of sites } & \multicolumn{2}{|c|}{ Percent of sites in each node sampled } \\
\hline & & & & 1 year & 2-3 years \\
\hline & Root & 25 & 133 & 83 & 17 \\
\hline 1 & & 10 & 16 & 81 & 19 \\
\hline 2 & & 18 & 11 & 82 & 18 \\
\hline 3 & & 80 & 5 & 60 & 40 \\
\hline 4 & & 88 & 17 & 82 & 18 \\
\hline 5 & & 27 & 22 & 68 & 32 \\
\hline 6 & & 10 & 62 & 89 & 11 \\
\hline
\end{tabular}

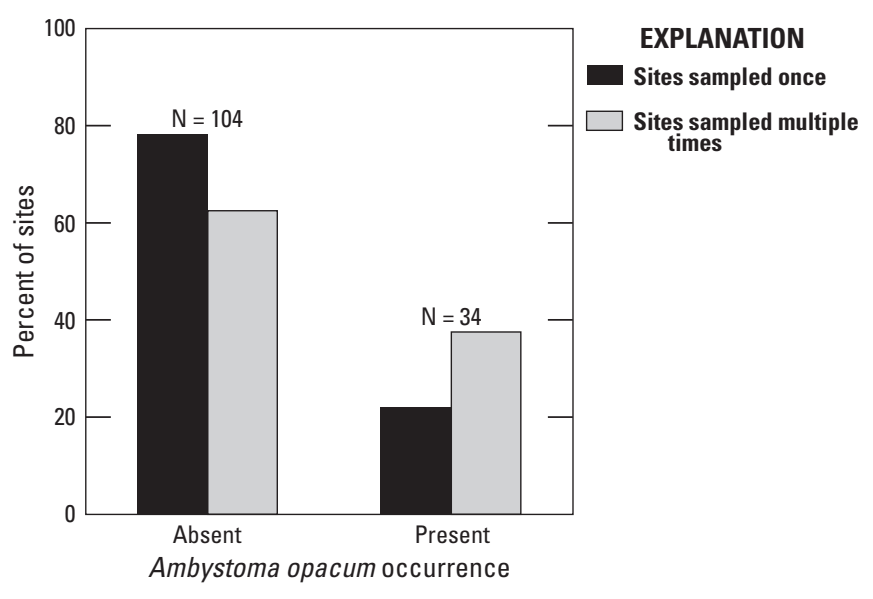

Figure 16. Ambystoma opacum occurrence at sites sampled in only 1 year and sites sampled in 2 or 3 years. Numbers above each set of bars represent the total number of sites.

\section{Effects of Impoundments}

In addition to seasonally flooded wetlands and temporary ponds, all three ambystomatid species bred in permanent natural bodies of water as well. However, only A. maculatum bred in a significant number of artificial impoundments. A. maculatum breeding sites $(\mathrm{N}=132)$ were distributed among natural sites and impoundments in roughly the same proportions as they occurred in all 200 sites surveyed (fig. 17). In contrast, A. opacum larvae were observed in only one of the 29 impoundments sampled, and $A$. jeffersonianum egg masses were never observed in impoundments, though they were observed in permanent natural wetlands (fig. 17).

Fish were observed in 22 percent of all sites surveyed (fig. 18), including 13 percent of natural wetlands and 79.3 percent of impoundments. The occurrences of all three species of salamanders were negatively correlated with the presence of fish. Only 1 of the 20 identified breeding sites for A. jeffersonianum contained fish, and fish were observed at that site (site 80 ) in only 1 of the 3 years the site was sampled. Moreover, the site is known to dry up completely in dry years (as it did in 2002), indicating a resident fish population or community is unlikely. The proximity of site 80 to a major road leads to the belief that the presence of fish at this $A$. jeffersonianum breeding site in 2001 was likely due to someone purposefully releasing fish into it, perhaps as bait. Fish presence also seems to have a strong effect on $A$. opacum and $A$. maculatum presence. Sites without $A$. opacum contained fish 25 percent of the time, whereas only 10 percent of sites with A. opacum contained fish. Furthermore, $A$. opacum were found in less than 9 percent of sites containing fish, compared to 23 percent of fishless sites. Sites without A. maculatum contained fish 37 percent of the time, whereas only 15 percent of sites with A. maculatum contained fish.

The presence of fish negatively affected the presence and relative abundance of $A$. maculatum in 2001 and 2002. In 2001, A. maculatum bred in more than 60 percent of fishless sites but in only 40 percent of sites with fish. In 2002, $A$. maculatum bred in nearly three-quarters of fishless sites and in less than one-half of sites with fish (fig. 19). As with pond type, differences in the proportion of sites occupied, with fish and fishless, were more pronounced when comparing large populations. Large breeding populations of $A$. maculatum were found in approximately 27 percent of fishless sites and 12 percent of sites with fish in 2001, and 23 percent of fishless sites and 12 percent of sites with fish in 2002 (fig. 19).

Logistic regression results indicate that site type and fish presence had similar effects on A. maculatum egg mass occurrence in 2001 and 2002. After accounting for the effects of site type, sites without fish were about 2.5 times more likely to have A. maculatum egg masses than sites with fish in 2001 $(\beta=0.442, P=0.10, \mathrm{df}=1)$ and $2002(\beta=0.472, P=0.10$, $\mathrm{df}=1)$. In contrast, after accounting for the effects of fish presence, site type had no effect on egg mass abundance in either $2001(\beta=-0.120, P=0.69, \mathrm{df}=1)$ or $2002(\beta=-0.003$, $P=0.99, \mathrm{df}=1)$ (fig. 20). Furthermore, logistic regression 
models predicted egg mass abundances to be highest in natural fishless sites, followed by fishless impoundments, natural sites with fish, and impoundments with fish in both 2001 and 2002.

Because the 2002 study year was extremely dry (fig. 2), there were fewer natural wetlands available for breeding. However, it is unlikely that any of the impoundments in the Park dried up completely. Consequently, investigators were interested in whether the use of impoundments by A. maculatum increased in 2002 in response to the drought. The below average precipitation in DEWA prior to spring 2002 resulted in 25 of 29 natural sites having smaller pond areas in 2002 than in 2001, which could have affected A. maculatum breeding patterns. In natural sites, a strong correlation was observed between changes in A. maculatum egg mass counts and changes in pond area (Spearman: $\mathrm{r}=0.829, P<.0001, N=22$ ). A comparison of changes in egg mass counts between years showed that 71 percent of natural sites with $A$. maculatum decreased in mass counts (17 of 24 sites) from 2001 to 2002, whereas only 43 percent of impoundments with $A$. maculatum decreased in mass counts ( 3 of 7 sites). Results of Sign tests indicate that the number of sites with breeding populations that decreased from 2001 to 2002 was significantly greater than expected by chance for natural sites (Sign Test, $P=0.06$ ) but not for impoundments (Sign Test, $=0, P=1.00$ ).

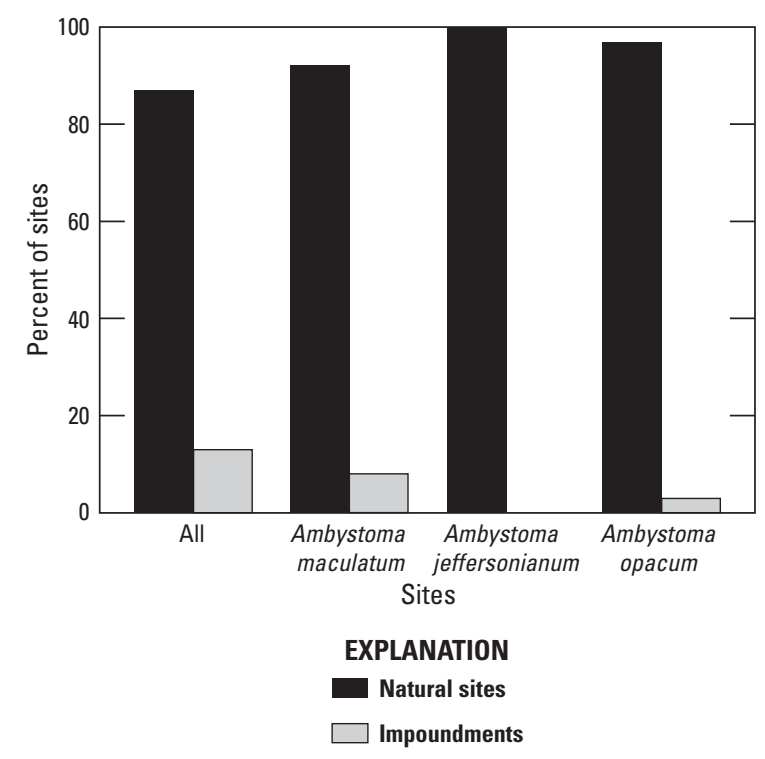

Figure 17. Percent of wetlands and impoundments used for breeding by the three ambystomatid salamander species and the percent of all natural wetlands and impoundments available on the landscape, Delaware Water Gap National Recreation Area. [All, all available sites]

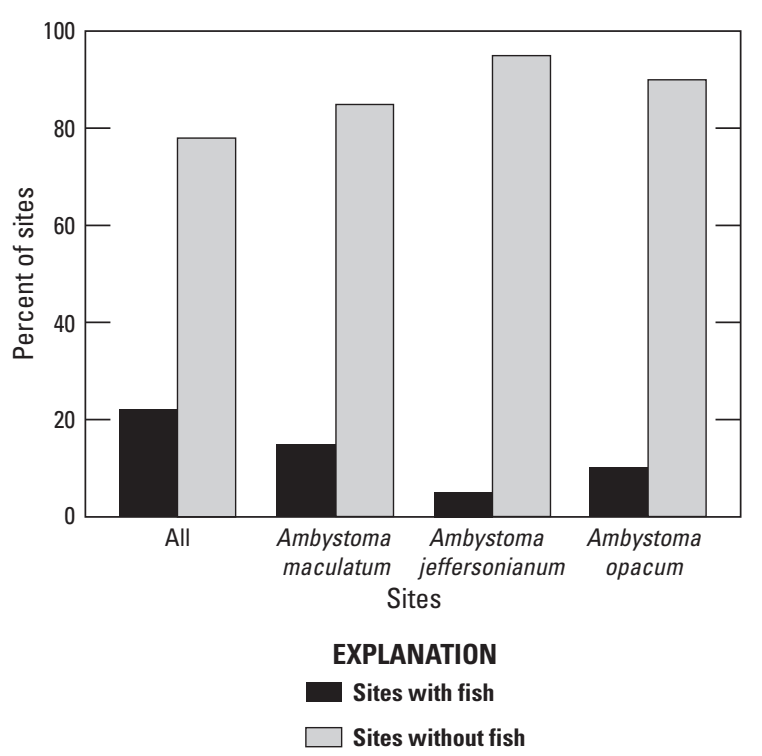

Figure 18. Percent of sampled sites and all sites with and without fish used for breeding by the three ambystomatid salamander species, Delaware Water Gap National Recreation Area. [All, all available sites]

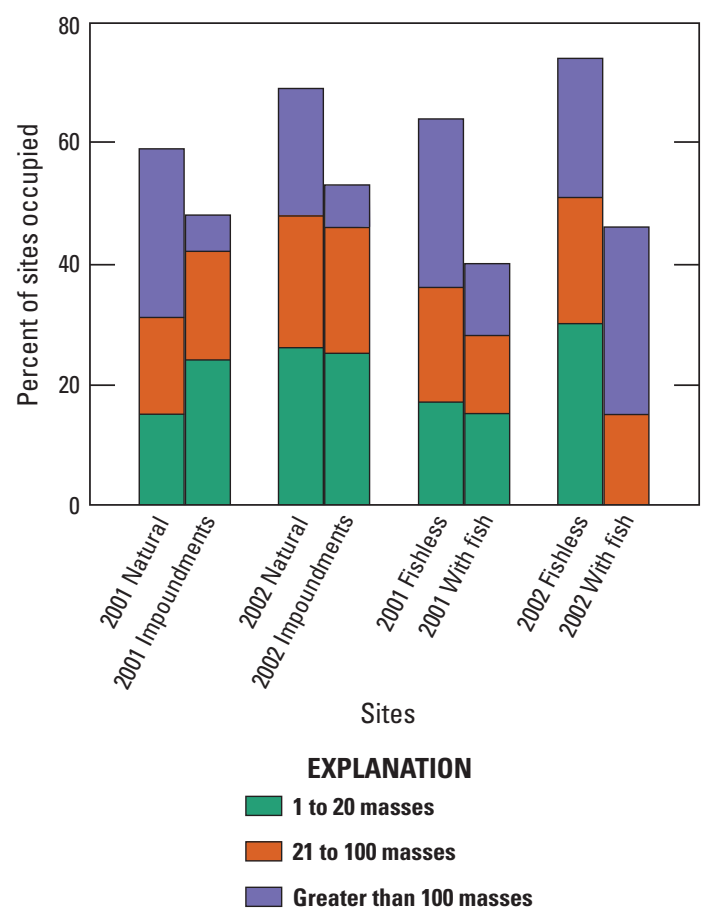

Figure 19. Percent of sites with Ambystoma maculatum egg masses as a function of site type, impoundment or natural wetland, and fish presence/ absence, Delaware Water Gap National Recreation Area, 2001-02. 


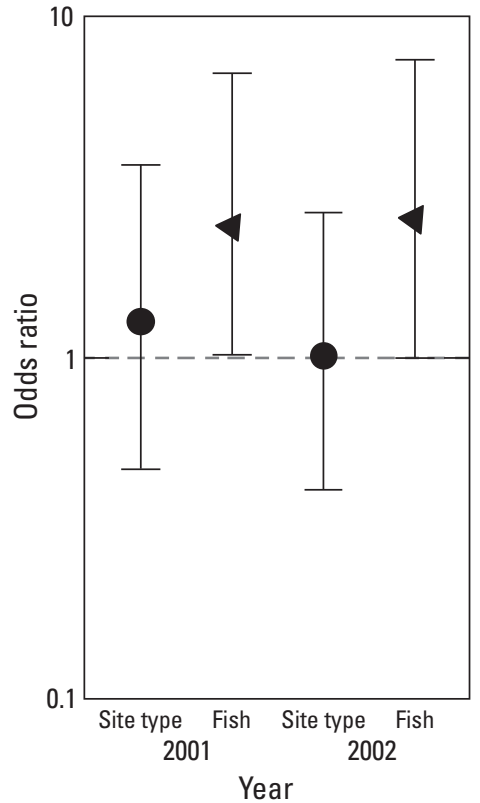

Figure 20. Results of logistic regression analysis to determine the effects of site type and fish on Ambystoma maculatum breeding site selection in the Delaware Water Gap National Recreation Area, 2001 and 2002. The dotted line at odds ratio of 1.0 indicates equal odds of containing egg masses between treatments specified by site type (natural wetlands vs impoundments) and fish (presence or absence of fish). Error bars represent 95-percent confidence limits on odds ratio estimates.

\section{Discussion}

\section{Status and Critical Breeding Habitats of Salamander Populations}

Critical breeding habitats varied considerably among the three Ambystomatid salamanders evaluated in DEWA. The differences among species and the implications for long-term viability are described below.

\section{Ambystoma maculatum}

Ambystoma maculatum was the most frequently encountered ambystomatid salamander during this study, as well as during previous surveys of wetlands in DEWA. Although considerable variation in A. maculatum egg mass production was found among years, known populations rarely failed to breed unless sites were dry during the breeding season, which did occur at numerous known breeding locations in spring 2002. Breeding populations were present in all historical breeding sites for this species and in sites where previous surveys failed to detect them. Although A. maculatum breeding was observed at a larger fraction of wetlands than in previous surveys, and although $A$. maculatum were observed at a large fraction of sites where they were not previously observed, it is not appropriate to conclude that A. maculatum has expanded its range in DEWA because sampling protocols in previous surveys were less intense. Specifically, most of the ponds or wetlands in previous surveys were visited only once during the spring breeding season compared to a minimum of three site visits each year in this study. As a result, previous surveys may have failed to observe breeding when it occurred in some instances. Nevertheless, the combined information from this study and previous studies indicates that A. maculatum has been, and continues to be, both abundant and widely distributed throughout the Park. These patterns combined with the low turnover rates between successive years indicate that the large population within DEWA is stable and requires no immediate management action directed at maintaining population viability in the Park.

In terms of breeding habitats, $A$. maculatum was found to be more of a generalist than the other two species, breeding in all types of habitats including human-made impoundments, although breeding adults tended to avoid impoundments with fish. Nearly all the wetlands with longer hydroperiods and relatively low densities of primary roads within $1 \mathrm{~km}$ of the site were used for breeding. Wetlands with these attributes are common in DEWA, representing about 62 percent of all available natural wetlands.

Even wetlands with shorter hydroperiods were frequently used by A. maculatum for breeding, as long as the water chemistry was suitable. Specifically, 78 percent of wetlands with short hydroperiods (hydroperiod score less than or equal to 2) were used for breeding when $\mathrm{pH}$ was greater than 4.6 and specific conductivity was between 21 and 106. Sites with these habitat attributes were relatively rare in DEWA, representing only slightly more than 14 percent of available natural wetlands. Short hydroperiod sites were used much less often (0-20 percent of the time) when $\mathrm{pH}$ was lower or specific conductivity was more extreme. These patterns combined with the observation that natural sites with longer hydroperiods tended to be used for breeding independent of water chemistry indicates that growth, development, or survival of eggs or larvae is compromised by low $\mathrm{pH}$ or more extreme specific conductivity levels, but longer hydroperiods may moderate these stresses in some way.

Ephemeral wetlands make good breeding habitats for amphibians because they typically do not contain fish that prey on their larvae. The tradeoff however is that amphibians that use seasonally flooded wetlands must grow and develop rapidly or they will not mature before pond drying (Semlitsch, 1987). Thus, any stress that reduces growth or increases time to metamorphosis decreases the likelihood that an individual would survive the larval period. Previous field and laboratory 
experiments have shown that low $\mathrm{pH}$ (less than 5) causes significant declines in embryonic survival and larval growth rates of ambystomatid salamanders (Sadinski and Dunson, 1992; Kutka, 1994; Horne and Dunson, 1995). Previous research has also noted that $A$. maculatum egg deposition was inversely associated with specific conductivity (Rowe and Dunson, 1993; Bunnell and Zampella, 1999). However, data from comparative field surveys indicate that survival of natural populations exposed to low $\mathrm{pH}$ is highly variable (Cook, 1983; Portnoy, 1990), supporting the argument that other factors such as hydroperiod probably interact with water chemistry to affect reproductive success in ambystomatid salamanders. Semlitsch (1987) observed a similar pattern where the effects of intraspecific competition among A. talpoideum (mole salamander) larvae depended on hydroperiod. He stated that competition for food had an effect similar to low $\mathrm{pH}$ in that it reduced growth and increased time to metamorphosis, but these effects were less consequential in ponds with long hydroperiods because individuals had enough time to develop despite lower growth rates associated with competition.

It does not necessarily follow that factors that affect breeding site selection (as inferred by presence-absence data) are the same factors that affect population abundance (as inferred by total number of egg masses). If, for example, terrestrial habitat variables were more responsible for regulating overall population size but in-pond habitat variables were more important in determining breeding site selection by mie adults, a different set of habitat predictors might be found to explain variation in occurrence and variation in abundance. However, for A. maculatum, the intensity of breeding as inferred by the total number of egg masses laid at a site was strongly related to the same two primary habitat variables as those related to pond use (presence/absence). Hydroperiod and the density of primary roads within $1 \mathrm{~km}$ explain much of the variation in egg mass abundance among breeding sites. The finding that hydroperiod was the most important predictor of both egg mass occurrence and abundance is not surprising considering the wealth of past research documenting the importance of hydroperiod to ambystomatid populations (Pechmann and others, 1989; Rowe and Dunson, 1995; Paton and Crouch, 2002). Although not as well studied, recent evidence indicates that road density negatively affects ambystomatid salamanders (Fahrig and others, 1995; Lehtinen and others, 1999; Houlahan and Findlay 2003).

\section{Ambystoma jeffersonianum}

In contrast to the relatively ubiquitous $A$. maculatum, $A$. jeffersonianum egg masses were rarely encountered, occurring at less than 10 percent of available natural wetlands. Moreover, except for the sites within the Camp Kittatiny area, populations at breeding sites were relatively small as inferred by numbers of egg masses. However, on the basis of the data from previous surveys, it appears that $A$. jeffersonianum is no less common, and their breeding populations no smaller now, than in years past. Despite the apparent persistence of
A. jeffersonianum populations in DEWA, there likely is cause for concern about the status and likelihood of persistence of the population in the future. The high incidence of LJJ biotypes, the patchy nature and small sizes of most breeding populations, and the almost non-existent gene flow among breeding populations, all indicate that the long-term outlook for A. jeffersonianum may be uncertain and that DEWA management might consider additional monitoring of the population. These factors are discussed in detail below.

Egg mass mortality in DEWA populations of $A$. jeffersonianum was considerably higher than has been reported by others for purely diploid populations of $A$. jeffersonianum and for other species of Ambystoma (Rowe and Dunson, 1993; Brodman, 1995; Cook, 1983; Julian, 2000). This high amount of mortality can be attributed to the presence of LJJ biotypes. During breeding, these purely female triploids require sperm from diploid male $A$. jeffersonianum to stimulate meiosis but do not incorporate the associated genetic material and pass it along to their offspring (Bogart and Lecht, 1987).

In A. jeffersonianum populations with only diploid (JJ) individuals, male:female ratios are typically greater than 3:1 (Petranka, 1998), but in populations where diploid and unisexual populations are sympatric, male:female ratios can be less than 1:10 (Nyman and others, 1988). When this occurs, egg mortality is typically very high owing to insufficient insemination of both JJ and LJJ females (Petranka, 1998). Triploid populations have been previously reported in western New Jersey (Nyman and others, 1988), and genetic data collected for this study confirmed the presence of large numbers of LJJ individuals in many of the A. jeffersonianum breeding sites (Julian and others, 2003).

Very high proportions (as much as 100 percent) of many DEWA breeding populations were estimated to be made up of LJJ biotypes as inferred by embryo mortality. The effect of these triploid biotypes on breeding populations is unclear but obviously has the potential to be dramatic given that all individuals of the triploid biotype are female and therefore compete with a smaller number of diploid females for male sperm. Moreover, the triploid biotype has a numerical advantage over the diploid form because all females lay eggs. These patterns indicate that the diploid form may be vulnerable to "swamping" by the unisexual form, and because the mortality rates of the unisexual biotype will continue to rise as the male:female ratio declines, the overall population would become increasingly vulnerable to extinction through time. However, although limited data are available to make strong conclusions, there is some evidence that the elimination of the diploid form by the unisexual form is not occurring. Specifically, Nyman (1979) measured the proportion of JJ and LJJ individuals in two ponds in 1978 that were also monitored during 2001-03. A comparison of the two surveys indicates that breeding populations at neither pond has declined and that the fraction of LJJ biotypes has not increased, indicating that the elimination of $A$. jeffersonianum by unisexual "swamping" has not occurred, perhaps because aspects of each biotype's reproductive ecology would alternately favor them over 
time. These data also indicate that population size and LJJ:JJ ratios at a breeding site may fluctuate over time as conditions alternately favor each biotype.

The specific conditions that favor the alternative biotypes and consequently allows for the long-term persistence of both biotypes is not clear, but two alternative hypotheses are based on temporal changes in the number and viability of A. jeffersonianum egg masses over the 3 study years. In the second year of the study (2002), lower numbers of egg masses were observed; yet higher proportions of viable egg masses were observed than during the other 2 years. Decreases in A. jeffersonianum egg mass abundance during 2002 were comparable to observations for Ambystoma maculatum in DEWA and were correlated with declines in pond areas between 2001 and 2002 that were associated with a severe drought that occurred during the spring and summer. In the following year (2003), A. jeffersonianum breeding populations again increased in size and decreased in viability. One hypothesis to explain this pattern is that male:female sex ratios increase in response to drought because females may be less likely to breed than males or that males are more persistent in terms of attempting to breed than females in the face of poor environmental conditions. Since $A$. jeffersonianum males can breed every year and females cannot (Downs, 1989), the "cost" of a failed reproductive effort is relatively greater for females. Therefore, if females are less likely than males to risk the potential costs of breeding during drought conditions, one would expect to see higher proportions of viable egg masses during drought years because typically low male:female ratios would be increased and consequently relatively more sperm would be available for fertilizing females of both biotypes.

An alternate hypothesis to explain the persistence of both biotypes within breeding populations relates to the timing of breeding migrations. In addition to the drought that occurred during spring and summer 2002, the preceeding winter was unusually warm with relatively little snow cover. As a result, ponds thawed early, and the onset of A. jeffersonianum breeding occurred 2-3 weeks earlier in 2002 than in the other 2 years. Unisexual embryos typically have higher mortality rates than JJ embryos, and adult LJJ are less successful at competing for breeding male JJ than female JJ. However, female LJJ typically compensate by migrating to breeding sites earlier than female JJ, thus affording them a competitive edge in initially sequestering male JJ sperm. Because the breeding season in 2002 was earlier than in 2001 and 2003, the lag time between female LJJ and female JJ migrations may have been reduced, thus limiting the competitive advantage of female LJJ in monopolizing available male JJ sperm.

Clearly much remains unknown regarding the potential effects LJJ biotypes on the long-term viability of the species in the Park, and more research is needed. It is possible that long-term genetic monitoring of both A. maculatum and A. jeffersonianum breeding populations might shed light on historical changes in population structure, gene flow, and colonization events that may help explain mechanisms that allow for the coexistence of the diploid and triploid forms. Beebee and Rowe (2001) confirm the practicality of using genetic techniques as a method of predicting population bottlenecks in populations of Bufo calamita (Natterjack toad), comparing demographic data to DNA microsatellite data. If genetic analyses were performed on populations of $A$. jeffersonianum and $A$. maculatum sharing the same breeding site, and there was evidence to indicate that a population bottleneck occurred in A. jeffersonianum but not A. maculatum, then sources of environmental stochasticity that would affect both species equally (like prolonged drought) could be ruled out as the cause of the bottleneck, and evidence would point towards more species specific mechanisms as the cause, such as deleterious effects of high ratios of LJJ:JJ.

In terms of breeding habitats, $A$. jeffersonianum did not breed in sites with certain habitat characteristics. For example, A. jeffersonianum did not breed in any artificial impoundments or in any natural wetland with primary roads within $1 \mathrm{~km}$ of the pond edge. Artificial impoundments represent about 12 percent of the potential breeding sites, and natural wetlands that contain primary roads within $1 \mathrm{~km}$ of pond boundaries represented just over 35 percent of all natural wetlands. However, unlike for A. maculatum, the suite of landscape and habitat variables measured was not particularly useful in predicting pond use by A. jeffersonianum. Although the best classification tree model of the study was statistically significant, a relatively large number (10 percent) of randomly generated null models (that is, random combinations of predictor variables) had as low or lower misclassification error rates than the study model.

Likewise, the best regression tree model derived to predict $A$. jeffersonianum egg mass abundance from landscape and site habitat was not particularly robust, explaining only 45 percent of the variability in egg mass abundance. In addition, most of that variance was explained by the amount of both primary and secondary roads within pond edges, which was found to positively correlate with egg mass density, a correlation that is most likely spurious. The most effective predictor of $A$. jeffersonianum egg mass abundance did not relate to habitat at all, but rather to the spatial location of breeding sites on the landscape, independent of habitat. Latitude by itself explained 75 percent of the total variation in egg mass abundance.

More specifically, although $A$. jeffersonianum breeding sites typically contained small breeding populations (mode $=$ less than 125 masses for all 3 years), the sites around the Kittitiny Camp area in New Jersey consistently produced high egg mass abundances. In each year of the study, one-half of the sites in the area produced greater than 2,000 masses per year, and the remaining sites produced 500-2,000 masses in at least one year in which they were surveyed. Smaller breeding populations of $A$. jeffersonianum in New Jersey included a cluster of ponds along Lower Pompey Ridge; several sites near Upper Pompey Ridge and Buttermilk Falls; and small, isolated breeding site near the Peter's Valley and Blue Mountain Lake. In Pennsylvania, a small, isolated breeding sites was observed in the north end of DEWA, less than $1 \mathrm{~km}$ south of the town of 
Milford (fig. 1), and a pair of moderate sized populations were observed at a site near National Park Service Headquarters.

However, over the 3 years of the study, the reproductive output of the 30 percent of sites in the Kittitiny Camp area $(\mathrm{N}=6)$ produced on average 89.2 percent of all $A$. jeffersonianum egg masses in the Park. Sites in this area are relatively close to secondary roads which explains the positive correlation with roads referred to above.

The reason for this spatial pattern in A. jeffersonianum in the size of breeding populations is unclear. However, landscape and in-pond habitat characteristics were clearly not, by themselves, particularly important, or the habitat models would have been more robust. That is, there does not seem to be anything unique about the Kittitiny Camp area from a habitat point of view. The observed patterns may be consistent with a metapopulation that is either expanding or contracting its range. Another possibility is that the occurrence of the triploid biotype is a relatively recent event in the Park and may be causing local extinctions for intrinsic reasons described above. Whatever the explanation, the observation that such a large fraction of this species reproductive output is centered on such a small spatial area in the Park is cause for concern and would benefit from more research.

\section{Ambystoma opacum}

Ambystoma opacum was intermediate relative to the other two species in terms of abundance of breeding sites, occurring at about 20 percent of the sites surveyed. A. opacum was present at all historical breeding sites, as well as at many sites previously surveyed but where they were not previously found. However, as with the other two species, this species was sampled with greater effort than in previous surveys, including VES over multiple visits and a relatively rigorous dipnetting at each site. Thus, the higher occurrence probability observed for A. opacum in this study compared with previous surveys does not necessarily imply an increasing population.

The relatively low occurrence frequency of $A$. opacum relative to $A$. maculatum is likely due to differences in their life history that make them more vulnerable to stochastic weather events. Specifically, because A. opacum lays eggs in dry pond beds, they require sites that dry down substantially in the summer and early fall during the egg laying period but refill again and maintain water levels long enough for hatching and larval development. Thus, A. opacum is vulnerable to extraordinarily wet summers because ponds would not dry down sufficiently for egg laying and to unusually dry winters and springs because sites would not have sufficient hydroperiod to support larval and growth and development. In contrast, $A$. maculatum requires only the latter. Thus, a much smaller set of sites would meet hydrologic conditions for successful reproduction for $A$. opacum.

In contrast to the other two species, $A$. opacum had high turnover rates at breeding sites. High turnover at individual sites was observed despite relatively consistent occurrence probabilities among years, ranging from 19 percent to
24 percent. There are two possible explanations for the high turnover rates observed at breeding sites. Either detection probabilities were relatively low leading to a high likelihood of not observing larvae when they were actually present or between-year variation in some important habitat characteristic resulted in A. opacum breeding at a site one year but not in another year, or some combination of the two.

A. opacum larval detection probabilities likely were relatively high in this study, though likely not as high as for A. maculatum and A. jeffersonianum egg masses. In all 3 years, VES and dipnetting were used to sample $A$. opacum larvae. In 2001 and 2002, all sites were dipnetted for A. opacum larvae, even sites in which larvae were detected previously during VES, whereas in 2003, dipnetting was not used at sites in which larvae had already been observed during VES. For the years 2001 and 2002, there were instances larvae were not detected using VES, but they were detected during dipnet surveys and vice versa. Also, neither technique appeared to work better than the other, although in 2002 larvae were detected in more ponds using dipnetting than using VES. In a previous study, Jenkins and others (2002) found that VES for $A$. opacum larvae during the spring resulted in an approximately 80 percent success rate when sites were visited at least three times. In this study, all sites were visited at least three times. Moreover, because dipnetting and VES were equally effective in this study, dipnetting should have a similar sampling success rate. Thus, independently employing both techniques, as in this study, should provide a success rate of approximately 95 percent for combined techniques.

The more likely explanation for the high turnover observed for A. opacum at breeding sites is related to the drought that occurred in 2002. During that year, a large fraction of sites that normally fill with water in the late fall and winter apparently did not fill until very late in the spring, and many of those filled only partially. At the same time, most instances of $A$. opacum turnover that were observed were associated with sites where larvae were observed in 2001 or 2003 but not during the 2002 drought year. This pattern indicates A. opacum eggs deposited in ponds that did not fill until the spring of 2002 may have failed to hatch. It is not clear why eggs would not continue to be viable through the winter and hatch normally in the spring. If that were to occur, larvae may be at a relative disadvantage because they would compete with, rather than prey on, A. maculatum and A. jeffersonianum larvae at sites where they are sympatric, but the presence of some A. opacum would still be expected in some samples. Sites were not visited until spring, so it is not known what the hydrologic conditions were throughout the fall and winter. It may be that many of the sites with turnover did fill early in the winter but dried up later in the season before again refilling in the spring. If so, larvae may have hatched and then died after the pond dried up again.

In terms of breeding site habitat, A. opacum almost never bred in artificial impoundments or in wetlands that contained fish. They also tended to avoid natural wetlands with either primary or secondary roads within $1 \mathrm{~km}$ of the 
pond edge. Avoidance of sites with either primary or secondary roads indicates $A$. opacum may be even more vulnerable to road traffic than the other two species that showed a negative correlation with only primary roads. It may be that $A$. opacum is less likely to migrate across any paved substrate (that is, a behavioral characteristic), whereas the observation of low pond use of sites with primary roads nearby for the other two species reflects higher than normal mortality rates from cars (that is, a population characteristic). Results of the habitat model further indicate that $A$. opacum preferred breeding sites either with long hydroperiods and low specific conductivity or, for sites with short hydroperiods, sites with high $\mathrm{pH}$ and other wetlands nearby. These patterns are comparable to those observed for A. maculatum where $\mathrm{pH}$ was negatively correlated with pond use but only in sites with lower hydroperiods, indicating that hydroperiod may ameliorate the effects of acid stress.

\section{Effects of Impoundments}

On the basis of survey data, no evidence was found that artificial impoundments provide critical or preferred breeding habitat for A. jeffersonianum or A. opacum. Although the propensity for impoundments to contain fish (23 out of 29 contained fish) likely contributed to the exclusion of A. opacum and A. jeffersonianum from these sites, static water levels of impoundments likely further deterred the colonization the $A$. opacum in these habitats because $A$. opacum require nesting sites that are dry when they deposit their eggs but later fill with water to initiate hatching of the larvae. Furthermore, artificial impoundments in DEWA likely contribute significantly to the amount of $A$. maculatum breeding habitat across the landscape because of the abundance of more suitable, fishless, natural bodies of water. Although impoundments were used frequently by $A$. maculatum for breeding, only 2 of 24 supported large breeding populations. Results indicate that the tendency for impoundments to contain fish was adequate to explain the lower occurrence and abundance of $A$. maculatum in impoundments than in natural bodies of water. Although

A. maculatum egg mass abundance was observed to decrease in natural sites between drought and non-drought years (2001 and 2002, respectively), salamanders did not colonize previously uninhabited impoundments during drought conditions, nor did their abundances in impoundments increase significantly. Therefore, impoundments likely do not offer a "rescue effect" during drought years for populations from nearby natural bodies of water that do not fill. However, owing to the limited duration of this project, the importance of these habitats to the persistence of $A$. maculatum populations during extended periods of drought could not be assessed. In addition, the conclusions regarding the potential effect of human-made ponds could not be extrapolated to landscapes where natural wetlands and ponds are less common.

In making the final decision to deactivate individual impoundments, however, DEWA resource managers may want to consider the degree in which the impoundment is isolated from other bodies of water, especially if the impoundment in question contains $A$. maculatum. Measures of isolation for impoundments occupied by $A$. maculatum are summarized in table 7. Relatively isolated impoundments (those greater than $500 \mathrm{~m}$ from other sites or those with fewer than three bodies of water within $1 \mathrm{~km}$ ) may provide the only available breeding habitat for $A$. maculatum in a given area of the Park and may prove to be important "stepping stones" in maintaining gene flow between areas with higher densities of breeding habitats that flank them.

Table 7. Measures of isolation for impoundments used as breeding sites by Ambystoma maculatum in Delaware Water Gap National Recreation Area.

[Dist., distance; km, kilometer; m, meter; >, greater than; no. number]

\begin{tabular}{|c|c|c|c|c|}
\hline Site no. & No. egg masses & Sites within 1 km & Sites within $500 \mathrm{~m}$ & Dist. to nearest site (m) \\
\hline 1250 & $1-20$ & 0 & 0 & 9,194 \\
\hline 905 & $21-100$ & 2 & 0 & 697 \\
\hline 710 & $1-20$ & 3 & 1 & 343 \\
\hline 785 & $>100$ & 1 & 1 & 222 \\
\hline 244 & $21-100$ & 3 & 2 & 220 \\
\hline 72 & $1-20$ & 7 & 4 & 217 \\
\hline 971 & $1-20$ & 6 & 6 & 145 \\
\hline 968 & $21-100$ & 6 & 5 & 145 \\
\hline 517 & $1-20$ & 7 & 1 & 126 \\
\hline
\end{tabular}




\section{Management Implications}

Results of this study have significant long-term and near-term implications for management of natural resources in DEWA. Because ambystomatid salamanders require relatively undegraded terrestrial and aquatic habitats to complete their life cycles, they make excellent indicators of overall ecosystem health (Vitt and others, 1990; Welsh and Ollivier, 1998). Consequently, should DEWA management decide to include pond-breeding salamanders into their future long-term monitoring programs (for example, Vital Signs), the assessments of current status and recent trends generated from this study likely will be invaluable in terms of baseline data. In addition to baseline information on the salamanders, this study added considerably to what was previously known about wetland habitats in DEWA. Although a significant number of wetlands in the Park had been mapped prior to this study, the location of many had not been field validated, and most had little if any associated biological and habitat data. During the period of this study, more than 250 wetlands were visited, including many that had never been mapped, and more than 30 variables were measured and linked to 200 sites, including landscape position, wetland size, hydroperiod, in-pond habitat, and amphibian occurrence and abundance patterns. This information provides an excellent baseline data layer on wetland resources in the Park that can be used as a basis to infer status and trends of this important component of the ecosystem.

This study also generated data useful for near-term management of ambystomatid salamanders in the Park. For instance, information on breeding site selection provided support for certain management prescriptions that would aid in the preservation of these species. Specifically, although there was substantial variation in wetland habitat use by the three ambystomatid salamander species, there were also several important habitat preferences that they shared. All three species tended to avoid breeding in natural wetland sites that contained primary roads within $1 \mathrm{~km}$ of wetland edges. Ambystoma opacum occurrence was negatively correlated with secondary (low traffic) paved roads as well. Currently (2020), about one-third of natural wetlands within the Park are within $1 \mathrm{~km}$ of primary roads, and more than 90 percent are within $1 \mathrm{~km}$ of a primary or secondary road. More importantly, recent trends in human population growth and associated development in the area surrounding the Park were identified. Over the last 3 decades (1991-2020), human population growth rates in the four counties of DEWA (Pike and Monroe, Pennsylvania.; Sussex and Warren, New Jersey) were the fastest growing counties in their respective States (Pennsylvania State Data Center, 2020; Cornwall Center for Metropolitan Studies, 2003). Given these trends in human population and residential development within and adjacent to Park boundaries, there may be pressure to build new roads or improve (that is, pave) existing roads and trails. Data from this study suggest that additional roads could have negative consequences for ambystomatid salamander populations within the Park. Thus, if possible, planning for new road construction or improvement could consider the location of wetlands used by breeding salamander populations, most of which have now been mapped.

Hydroperiod was the most important feature of breeding sites common to all three species. Excluding impoundments and wetlands that contained fish, A. maculatum and A. jeffersonianum preferred sites with long hydroperiods. Ambystoma opacum also tended to prefer long hydroperiod sites, as long as wetlands dried enough in summer to provide dry areas within the pond boundary in which to lay eggs. Consequently, environmental factors that reduce the amount of time that wetlands contain water could adversely affect all three species if dry conditions persisted for multiple years.

The possible increase in air temperature and drought frequency associated with human-induced increases in concentrations of greenhouse gasses (global warming) could cause reductions in wetland hydroperiods. Many regional climate change models predict warmer temperatures, especially in winter, for the northeastern United States (Hansen and others, 1988; Wetherald and Manabe, 1988). Monitoring of wetland hydroperiods and wetland assemblages over long periods of time could provide an early warning indicator of climate change and its effects in the Park. In addition, because of the relation between tree species and evapotranspiration rates (Bowden and Bauerle, 2008), climate or pest-induced changes in forest composition could also affect wetland hydroperiods.

In DEWA, one of the most important management concerns in recent years has been the decline in hemlock forests owing to the Adelges tsuga (hemlock woolly adelgid; HWA), an exotic insect native to the East Asia (Evans, 1995). Hemlock forests in DEWA have been infected with the pest since 1989, and there has been considerable HWA-induced mortality since about 2000 (R. Evans, DEWA, oral commun., 2001). In this study, the hydroperiods of the 102 natural wetlands present on forested ridges with and without significant amounts of hemlock within 200 -m pond buffers were compared. A total of 64 sites did not contain significant hemlock within the buffers, and 38 sites did contain hemlock. Vegetation maps of Myers and Irish [1981] were used to infer the presence or absence of hemlock. Although the patterns were similar for most hydroperiod ranks, the surrounding forests of sites with the shortest hydroperiods (that is, hydroperiod scores of 0 , see "Methods" section) rarely contained a significant hemlock component (fig. 21). Only 1 in 12 sites containing significant hemlock $(\mathrm{N}=3)$ had the lowest hydroperiod scores (that is, shortest hydroperiods) compared to 1 in 4 sites without hemlock $(\mathrm{N}=12)$. This pattern indicates that pest-induced hemlock decline could reduce hydroperiods and perhaps reduce the availability of ambystomatid salamander breeding habitats in the Park should hemlock forests continue to decline.

Finally, although not as important as roads or hydroperiod, the $\mathrm{pH}$ of ponds and wetlands was also found to be a significant predictor of whether, or to what extent, a site was used for breeding by all three species. Wetlands and temporary ponds are often naturally acidic owing to the presence of sphagnum moss, which is known to acidify 
waters, and to high concentrations of humic acids associated with the decomposition of plant matter (Freda and others, 1991). As a result, amphibians that use these habitats to breed have evolved relatively high tolerances to acidic conditions relative to other aquatic fauna such as fish. However, it is well documented that acidic precipitation and deposition associated with air pollution has further increased acidity in receiving waters in some regions of the country and may be the cause of some observed amphibian declines (Dunson and others, 1992). Historically, acidic precipitation has been particularly problematic the northeastern United States where regional rainfall $\mathrm{pH}$ values frequently fall below 4.0 , and the average $\mathrm{pH}$ of rainfall in the area around DEWA in 2001 was about 4.3.

It is difficult to prove the relative contributions of natural and anthropogenic sources of acidity to aquatic habitats, and no attempt is made to attribute the failure of ambystomatid salamanders to breed in sites with lower $\mathrm{pH}$ to acid rain. However, acid rain and acid deposition continue to be a problem in the region (Driscoll and others, 2016), and consequently, it is plausible that the salamander breeding ponds could become increasingly acidic in the future, possibly compromising population viability, if it has not already. Thus, the investigators believe DEWA managers may want to consider monitoring $\mathrm{pH}$ in selected wetland sites as part of their long-term monitoring program.

Although the results of this study provide a wealth of information about the status and recent trends of this group of species, there are important questions that remain unanswered, especially regarding the status and likelihood of persistence of A. jeffersonianum. For example, why $A$. jeffersonianum is so rare in the Park, and why their breeding sites and reproductive output is so clustered in the Kittitiny Camp area, is unclear. Data from this study indicate that habitat alone does not explain these observations, at least those habitat attributes that were measured. Comparison of results from this study with those obtained in earlier surveys indicates that, although rare, $A$. jeffersonianum may be as abundant now as in years past. Nevertheless, there remains considerable uncertainty regarding factors that regulate $A$. jeffersonianum populations, and consequently, strategies for their preservation remain ambiguous. In addition, the ecological relation between A. jeffersonianum and LJJ triploid populations is also not well understood. The ecological mechanisms for, and the long-term effects of, their coexistence are not clear from the literature or from this study's data. Thus, additional research including long-term monitoring of population genetics and recruitment patterns may be needed to better inform DEWA management.

Finally, one of the main impetuses for this study was related to the management of small impoundments in the Park. Specifically, there were questions about whether management plans to eliminate or cease maintenance on many of these dams might have negative biological consequences by eliminating breeding habitats of ambystomatid salamanders. Results of this study indicate that artificial impoundments may not provide significant habitat for ambystomatid salamanders. A. jeffersonianum and $A$. opacum almost never bred in artificial impoundments, and although $A$. maculatum used impoundments to breed, it was rarely in significant numbers and usually only when fish were absent. Even during the severe 2002 drought when a much smaller amount of natural breeding habitat was available, none of the three species increased their use of artificial impoundments. These patterns combined with the large amount of naturally occurring wetlands, swamps, and temporary ponds lead to the conclusion that plans to eliminate impoundments will have little effect on pond-breeding salamanders.

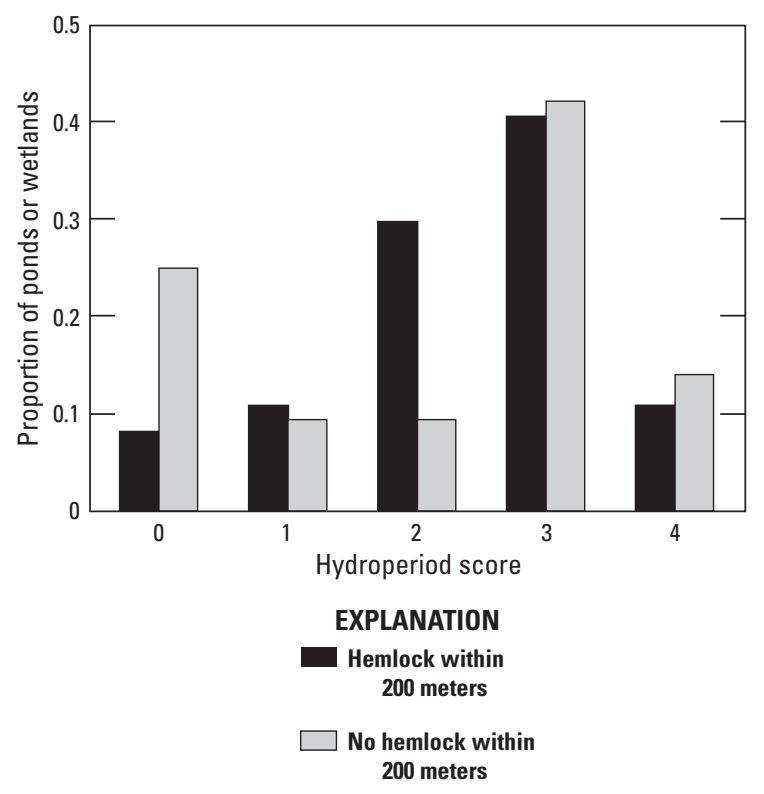

Figure 21. Proportion of ponds with hemlock and without hemlock within 200-m buffers in relation to hydroperiod score, Delaware Water Gap National Recreation Ares. Hemlock presence or absence was inferred from the vegetation map of Myers and Irish (1981).

\section{Summary}

A 3-year study of ambystomatid salamander breeding habits and habitats in the Delaware Water Gap National Recreation Area (DEWA) was conducted by the U.S. Geological Survey, in cooperation with the National Park Service. The objectives of the study were to document the population status and critical breeding habitats of the three species of ambystomatid salamanders known to be present in the DEWA-Ambystoma maculatum (spotted salamander), A. opacum (marbled salamander), and A. jeffersonianum (Jefferson salamander). DEWA managers are interested in ecological information on these species for several reasons. First, at the time the study began, there was little known regarding the status of pond-breeding amphibians and 
their habitats in the DEWA. Second, because they require undegraded habitats in both terrestrial and aquatic habitats to successfully complete their life cycles, the status of ambystomatid salamanders is widely viewed as indicative of overall ecosystem health. Third, because ambystomatid salamanders and other pond-breeding amphibians have been observed in numerous artificial impoundments within DEWA, park managers wanted to assess whether dismantling or discontinuing maintenance of artificial impoundments would pond-breeding amphibians and possibly other species that use pond or wetland habitats in the Park.

In 2001, 2002, and 2003, the size and location of 200 wetlands, ponds, artificial impoundments, and related landscape positions (Ridge versus Valley; Pennsylvania side versus New Jersey side of the river) were mapped, and site habitat data relating to salamander occurrence and abundance patterns were collected. The data collected during this study provide important new baseline information on ambystomatid salamanders and wetland habitats in the DEWA that will enhance long-term inventory and monitoring efforts. In addition, breeding habitat assessments indicate that ambystomatid salamanders may be sensitive to a wide variety of stresses important in the DEWA and in the region. In particular, recent trends in development (for example, roads) in and near the DEWA, regional increases in the acidity of precipitation, and predicted long-term warming trends for the region could be detrimental to pond-breeding salamander populations because of their effects on breeding site quality and quantity, and on the integrity of migration corridors. In contrast, the results of the study suggest that eliminating small impoudments are unlikely to adversely affect salamaners.

\section{References Cited}

Blaustein, A.R., and Wake, D.B., 1990, Declining amphibian populations-A global phenomenon?: Trends in Ecology \& Evolution, v. 5, no. 7, p. 203-204 https://doi.org/10.1016/ 0169-5347(90)90129-2.

Blaustein, A.R., Edmond, B., Kiesecker, J.M., Beatty, J.J., and Hokit, D.G., 1995, Ambient ultraviolet radiation causes mortality in salamander eggs: Ecological Applications, v. 5, no. 3, p. 740-743 https://doi.org/10.2307/1941981.

Bogart, J.P., and Lecht, L.E., 1987, Evidence for the requirement of sperm in unisexual salamander hybrids (genus Ambystoma): Canadian Field Naturalist, v. 101, p. 434-436.

Beebee, T.J.C., 1997, Changes in dewpond numbers and amphibian diversity over 20 years on chalk downland in Sussex, England: Biological Conservation, v. 81 , no. 3, p. 215-219 https://doi.org/10.1016/S00063207(97)00002-5.
Beebee, T.J.C., and Rowe, G., 2001, Application of genetic bottleneck testing to the investigation of amphibian declines-A case study with Natterjack toads: Conservation Biology, v. 15, no. 1, p. 266-270 https://doi.org/10.1111/ j.1523-1739.2001.99438.x.

Bishop, S.C., 1941, The salamanders of New York: New York State Museum Bulletin 324, p. 1-356.

Bowden, J.D., and Bauerle, W.L., 2008, Measuring and modeling the variation in species-specific transpiration in termperate deciduous hardwoods: Tree Physiology, v. 28, p. 1675-1683.

Breiman, L., Friedman, J.H., Olshen, R.A., and Stone, C.J., 1984, Classification and regression trees, The Wadsworth statistics/probability series-New York: New York, Chapman and Hall, Inc., p. 358.

Brodman, R., 1995, Annual variation in breeding success of two syntopic species of Ambystoma salamanders: Journal of Herpetology, v. 29, p. 111-113.

Bury, R.B., Corn, P.S., Dodd, C.K., McDiarmid, R.W., and Scott, N.J., 1995, Amphibians, in Laroe, E.T., Farris, G.S., Puckett, C.E., Doran, P.D., and Mac, M.J., eds., Our Living Resources: Washington, D.C., U.S. Department of the Interior, National Biolgogical Service, p. 124-126.

Bunnell, J.F., and Zampella, R.A., 1999, Acid water anuran pond communities along a regional forest to agro-urban ecotone: Copeia, v. 1999, no. 3, p. 614-627. https://doi.org/ 10.2307/1447594.

Burton, T.M., and Likens, G.E., 1975, Salamander populations and biomass in the Hubbard Brook experimental forest, New Hampshire: Copeia, v. 1975, no. 3, p. 541-546. https://doi.org/10.2307/1443655.

Carey, C., and Alexander, M.A., 2003, Climate change and amphibian declines: Diversity \& Distributions, v. 9, no. 2, p. 111-121 https://doi.org/10.1046/j.14724642.2003.00011.x.

Conant, R., and Collins, J.T., 1998, A Field Guide to Reptiles and Amphibians of eastern and central North America: Boston, Mass., Houghton Mifflin Company, p. 616.

Cook, R.P., 1983, Effects of acid precipitation on embryonic mortality of Ambystoma salamanders in the Connecticut Valley of Massachusetts: Biological Conservation, v. 27, no. 1, p. 77-88 https://doi.org/10.1016/00063207(83)90007-1.

Corn, P.S., Adams, M.J., Battaglia, W.A., Gallant, A.L., James, D.L., Knutson, M., Langtimm, C.A., and Sauer, J.R., 2005, Amphibian research and monitoring initiative-Concepts and implementation: U.S. Geological Survey Scientific Investigations Report 2005-5015, p. 23. 
Cornwall Center for Metropolitan Studies, 2003, Data set: Rutgers University. accessed July 19, 2019, at https://www.cornwall.rutgers.edu/DataSets.htm

Cowardin, L.M., Carter, V., Golet, F.C., and LaRoe, E.T., 1979, Classification of wetlands and deepwater habitats of the United States: Washington, D.C., U.S. Department of the Interior, Fish and Wildlife Service, 131 p.

Davic, R.D., and Welsh, H.H., Jr., 2004, On the ecological role of salamanders: Annual Review of Ecology Evolution and Systematics, v. 35, no. 1, p. 405-434.

De'ath, G., and Fabricius, K.E., 2000, Classification and regression trees-A powerful yet simple technique for ecological data analysis: Ecology, v. 81, no. 11, p. 3178-3192 https://doi.org/10.1890/00129658(2000)081[3178:CARTAP]2.0.CO\&\#x003B;2.

Dodd, C.K., Jr., and Cade, B.S., 1998, Movement patterns and the conservation of breeding amphibians in small, temporary wetlands: Conservation Biology, v. 12, p. 331-339 https://doi.org/10.1046/j.15231739.1998.97183.x.

Downs, F.L., 1989, Family Ambystomatidae, in Pfingsten, R.A., and Downs, F.L., eds., Athens, Ohio, College of Biological Sciences, Salamanders of Ohio-Ohio Bulletin v. 7. New Series, p. 87-172.

Driscoll, C.T., Driscoll, K.M., Fakhraei, H., and Civerolo, K., 2016, Long-term temporal trends and spatial patterns in the acid-base chemistry of lakes in the Adirondack region of New York in response to decreases in acidic deposition: Atmospheric Environment, v. 146, p. 5-14 https://doi.org/ 10.1016/j.atmosenv.2016.08.034.

Dunson, W.A., Wyman, R.L., and Corbett, E.S., 1992, A symposium on amphibian declines and habitat acidification: Journal of Herpetology, v. 26, no. 4, p. 349-352 https://doi.org/10.2307/1565110.

Evans, R.A., 1995, Hemlock ravines at Delaware Water Gap National Recreation Area: highly valued, distinctive and threatened ecosystems, in Delaware Water Gap National Recreation Area 30th Anniversary symposium: National Park Service, Delaware Water Gap National Recreation Area.

Fahrig, L., Pedlar, J.H., Pope, S.E., Taylor, P.D., and Wegner, J.F., 1995, Effect of road traffic on amphibian density: Biological Conservation, v. 73, p. 177-182.

Freda, J., 1985, Temporary ponds of the Delaware Water Gap National Recreation Area: Pennsylvania State University, Master's Thesis.
Freda, J., 1986, The influence of acidic pond water on amphibians: Water, Air, and Soil Pollution, v. 30, no. 1-2, p. 439-450 https://doi.org/10.1007/BF00305213.

Freda, J., Sadinski, W.J., and Dunson, W.A., 1991, Longterm monitoring of amphibian populations with respect to the effects of acidic deposition: Water, Air, and Soil Pollution, v. 55, no. 3-4, p. 445-462 https://doi.org/10.1007/ BF00211205.

Gibbs, J.P., 2000, Wetland loss and biodiversity conservation: Conservation Biology, v. 14, no. 1, p. 314-317 https://doi.org/10.1046/j.1523-1739.2000.98608.x.

Hairston, N.G., 1987, Community ecology and salamander guilds: New York, Cambridge University Press, 230 p.

Hansen, J., Fung, I., Lacis, A., Rind, D., Lebedeff, S., Ruedy, R., Russell, G., and Stone, P., 1988, Global climate changes as forecast by Goddard Institute for Space Studies three-dimensional model: Journal of Geophysical Research, v. 93, D8, p. 9341-9364 https://doi.org/10.1029/ JD093iD08p09341.

High, K.B., 1999, Delaware Water Gap N.R.A: Freshwater Wetlands, Digital map data, accessed April 20, 2005, at https://www.nps.gov/gis/metadata/dewa/dwetland.html

Hopey, M.E., and Petranka, J.W., 1994, Restriction of wood frogs to fish-free habitats-How important is adult choice?: Copeia, v. 4, no. 4, p. 1023-1025 https://doi.org/ $10.2307 / 1446726$.

Horne, M.T., and Dunson, W.A., 1995, The interactive effects of low $\mathrm{pH}$, toxic metals, and DOC on a simulated temporary pond community: Environmental Pollution, v. 89, no. 2, p. 155-161 https://doi.org/10.1016/0269-7491(94)00057-K.

Houlahan, J.E., and Findlay, C.S., 2003, The effects of adjacent land use on wetland amphibian species richness and community composition: Canadian Journal of Fisheries and Aquatic Sciences, v. 60, no. 9, p. 1078-1094 https://doi.org/ 10.1139/f03-095.

Hosmer, D.W., and Lemeshow, S., 1989, Applied Logistic Regression: New York, John Wiley and Sons, p. 375.

Hulse, A.C., McCoy, C.J., and Censky, E.J., 2001, Amphibians and Reptiles of Pennsylvania and the Northeast: Ithica, N.Y., Cornell University Press, 419 p.

Jenkins, C.L., McGarigal, K., and Gamble, L.R., 2002, A comparison of aquatic sampling techniques used to sample Ambystoma opacum larvae: Journal of Herpetology, v. 33, p. 33-35.

Julian, J.T., 2000, Colonization of an artificial wetland by amphibians at Rocky Gap State Park, Maryland: Frostburg, Md., Frostburg State University, Masters thesis, $94 \mathrm{p}$. 
Julian, S.E., King, T.L., and Savage, W.K., 2003, Novel Jefferson salamander, Ambystoma jeffersonianum, microsatellite DNA markers detect population structure and hybrid complexes: Molecular Ecology Notes, v. 3, no. 1, p. 95-97 https://doi.org/10.1046/j.1471-8286.2003.00362.x.

Kolozsvary, M.B., and Swihart, R.K., 1999, Habitat fragmentation and the distribution of amphibians - Patch and landscape correlates in farmland: Canadian Journal of Zoology, v. 77, no. 8, p. 1288-1299 https://doi.org/10.1139/z99-102.

Kutka, F.J., 1994, Low pH effects on swimming activity of Ambystoma salamander larvae: Environmental Toxicology and Chemistry, v. 13, no. 11, p. 1821-1824 https://doi.org/ 10.1002/etc.5620131114.

Laan, R., and Verboom, B., 1990, Effects of pool size and isolation of amphibian communities: Biological Conservation, v. 54, no. 3, p. 251-262 https://doi.org/10.1016/00063207(90)90055-T.

Lehtinen, R.M., Galatowitsch, S.M., and Tester, J.R., 1999, Consequences of habitat loss and fragmentation for wetland amphibian assemblages: Wetlands, v. 19, no. 1, p. 1-12 https://doi.org/10.1007/BF03161728.

McCullagh, P., 1980, Regression models for ordinal data (with discussion): Journal of the Royal Statistical Society. Series B. Methodological, v. 42, no. 2, p. 109-127 https://doi.org/ 10.1111/j.2517-6161.1980.tb01109.x.

Monello, R.J., and Wright, R.G., 1999, Amphibian habitat preferences among artificial ponds in the Palouse region of northern Idaho: Journal of Herpetology, v. 33, no. 2, p. 298-303 https://doi.org/10.2307/1565727.

Muths, E., Corn, P.S., Perrier, A.P., and Green, D.E., 2003, Evidence for disease-related amphibian declines in Colorado: Biological Conservation, v. 110, no. 3, p. 357-365 https://doi.org/10.1016/S00063207(02)00239-2.

Myers, W.L., and Irish, R.R., 1981, Vegetation survey of Delaware Water Gap National Recreation Area-Final Report: U.S. Department of Interior National Park Service. Mid-Atlantic Region.

Nyman, S., 1979, The larval ecology, breeding migrations, and distribution of Ambystoma jeffersonianum, Ambystoma platineum, and Ambystoma maculatum in northern New Jersey: New Brunswick, N.J., Rutgers University, Master's Thesis.

Nyman, S., Ryan, M.J., and Anderson, J.D., 1988, The distribution of the Ambystoma jeffersonianum complex in New Jersey: Journal of Herpetology, v. 22, no. 2, p. 224-228 https://doi.org/10.2307/1564002.
Paton, P.W., and Crouch, W.B., III, 2002, Using phenology of pond-breeding amphibians to develop conservation strategies: Conservation Biology, v. 16, no. 1, p. 194-204 https://doi.org/10.1046/j.1523-1739.2002.00260.x.

Pennsylvania State Data Center, 2020, accessed September 19, 2019, at https://pasdc.hbg.psu.edu/Data

Pechmann, J.H.K., Scott, D.E., Gibbons, J.W., and Semlitsch, R.D., 1989, Influence of wetland hydroperiod on diversity and abundance of metamorphosing juvenile amphibians: Wetlands Ecology and Management, v. 1, no. 1, p. 3-11 https://doi.org/10.1007/BF00177885.

Petranka, J.W., 1998, Salamanders of the United States and Canada: Washington, D.C., Smithsonian Institution Press, $592 \mathrm{p}$.

Pounds, J.A., 2001, Climate and amphibian declines: Nature, v. 410 , no. 6829 , p. $639-640$ https://doi.org/10.1038/ 35070683 .

Portnoy, J.W., 1990, Breeding biology of the spotted salamander Ambystoma maculatum (Shaw) in acidic temporary ponds at Cape Cod, USA: Biological Conservation, v. 53, no. 1, p. 61-75 https://doi.org/10.1016/0006-3207(90)90063-U.

Resetarits, W.J., Jr., and Wilbur, H.M., 1991, Calling site choice by Hyla chrysoscelis-Effects of predators, competitors, and oviposition sites: Ecology, v. 72, no. 3, p. 778-786 https://doi.org/10.2307/1940580.

Rowe, C.L., and Dunson, W.A., 1993, Relationships among abiotic parameters and breeding effort by three amphibians in temporary wetlands of central Pennsylvania: Wetlands, v. 13, no. 4, p. 237-246 https://doi.org/10.1007/BF03161290.

Rowe, C.L., and Dunson, W.A., 1995, Impacts of hydroperiod on growth and survival of larval amphibians in temporary ponds of central Pennsylvania, USA: Oecologia, v. 102, no. 4, p. 397-403 https://doi.org/10.1007/BF00341351.

Sadinski, W.J., and Dunson, W.A., 1992, A multilevel study of effects of low $\mathrm{pH}$ on amphibians of temporary ponds: Journal of Herpetology, v. 26, no. 4, p. 413-422 https://doi.org/10.2307/1565117.

Semlitsch, R.D., 1987, Paedomorphosis in Ambystoma talpoideum - Effects of density, food, and pond drying: Ecology, v. 68, no. 4, p. 994-1002 https://doi.org/ $10.2307 / 1938370$.

Semlitsch, R.D., 2000, Principals for management of aquaticbreeding amphibians: The Journal of Wildlife Management, v. 64, no. 3, p. 615-631 https://doi.org/10.2307/3802732.

Semlitsch, R.D., 1988, Allotopic distributions of two salamanders-Effects of fish predation and competitive interactions: Copeia, v. 2, no. 2, p. 290-298 https://doi.org/ 10.2307/1445868. 
Skelly, D.K., 2001, Distributions of pond-breeding anuransAn overview of mechanisms: Israel Journal of Zoology, v. 47, no. 4, p. 313-332 https://doi.org/10.1560/BVT1LUYF-2XG6-B007.

Snodgrass, W.J., Komoroski, J.M., Bryan, L.A., Jr., and Burger, J., 2000, Relationships among isolated wetland size, hydroperiod, and amphibian species richnessImplications for wetland regulations: Conservation Biology, v. 14, no. 2, p. 414-419 https://doi.org/10.1046/j.15231739.2000.99161.x.

Snyder, C.D., Young, J.A., Lemarie, D.P., and Smith, D.R., 2002, Influence of eastern hemlock (Tsuga canadensis) forests on aquatic invertebrate assemblages in headwater streams: Canadian Journal of Fisheries and Aquatic Sciences, v. 59, no. 2, p. 262-275 https://doi.org/ 10.1139/f02-003.

Snyder, C.D., and Young, J.A., 2019, Ambystomatid salamander population and breeding pond habitat data for the Delaware Water Gap National Recreation Area (2001-2003): U.S. Geological Survey data release, https://doi.org/10.5066/P9XCVHY3.

Urban, D.L., 2002, Classification and Regression Trees, in McCune, B., and Grace, J.B., eds., Analysis of Ecological Communities: Gleneden Beach, Ore., MjM Software Design, p. 222-232.
Vayssiêres, M.P., Plant, R.E., and Allen-diaz, B.H., 2000, Classification trees-An alternative non-parametric approach for predicting species distributions: Journal of Vegetation Science, v. 11, no. 5, p. 679-694 https://doi.org/ $10.2307 / 3236575$.

Vitt, L.J., Caldwell, J.P., Wilbur, H.M., and Smith, D.C., 1990, Amphibians as harbingers of decay: Bioscience, v. 40, no. 6, 418 p., https://doi.org/10.1093/bioscience/40.6.418.

Welsh, H.H., and Ollivier, L.M., 1998, Stream amphibians as indicators of ecosystem stress-A case study from California's Redwoods: Ecological Applications, v. 8, no. 4, p. 1118-1132, https://doi.org/10.2307/2640966.

Werner, E.E., Wellborn, G.A., and Mcpeek, M.A., 1995, Diet composition in postmetamorphic bullfrogs and green frogs-Implications for interspecific predation and competition: Journal of Herpetology, v. 29, no. 4, p. 600-607, https://doi.org/10.2307/1564744.

Wetherald, R.T., and Manabe, S., 1988, Cloud feedback processes in a general circulation model: Journal of the Atmospheric Sciences, v. 45, no. 8, p. 1397-1416 https://doi.org/10.1175/1520-0469(1988)045\&\#x003C; 1397:CFPIAG\&\#x003E;2.0.CO\&\#x003B;2.

Wyman, R.L., 1990, What's happening to the amphibians?: Conservation Biology, v. 4, no. 4, p. 350-352 https://doi.org/10.1111/j.1523-1739.1990.tb00307.x.
For more information, contact:

Leetown Science Center

11649 Leetown Road

Kearneysville, WV 25430

https://www.usgs.gov/centers/lsc

Publishing support provided by the

West Trenton and Reston Publishing Service Centers 


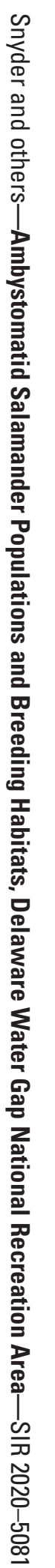

